\title{
22. CENOZOIC MARINE PLANKTONIC DIATOM STRATIGRAPHY OF THE TROPICAL INDIAN OCEAN
}

\author{
Hans-Joachim Schrader, Geologisch-Palantologisches Institut und Museum der
}

Universität Kiel, F.R. Germany Kiel, Germany

\section{CONTENTS}

Introduction . . . . . . . . . . . . . . 887

Preparation of samples $\ldots \ldots \ldots \ldots \ldots \ldots \ldots 887$

Time ranges of taxa and biostratigraphic zonation ...888

Epoch and age boundaries ............... 894

Geochronological time scale .............. 894

Correlation to other diatom sections $\ldots \ldots \ldots \ldots 895$

Diatoms at each site ................... 896

Site $236 \ldots \ldots \ldots \ldots \ldots \ldots \ldots \ldots \ldots$

Site $238 \ldots \ldots \ldots \ldots \ldots \ldots \ldots \ldots \ldots 6 \ldots$

\section{INTRODUCTION}

Leg 22 of the Deep Sea Drilling Project, January-March 1972, from Darwin, Australia to Colombo, Ceylon drilled eight sites. Two sites, 213 and 215 , contain excellently preserved Cenozoic diatom assemblages. Site 213 is situated east of the Ninetyeast Ridge at lat $10^{\circ} 12.71^{\prime} \mathrm{S}$, long $93^{\circ} 53.77^{\prime} \mathrm{E}$ and was drilled at a water depth of 5611 meters. Site 215 is situated west of the Ninetyeast Ridge at lat $8^{\circ} 07.30^{\prime} \mathrm{S}$, long $86^{\circ} 47.50^{\prime} \mathrm{E}$ and was drilled at a water depth of 5319 meters. Leg 24 of the Deep Sea Drilling Project, May-June 1972, from Djibouti, F.T.A.I. to Port Louis, Mauritius drilled eight sites. Two sites, 236 and 238, were chosen for this investigation. Site 236 is situated northeast of Seychelles Block at lat $01^{\circ} 40.62^{\prime} \mathrm{S}$, long $57^{\circ} 38.85^{\prime} \mathrm{S}$ and was drilled at a water depth of 5404 meters. Site 238 is situated at the extreme northeast end of Argo Fracture Zone at lat $11^{\circ} 09.21^{\prime} \mathrm{S}$, long $70^{\circ} 31.56^{\prime} \mathrm{E}$ and was drilled at an actual water depth of 2844 meters (Figure 1). Sites 236, 238,215 , and 213 today underlie areas where the calculated mean yearly primary production (expressed as $\mathrm{gC} / \mathrm{m}^{2} /$ year) varies between 100 and $200 \mathrm{gC} / \mathrm{m}^{2} /$ year (Krey, 1971) (Figure 2).

\section{PREPARATION OF SAMPLES}

The total amount of the wet samples (approx. $3 \mathrm{ml}$ of original samples) was taken and heated at $100^{\circ} \mathrm{C}$ for 20 minutes in a beaker with an equal mixture of concentrated acetic acid and hydrogen peroxide. The suspension was then centrifuged in $50 \mathrm{ml}$ centrifuge tubes at a speed of 1300 r.p.m., decanted, and the residue diluted with demineralized water. This procedure of centrifugingdecanting-diluting was repeated for five times to remove most of the clay-sized mineral components. The residue was then carefully shaken in a mixture of 0.5 percent sodium pyrophosphate in water and centrifuged twice at 1300 r.p.m. The residue was then washed three times by repeated centrifuging, decanting, and diluting. Residue, after the
Site 213 (DSDP Leg 22) ................ 899

Site 215 (DSDP Leg 23) . . . . . . . . . . . . 899

Systematic section, floral sequence . ......... 908 "Events" for establishing biostratigraphic zonation . . 917 Ethmodiscus ooze interpretation ............. 919 Acknowledgments ................... 920 References ........................ 920 Plates with explanations $\ldots \ldots \ldots \ldots \ldots \ldots \ldots . \ldots 24$

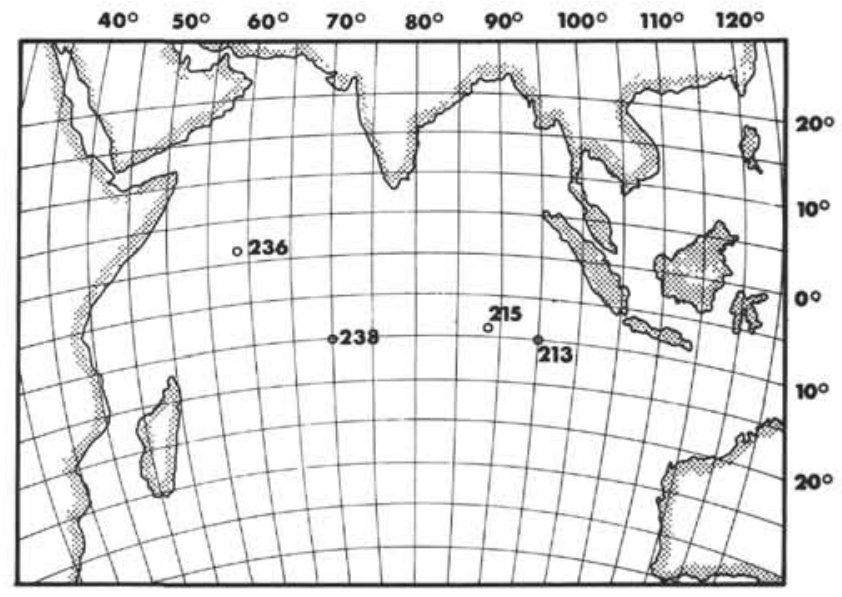

Figure 1. Index map, showing localities of investigated sites of Leg 22 and Leg 24.

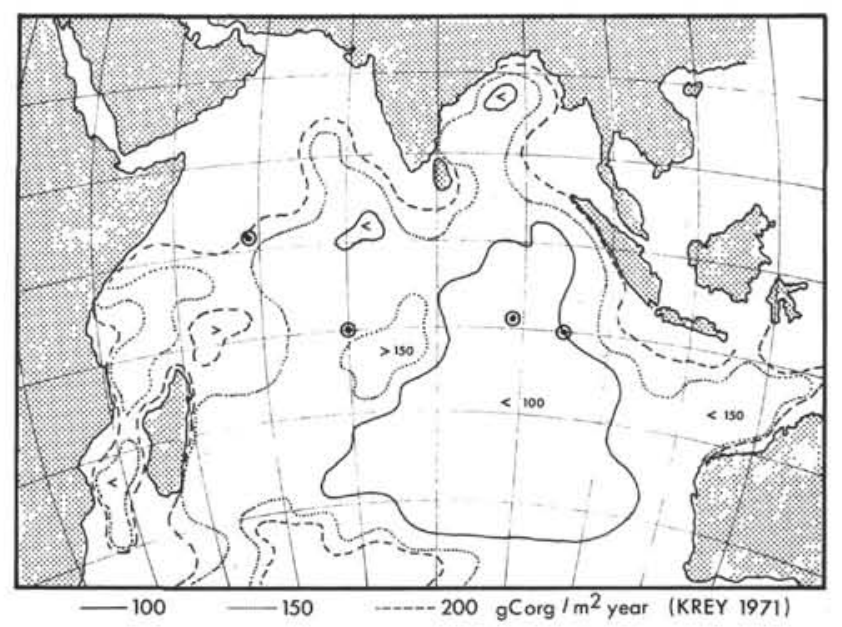

Figure 2. Mean calculated organic carbon production per year in the Indian Ocean. Dots represent sites (Krey, 1971). 
cleaning procedure, was stored in demineralized water to which a few drops of formaldehyde had been added to prevent bacterial activity (Schrader, in press).

For slide preparation, each sample was carefully shaken and 1 to 3 drops of residue were pipetted from the middle of the bottle (plastic disposable tips, Stradner and Papp, 1961) and placed on a clean $18 \times 18 \mathrm{~mm}$ cover glass (thickness less than $0.17 \mathrm{~mm}$ ). After drying, a small amount of Aroclor No. 4465 (nd 1.66; Xylene solvent, Schrader, 1969) was placed on the cover glass and heated at approximately $100^{\circ} \mathrm{C}$ until the mounting medium became hard upon cooling. The cover glass was then taken up on a heated slide (for more detailed description see Hustedt, 1924; Schrader, 1973a, 1974).

Investigations were made with a Leitz Orthoplan light microscope with apochromatic optics (Objectives FL Oil 54 X/0.95 and Apo Oil 90 X/1.40). Micrographs were made with an automatic Leitz Orthomat camera using a $10 \mathrm{X}$ ocular. Most of the illustrated individuals are located on the slides and marked with a diamond microscopical pencil. Individuals on the plates are pictured at $1500 \mathrm{X}$ magnification except for a few at $600 \times$ magnification.

\section{TIME RANGES OF TAXA AND BIOSTRATIGRAPHIC ZONATION}

Planktonic marine diatom zonations of the equatorial Pacific were first established by Kolbe (1954) on sediment cores of the Swedish Deep-Sea Expedition. This zonation has been revised by Kanaya (1969 and 1971) who showed that the Pliocene/Pleistocene boundary of Kolbe (1954) on SDE Core 76 is really an erosional unconformity. Muchina (1963) discussed the diatom stratigraphy on Station 3802 and defined four zones. In a later paper, Muchina (1969) reported on additional cores from the Pacific and constructed a range chart of stratigraphically useful diatoms for the Neogene. Burckle (1972) suggests that a late Miocene-early Pliocene unconformity is present in the core of Muchina (1969). Bukry and Foster (1973) established a diatom zonation from Holocene to middle Miocene using a $44 \mu$ fraction. Zonations with high biostratigraphic resolution were presented by Burckle (1972) for the equatorial east Pacific, by Jousé (1971b) for the central north Pacific, by Schrader (1973a) for the northeast Pacific, by Koizumi (1973) for the northwest Pacific, by Kanaya and Koizumi (1970) for the circum-Pacific region. The last range chart presents preliminary data which will be revised in the near future (Koizumi, 1973, personal communication).

The biostratigraphic zonation used in this report incorporates biostratigraphic zones first proposed by Burckle (in Hays et al., 1969) and Burckle (1972). The biostratigraphic zonation of Burckle (1972) is related to closely spaced first and last occurrences of species and to the composition of the thanatocoenoses. The diatom zonation applicable to the Leg 22 and Leg 24 sequences is correlatable to the zonation of Burckle (1972) except for the closer distance (in time) (Figure 3) of the new proposed tropical Indian Ocean diatom zones (Figure 4). New "events", morphotypic and evolutionary, were found and defined, and different taxonomic views led to a different evolutionary interpretation and thus different biostratigraphic zonation.

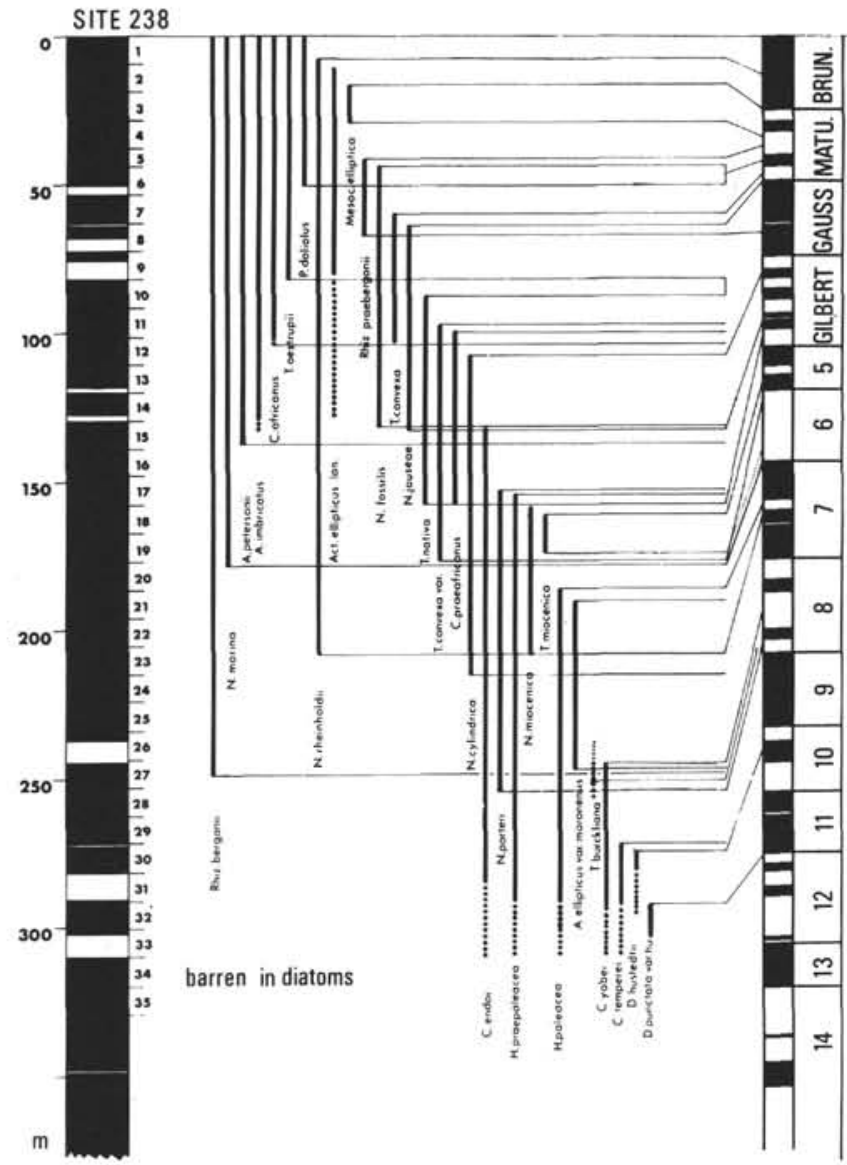

Figure 3. Species ranges at Site 238. Left: Site 238, recovered interval black, core numbers. Right: species ranges correlated to the paleomagnetic stratigraphic scale. For explanation see text.

\section{Tropical Indian Ocean Diatom Zone 1}

Definition: The base of this zone is defined at the extinction of Nitzschia reinholdii.

Discussion: An essentially modern flora is present throughout the zone, it includes Actinocyclus ehrengergii, Asteromphalus arachne, A. flabellatus, A. imbricatus, A. petersonii, A. robustus, Coscinodiscus africanus, $C$. curvatulus, $C$. crenulatus, $C$. excentricus, $C$. lineatus, C. lineatus var. ellipticus, C. nodulifer, Ethmodiscus rex, Hemidiscus cuneiformis, Nitzschia aequatorialis, $N$. marina, $N$. seriata, $N$. interrupta, Pseudoeunotia doliolus, Roperia tesselata and varieties, Rhizosolenia bergonii, Rh. styliformis, Thalassiosira excentrica, Th. oestrupii, Thalassionema nitzschioides, Thalassiothrix frauenfeldii, Th. longissima, and Triceratium cinnamomeum.

Paleomagnetic stratigraphy: The base of this zone falls within the middle part of the Brunhes normal epoch and ranges to the top of the Brunhes normal epoch.

Comparison with the zonation of other workers: Zone 1 correlates to the upper part of the Pseudoeunotia doliolus Range Zone of Burckle (1972), and with the upper part of the Roperia tesselata Zone of Bukry and Foster (1973). 


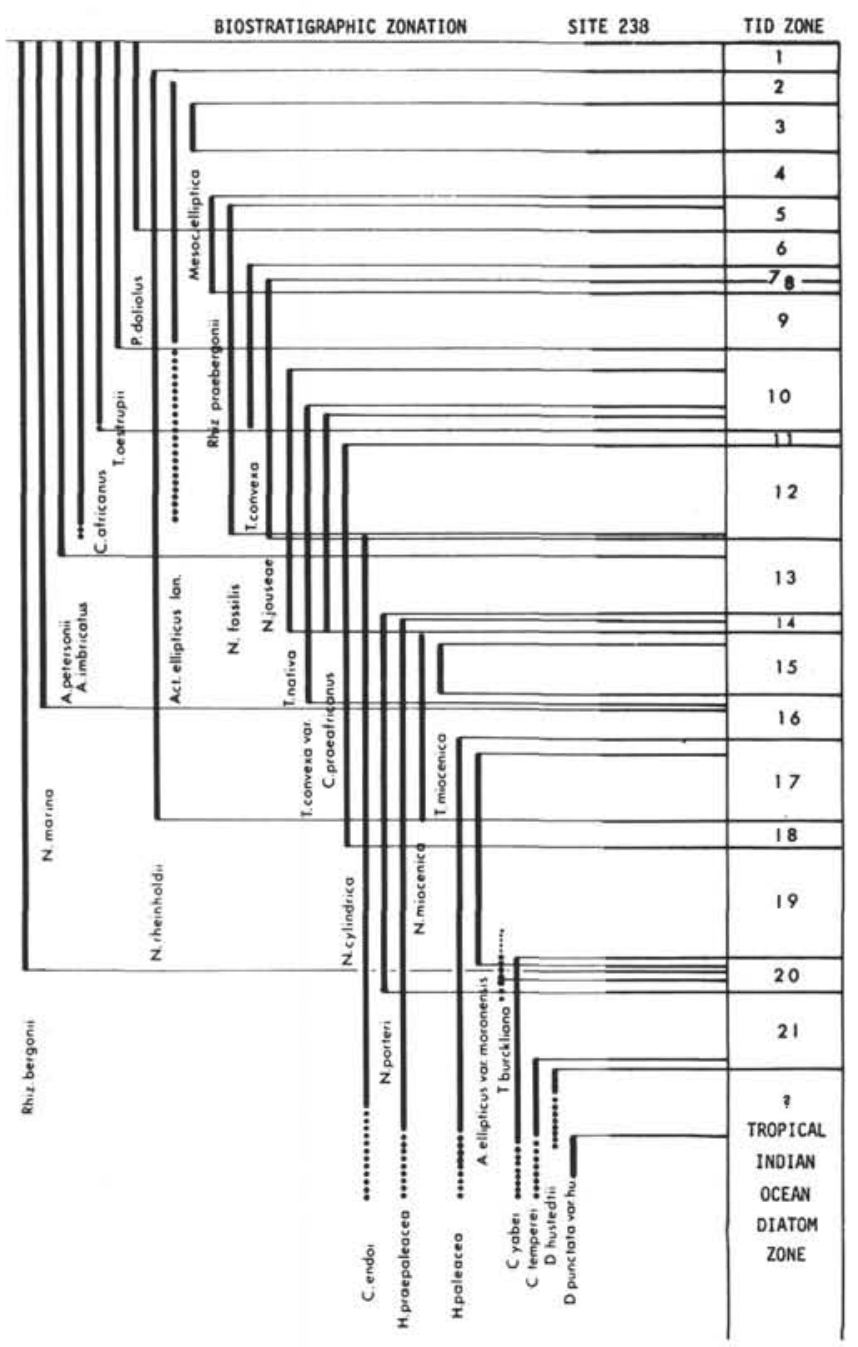

Figure 4. Species ranges and resulting tropical Indian Ocean diatom zonation.

Absolute age: 0.3 (?) m.y., the lower age has been interpolated from the data of Kanaya and Koizumi (1970) and Kanaya in Kobayashi et al. (1971).

Geographical extent: Found in tropical Indian Ocean sediments.

Type locality: DSDP Leg 24, Site 238, Core 1, Section 1, $60 \mathrm{~cm}$ to Core 1 , Section $3,75 \mathrm{~cm}$.

\section{Tropical Indian Ocean Diatom Zone 2}

Definition: The base of this zone is placed at the extinction of the silicoflagellate species Mesocena elliptica within the Pleistocene; the top at the extinction of Nitzschia reinholdii.

Discussion: A modern flora, present throughout the zone includes the same species as Tropical Indian Ocean Diatom Zone 2.

Paleomagnetic stratigraphy: The base of this Zone falls within the uppermost part of the Matuyama reversed epoch; the top within the middle part of the Brunhes normal epoch.

Comparison with the zonation of other workers: Zone 2 correlates to the upper part of the Pseudoeunotia doliolus Range Zone of Burckle (1972), with the upper part of the Roperia tesselata Zone of Bukry and Foster (1973) and the Dictyocha epiodon Zone of Bukry and Foster (1973).

Absolute age: 0.3(?)-0.7 m.y.

Geographical extent: Found in tropical Indian and Pacific Ocean sediments.

Type locality: DSDP Leg 24, Site 238, Core 1, Section 4, $65 \mathrm{~cm}$ to Core 2, Section $2,75 \mathrm{~cm}$.

\section{Tropical Indian Ocean Diatom Zone 3}

Definition: The base of this zone is defined at the first evolutionary appearance within the Pleistocene of the silicoflagellate Mesocena elliptica; the top at the extinction of the silicoflagellate Mesocena elliptica within the Pleistocene.

Discussion: A modern flora is present throughout this zone with a similar species assemblage as Zone 1 .

Paleomagnetic stratigraphy: The base of this zone falls just below the Jaramillo event within the Matuyama reversed epoch; the top within the uppermost part of the Matuyama reversed epoch.

Comparison with the zonation of other workers: Zone 3 correlates to the middle part of the Pseudoeunotia doliolus Range Zone of Bukry and Foster (1973) and to the Mesocena elliptica silicoflagellate zone of Bukry and Foster (1973).

Absolute age: 0.7-0.93 m.y. extrapolated from Burckle in Hays et al. (1969) and from Kanaya in Kobayashi et al. (1971).

Geographical extent: Found in tropical Indian and Pacific Ocean sediments.

Type locality: DSDP Leg 24, Site 238, Core 2, Section 3, $75 \mathrm{~cm}$ to Core 3 , Section $6,75 \mathrm{~cm}$.

\section{Tropical Indian Ocean Diatom Zone 4}

Definition: The base of this zone is defined at the evolutionary extinction of Rhizosolenia praebergonii; the top at the first evolutionary appearance of the silicoflagellate Mesocena elliptica within the Pleistocene.

Discussion: A modern flora in this zone includes Actinocyclus ehrenbergii, $A$. divisus, $A$. ellipticus forma lanceolata, Asterolampra affinis, A. marylandica, Asteromphalus arachne, A. flabellatus, A. heptactis, $A$. imbricatus, Coscinodiscus africanus, $C$. crenulatus, $C$. lineatus, $C$. lineatus var. ellipticus, $C$. nodulifer, $C$. tabularis var. egregius, Ethmodiscus rex, Hemidiscus cuneiformis, Nitzschia marina, $N$. seriata, $N$. reinholdii, Pseudoeunotia doliolus, Roperia tesselata, Rhizosolenia bergonii, Pleurosigma sp., Thalassiosira excentrica, Th. oestrupii, Th. plicata, Thalassionema nitzschioides, Thalassiothrix frauenfeldii, Thal. longissima. Within this zone, Roperia tesselata var. ovata appears as does Coscinodiscus lineatus var. ellipticus. The first occurrences, which are interpretated as being evolutionary, may help to distinguish this zone from others. The first appearance of $C$. lineatus var. ellipticus may be best recognized on coarse fraction slides.

Paleomagnetic stratigraphy: The base of this zone falls within the middle part of the Matuyama reversed epoch; the top just below the Jaramillo event within the Matuyama reversed epoch. 
Comparison with the zonation of other workers: Zone 4 correlates to the middle part of the Pseudoeunotia doliolus Range Zone of Burckle (1972) to the Chaetoceros sp. Zone of Bukry and Foster (1973). Roperia tesselata extends well into this zone.

Absolute age: 0.93 m.y.-1.2 m.y. extrapolated from Kanaya in Kobayashi et al. (1971, fig. 6).

Geographical extent: Found in tropical Indian and Pacific Ocean sediments.

Type locality: DSDP Leg 24, Site 238, Core 4, Section 1, $75 \mathrm{~cm}$ to $4, \mathrm{CC}$.

\section{Tropical Indian Ocean Diatom Zone 5}

Definition: The base of this zone is defined at the first evolutionary appearance of Pseudoeunotia doliolus; the top at the extinction of Rhizosolenia praebergonii.

Discussion: The extinction of Rhizosolenia praebergonii was defined to occur within the middle of the Matuyama reversed epoch by Burckle (1972) and the same range was detected on core $\mathrm{KH}$ 68-4-18 by Kanaya in Kobayashi et al. (1971). The first evolutionary appearance of Pseudoeunotia doliolus from its immediate ancestor was found to occur within the Olduvai event (Burckle, 1972) and at about 5 meters of depth in core KH 68-4-18 (Kanaya in Kobayashi et al., 1971). I have followed Burckle's interpretation although I could find overlapping occurrences of $P$. doliolus and $N$. fossilis. A modern flora is present throughout this zone. Coscinodiscus plicatus occurs last in this zone but is too rare to be considered a useful stratigraphic marker.

Paleomagnetic stratigraphy: The base of this zone falls within the Olduvai event of the Matuyama reversed epoch; the top within the middle part of the Matuyama reversed epoch.

Comparison with the zonation of other workers: Zone 5 correlates to lower part of the Pseudoeunotia doliolus Range Zone of Burckle (1972) and to the North Pacific Diatom Zone IV of Schrader (1973a).

Absolute age: 1.2-1.8 m.y. extrapolated from Burckle (1972), Opdyke (1972), and Berggren (1972).

Geographical extent: Found in tropical Indian Ocean and tropical north Pacific Ocean sediments.

Type locality: DSDP Leg 24, Site 238, Core 5, Section 2, $53 \mathrm{~cm}$ to Core 6 , Section $4,75 \mathrm{~cm}$.

\section{Tropical Indian Ocean Diatom Zone 6}

Definition: The base of this zone is defined at the extinction of Thalassiosira convexa; the top at the first evolutionary appearance of Pseudoeunotia doliolus.

Discussion: The extinction of Thalassiosira convexa occurred in core $\mathrm{KH} 68-4-18$ at approximately 7.8 meters (Kanaya in Kobayashi et al., 1971), which correlates to the lower part of the Matuyama reversed epoch. Burckle (1972) found the same extinction level in equatorial Pacific cores. This species is a warm-water species and does not occur in sediments underlying cold water representing biocoenoses. An essentially modern flora is present comparable to that of Zone 4.

Paleomagnetic stratigraphy: The base of this zone falls within the lower part of the Matuyama reversed epoch, the top within the Olduvai event of the Matuyama reversed epoch.
Comparison with the zonation of other workers: Zone 6 correlates to the upper part of the Rhizosolenia praebergonii Partial-range Zone of Burckle (1972), and to the middle to lower Pleistocene of Muchina (1969).

Absolute age: 1.8-2.1 m.y. extrapolated from Kanaya in Kobayashi et al. (1971).

Geographical extent: Found in tropical Indian and Pacific Ocean sediments.

Type locality: DSDP Leg 24, Site 238, Core 7, Section 1, $75 \mathrm{~cm}$ to Core 7, Section $3,60 \mathrm{~cm}$.

\section{Tropical Indian Ocean Diatom Zone 7}

Definition: The base of this zone has been defined at the extinction of Nitzschia jouseae, the top at the extinction of Thalassiosira convexa.

Discussion: The extinction of Nitzschia jouseae occurs in equatorial Pacific sediments in the uppermost part of the Gauss normal epoch (Burckle, 1972). Other floral elements include Actinocyclus ellipticus, Asterolampra marylandica, Asteromphalus imbricatus, Coscinodiscus africanus, C. lineatus, C. nodulifer, C. plicatus group 4, C. tabularis var. egregius, Ethmodiscus rex, Hemidiscus cuneiformis, Nitzschia fossilis, $N$. interrupta, $N$. marina, $N$. seriata, $N$. reinholdii, Roperia tesselata, Rhizosolenia bergonii, Rhiz. praebergonii, Thalassiosira convexa, Th. excentrica, Th. plicata, Th. symbolophora, Th. oestrupii, Th. sp. II, Th. sp. 7, Thalassionema nitzschioides, Thalassiothrix longissima, and Thal. frauenfeldii.

Paleomagnetic stratigraphy: The base of this zone falls approximately within the uppermost part of the Gauss normal epoch; the top within the lower part of the Matuyama reversed epoch.

Comparison with the zonation of other workers: Zone 7 correlates to the middle part of the Rhizosolenia praebergonii Partial-range Zone of Burckle (1972), Subzone B; with the lower part of the middle Pleistocene of Muchina (1969).

Absolute age: 2.1-2.4 m.y.

Geographical extent: Found in tropical Indian and Pacific Ocean sediments.

Type locality: DSDP Leg 24, Site 238, Core 7, Section 4, $70 \mathrm{~cm}$ to Core 7, Section $5,40 \mathrm{~cm}$.

\section{Tropical Indian Ocean Diatom Zone 8}

Definition: The base of this zone is defined at the first evolutionary appearance of Rhizosolenia praebergonii; the top at the extinction of Nitzschia jouseae.

Discussion: The first appearance of Rhizosolenia praebergonii occurred during the middle of the Gauss normal epoch where Rhiz. praebergonii evolved from its immediate ancestor Rhizosolenia bergonii (Burckle, 1972). Kanaya in Kobayashi et al. (1971) found this event occurring at core $\mathrm{KH} 68-4-20$ at 4.5 meters correlative to the middle normal event which falls between Kaena and the Mammoth events. Other floral elements are comparable to those found in Zone 7.

Paleomagnetic stratigraphy: The base of this zone falls within the middle of the Gauss normal epoch; the top within the uppermost part of the Gauss normal epoch.

Comparison with the zonation of other workers: Zone 8 correlates with the lower part of the Rhizosolenia praebergonii Partial-range Zone of Burckle (1972), 
Subzone A, and with the lower Pleistocene of Muchina (1969).

Absolute age: 2.4-2.85 m.y. extrapolated from Opdyke (1972). Kanaya in Kobayashi et al. (1971) and Burckle (1972).

Geographical extent: Found in tropical Indian and Pacific Ocean sediments.

Type locality: DSDP Leg 24, Site 238, Core 7, Section 6, $35 \mathrm{~cm}$ to Core 8 , Section $2,32 \mathrm{~cm}$.

\section{Tropical Indian Ocean Diatom Zone 9}

Definition: The base of this zone is defined at the first occurrence of Thalassiosira oestrupii; the top at the first evolutionary appearance of Rhizosolenia praebergonii.

Discussion: The morphological differences used to distinguish between Thalassiosira oestrupii and Thalassiosira nativa (in the definition of Burckle, 1972) were made using the following criteria:

1) Thal. oestrupii possesses separated girdles which are solid rings with a solitary spine (compare Plate 1, Figure 14) which is not present in Thal. nativa.

2) The areolae in Thal. oestrupii decrease gradually in size towards the margin, whereas there is a sharp boundary in size in Thal. nativa.

3) The size of the areolae in the middle of the valves of Thal. oestrupii range from 5.8 areolae in $10 \mu$, whereas they range from $9-12$ areolae in $10 \mu$ in Thal. nativa. This species differs from those which I have identified (sensu Sheshukova-Poretzkaya, 1967) which normally did show numerous strutted tubuli in the center of the valve.

Actinocyclus ellipticus forma lanceolata (not var. lanceolata sensu Burckle, 1972) is present in small numbers throughout most of the Pleistocene and Pliocene section. Coscinodiscus africanus ranges in my material well into Zone 10 . The range of Asteromphalus elegans could not be defined because this species was rare in almost all samples (compare to Burckle, 1972, p. 236). Other floral elements are comparable to those found in Zone 7.

Paleomagnetic stratigraphy: The base of this zone has not been defined on the paleomagnetic stratigraphic scale. The top falls within the middle of the Gauss normal epoch.

Comparison with the zonation of other workers: Zone 9 correlates to the upper part of the Nitzschia jouseae Partial-range Zone of Burckle (1972), and to the Pliocene of Muchina (1969).

Absolute age: $2.85-(?)$ m.y. The base has not been defined and no extrapolation is possible at the moment as the first occurrence of Thal. oestrupii has not yet been defined in other sections.

Geographical extent: Found in tropical Indian Ocean sediments.

Type locality: DSDP Leg 24, Site 238, Core 8, Section 3, $35 \mathrm{~cm}$ to Core 9, Section $1,30 \mathrm{~cm}$.

\section{Tropical Indian Ocean Diatom Zone 10}

Definition: The base of this zone has been defined at the first evolutionary appearance of Thalassiosira convexa; the top at the first occurrence of Thalassiosira oestrupii.

Discussion: Thalassiosira convexa first appears at the base of this zone from its immediate ancestor Thal. convexa var. aspinosa. These spines were not broken off (compare to Burckle, 1972, p. 228) in most cases and thus a level could be defined above which spinous forms are common and below which nonspinous forms are common. To determine whether spines are present, high microscopical resolution should be used. Other floral elements are: Actinocyclus divisus, A. ellipticus, Asterolampra grevillei, Ast. imbricatus (first appearance in the upper part of this zone), Coscinodiscus africanus, $C$. crenulatus, $C$. lineatus, $C$. nodulifer, $C$. plicatus group 4, C. tabularis var. egregius, C. vetustissimus (becoming extinct in the lower part of the zone), Ethmodiscus rex, Hemidiscus cuneiformis, $H$. simplicissimus, Nitzschia fossilis, $N$. interrupta, $N$. marina, $N$. praereinholdii (becoming extinct within this zone), $N$. reinholdii, Roperia tesselata (first evolutionary appearance within this zone from its immediate ancestor Roperia praetesselata), Rhizosolenia bergonil, Thalassiosira convexa, Thal. convexa var. aspinosa (becoming extinct in the lower part of the zone), Thal. antarctica, Thal. excentrica, Thal. plicata (first occurrence within the middle of this zone from a not yet defined ancestor), Thal. nativa (becoming extinct within the middle part of this zone), Thal. sp. 7, Thalassionema nitzschioides, Thalassiothrix frauenfeldii, Thal. longissima, and Triceratium cinnamomeum. Muchina (1969, p. 81) lists a Thalassiosira marujamica Sheshuk as being common in her "Pliocene". This species is synonymized with Thalassiosira decipiens (Grun.) Jörg.(?) by SheshukovaPoretzkaya (1967, p. 141). Similar individuals have not been found here; thus a correct interpretation of the range of Thal. marujamica is impossible at the moment.

Paleomagnetic stratigraphy: The zone has not been correlated to the paleomagnetic stratigraphic scale.

Comparison with the zonation of other workers: Zone 10 correlates to the upper part of the Nitzschia jouseae Partial-range Zone of Burckle (1972), to the Pliocene of Muchina (1969).

Absolute age: No absolute age estimates have been made.

Geographical extent: Found in tropical Indian Ocean sediments.

Type locality: DSDP Leg 24, Site 238, Core 9, CC to Core 11 , Section $6,70 \mathrm{~cm}$.

\section{Tropical Indian Ocean Diatom Zone 11}

Definition: The base of this zone has been defined at the extinction of Nitzschia cylindrica; the top at the first evolutionary appearance of Thalassiosira convexa.

Discussion: Nitzschia cylindrica ranges in east equatorial sediments to approximately the middle of the Gilbert reversed epoch. Here a higher range was found, and by comparison with other ranges, an extrapolated range to the "a" event within the Gilbert reversed epoch is postulated. Associated species can be found listed in Table 2

Paleomagnetic stratigraphy: The base of this zone is tentatively placed at the "a" event within the Gilbert reversed epoch; the top has not been defined.

Comparison with the zonation of other workers: Zone 11 correlates with the middle part of the Nitzschia jouseae Partial-range Zone of Burckle (1972) and with the "Pliocene" of Muchina (1969). 
Absolute age: Top has not been estimated, base approximately $3.8 \mathrm{~m} . \mathrm{y}$.

Geographical extent: Found in tropical Indian Ocean sediments.

Type locality: DSDP Leg 24, Site 238, Core $11, \mathrm{CC}$ to Core 12 , Section $3,70 \mathrm{~cm}$.

\section{Tropical Indian Ocean Diatom Zone 12}

Definition: The base of this zone has been defined at the first appearance of Nitzschia jouseae; the top at the extinction of Nitzschia cylindrica .

Discussion: Nitzschia jouseae first appears in equatorial east Pacific sediments at the top of the "c" event within the Gilbert reversed epoch (Burckle, 1972). Burckle (1972, p. 228) postulates an evolutionary transition of Nitzschia jouseae from its immediate ancestor Nitzschia cylindrica. This transition takes place just before, and within, the "c" event of the Gilbert reversed epoch. Associated species are: Actinocyclus divisus, A. ellipticus var. elongatus, Asterolampra affinis (first occurrence in the middle part of zone 12), A. marylandica, Asteromphalus arachne, A. heptactis, Coscinodiscus nodulifer, $C$. plicatus group 4, Ethmodiscus rex, Hemidiscus cuneiformis, H. simplicissimus, Nitzschia cylindrica, $N$. fossilis, $N$. interrupta, $N$. jouseae (first evolutionary appearance at the base of zone 12), $N$. marina, $N$. reinholdii, $N$. spec. 13 (extinction in the middle part of this zone), Roperia praetesselata, Thalassiosira convexa var. aspinosa, Thal. excentrica, Thal. gravida (?), Thal. nativa, Thal. spec. 6, Thalassionema nitzschioides, Thalassiothrix longissima, Th. frauenfeldii, Th. monospina (upper part of the zone), and Triceratium cinnamomeum.

Paleomagnetic stratigraphy: The base of this zone has been placed at the " $c_{1}$ " event of the Gilbert reversed epoch; the top at the "a" event (Cochiti) within the Gilbert reversed epoch.

Comparison with the zonation of other workers: Zone 12 correlates with the lower part of the Nitzschia jouseae Partial-range Zone of Burckle (1972) and the "Pliocene" of Muchina (1969)

Absolute age: $3,8-4,3$ m.y.

Geographical extent: Found in tropical Indian and Pacific Ocean sediments.

Type locality: DSDP Leg 24, Site 238, Core 12, Section 4, $70 \mathrm{~cm}$ to Core 15 , Section $1,40 \mathrm{~cm}$.

\section{Tropical Indian Ocean Diatom Zone 13}

Definition: The base of this zone has been defined at the extinction of Nitzschia porteri; the top at the first evolutionary appearance of Nitzschia jouseae.

Discussion: Coscinodiscus endoi appears last in this zone. Kanaya and Koizumi (1970) gave a range for tropical Pacific sediments from about N.9 to N.16. Here it ranges much higher. Actinocyclus moronensis was found last. Asteromphalus petersonii appeared first in the upper part of the zone as does Coscinodiscus plicatus group 4 and Nitzschia sp. 13.

Paleomagnetic stratigraphy: The base of this zone has not been defined; the top occurs at the " $c_{1}$ " event of the Gilbert reversed epoch.
Comparison with the zonation of other workers: Zone 13 correlates to the upper part of the Thalassiosira convexa Partial-range Zone of Burckle (1972).

Absolute age; 4, 3-(?). The base has not been estimated.

Geographical extent: Found in tropical Indian Ocean sediments.

Type locality: DSDP Leg 24, Site 238, Core 15, Section 2, $30 \mathrm{~cm}$ to Core 17 , Section $1,75 \mathrm{~cm}$.

\section{Tropical Indian Ocean Diatom Zone 14}

Definition: The base of this zone is defined by the extinction of Nitzschia miocenica; the top at the extinction of Nitzschia porteri.

Discussion: Nitzschia porteri is interpreted here after the description of Frenguelli (1949). It is not clear if Burckle (1972) used the same identification, as his $N$. porteri (Burckle, 1972, pl.2, fig. 16) is different in shape and striation; no morphologic description is presented. Asterolampra acutiloba becomes extinct at the top of this zone. Other elements are listed in Table 2.

Paleomagnetic stratigraphy: The base of this zone has been defined to occur within the "a" event of normal epoch 5 . The top has not been defined.

Comparison with the zonation of other workers: Zone 14 correlates to the middle part of the Thalassiosira convexa Partial-range Zone of Burckle (1972), Subzone B.

Absolute age: (?) - 6 m.y. on the Berggren (1972) time scale. The top has not been defined.

Geographical extent: Found in tropical Indian and Pacific Ocean sediments.

Type locality: DSDP Leg 24, Site 238, Core 17, Section 2, $75 \mathrm{~cm}$ to Core 17 , Section $6,75 \mathrm{~cm}$.

\section{Tropical Indian Ocean Diatom Zone 15}

Definition: The base of this zone has been defined at the first appearance of Thalassiosira miocenica; the top at the extinction of Nitzschia miocenica.

Discussion: Thalassiosira miocenica may be the same species as Burckle.s (1972) Thalassiosira usatchevii. The author does not present pictures of Thal. usatchevii but notes (1972, э. 228): “Thalassiosira convexa (after the interpretation used in this paper Thal. convexa var. aspinosa) appears just after the first appearance of Thal. usatchevii. Throughout the range of this species there is a general, though small, increase in size." "Thalassiosira usatchevii appears first and is characterized chiefly by an increase in diameter over its ancestor and an increase in size of the areolae." I have investigated original LDGO material (RC-12-65) from the Thalassiosira convexa Partial-range Zone and could not find a species fitting into the morphology of Thal. usatchevii (for ref. see Sheshukova-Poretzkaya, $1967, \quad$ p. $150,38-50 \mu$ in diameter, with bent out margin $[5 \mu$ wide $], 3.5$ areolae in $10 \mu$ ). Therefore, I gave this species a new name. The Indian Ocean individuals are nearly congruent to those found in the Pacific materials. Thalassiosira miocenica belongs in the evolutionary line of Thalassiosira praeconvexa (not found at either one of the sites, but has been treated in Schrader, 1974) over Thalassiosira 
convexa var. aspinosa to Thalassiosira convexa. Asteromphalus arachne appears first at the base of this zone as does Asteromphalus hookeri and Thalassiosira convexa var. aspinosa. Other floral elements are listed on Table 2.

Paleomagnetic stratigraphy: The base of this zone occurs within magnetic reversed epoch 6 , the top within the "a" event of magnetic normal epoch 5 .

Comparison with the zonation of other workers: Zone 15 is correlative to the lowest part of the Thalassiosira convexa Partial-range Zone of Burckle (1972).

Absolute age: 6-6.5 m.y. on the Berggren $(1969,1972)$ time scale.

Geographical extent: Found in tropical Indian and Pacific Ocean sediments.

Type locality: DSDP Leg 24, Site 238, Core 18, Section 2, $75 \mathrm{~cm}$ to Core 19 , Section $5,75 \mathrm{~cm}$.

\section{Tropical Indian Ocean Diatom Zone 16}

Definition: The base of this zone has been defined at the extinction of Cussia paleacea; the top at the first appearance of Thalassiosira miocenica.

Discussion: Nitzschia miocenica does range well over the extinction level of Cussia paleacea in Indian Ocean sediments. Thalassiosira sp. 7 appears first near the top of this zone (this species has been described as Thalassiosira lineata by Muchina 1969, but is different). Other floral elements are listed in Table 2. This zone should be investigated in more detail in the near future, as the samples showed a moderately well preserved diatom assemblage. Within this zone and the two following, 17-18 long specimens of Cussia sp. were observed (for reference see Burckle, 1972, p. 225).

Paleomagnetic stratigraphy: The base of this zone falls within the "a" event in magnetic normal epoch 7, the top within magnetic reversed epoch 6 .

Comparison with the zonation of other workers: Zone 16 is correlative to the upper part of the Nitzschia miocenica Partial-range Zone of Burckle (1972).

Absolute age: 6.5-6.9 m.y. on the Berggren $(1969,1972)$ and Abdel-Monem et al. (1971) time scale.

Geographical extent: Found in tropical Indian Ocean sediments.

Type locality: DSDP Leg 24, Site 238, Core 19, CC to 20, CC.

\section{Tropical Indian Ocean Diatom Zone 17}

Definition: The base of this zone has been defined at the first appearance of Nitzschia miocenica; the top at the extinction of Cussia paleacea.

Discussion: Burckle (1972) assumed an evolutionary transition between Nitzschia porteri and Nitzschia miocenica. I do not agree and have found some other forms which belong to the evolutionary line Nitzschia marina, Nitzschia reinholdii, and Nitzschia indica. The event has not yet been well defined and detailed results on the evolution of this whole Nitzschia group will be published at a later date. Floral elements are: Actinocyclus ehrenbergii var. tenella, A. ellipticus var. elongatus (first occurrence in this zone), A. ellipticus var. javanica (becoming extinct in the middle part of this zone), A. moronensis (synonym: A. ellipticus var. moronesis) becomes extinct at the top of this zone and may be useful in defining the upper limit of the zone, Asterolampra acutiloba (appears first), A. grevillei, A. marylandica, Coscinodiscus endoi, $C$. lineatus, $C$. nodultjer, $C$. vetustissimus, Ethmodiscus rex, Cussia paleacea, Cus. praepalacea, Hemidiscus cuneiformis, $H$. simplicissimus, Nitzschia cylindrica, $N$. interrupta (first appearance in this zone), $N$. marina (first appearance in the middle of the zone), $N$. miocenica, $N$. porteri, $N$. reinholdii, Rouxia moholensis, Thalassiosira excentrica, Thalassionema nitzschioides, Th. lineata, Thalassiothrix longissima, T. monospina, and Triceratium cinnamomeum.

Paleomagnetic stratigraphy: This zone ranges from the middle part of magnetic normal epoch 7 to the " $a$ " event within the magnetic normal epoch 7 .

Comparison with the zonation of other workers: Zone 17 is correlative to the lower part of the Nitzschia miocenica Partial-range Zone of Burckle (1972).

Absolute age: 6.9-7.2 m.y. on the Berggren $(1969,1972)$ and Abdel-Monem et al. (1971) time scale.

Geographical extent: Found in tropical Indian and Pacific Ocean sediments.

Type locality: DSDP Leg 24, Site 238, Core 21, Section 2, $100 \mathrm{~cm}$ to Core 23 , Section $2,75 \mathrm{~cm}$.

\section{Tropical Indian Ocean Diatom Zone 18}

Definition: The base of this zone is placed at the first appearance of Nitzschia cylindrica, the top at the first appearance of Nitzschia miocenica.

Discussion: Although Nitzschia cylindrica is rare in zones 18 and 17 , it is possible to define its first appearance; it is not yet clear if Nitzschia cylindrica evolved from an ancestor. Other floral elements are listed in Table 2.

Paleomagnetic stratigraphy: This zone ranges from the base of the magnetic epoch 7 to the middle part of magnetic normal epoch 7.

Comparıson with the zonation of other workers: Zone 18 is correlative to the upper part of the Nitzschia porteri Partial-range Zone of Burckle (1972).

Absolute age: 7.2-7.6 m.y. on the Berggren $(1969,1972)$ and Abdel-Monem et al. (1971) time scale.

Geographical extent: Found in tropical Indian and Pacific Ocean sediments.

Type locality: DSDP Leg 24, Site 238, Core 23, Section 5, $75 \mathrm{~cm}$ to $23, \mathrm{CC}$.

\section{Tropical Indian Ocean Diatom Zone 19}

Definition: The base of this zone is placed at the extinction of Coscinodiscus yabei; the top at the first appearance of Nitzschia cylindrica.

Discussion: Other important floral elements are: Coscinodiscus endoi, Nitzschia porteri, Cussia paleacea, Cus. praepaleacea, Actinocyclus moronensis, Thalassiosira burckliana (for more detail see Table 2).

Paleomagnetic stratigraphy: This zone ranges from the base of magnetic epoch 7 to the middle part of magnetic epoch 8 .

Comparison with the zonation of other workers: Zone 19 is correlative to the lower part of the Nitzschia porteri Partial-range Zone of Burckle (1972). 
Absolute age: 7.6-8.2 m.y. on the Berggren $(1969,1972)$ and Abdel-Monem et al. (1971) time scale.

Geographical extent: Found in tropical Indian Ocean sediments.

Type locality: DSDP Leg 24 , Site 238 , Core 24 , Section 2 , $70 \mathrm{~cm}$ to $26, \mathrm{CC}$.

\section{Tropical Indian Ocean Diatom Zone 20}

Definition: The base of this zone is placed at the first occurrence of Nitzschia porteri; the top at the extinction of Coscinodiscus yabei.

Discussion: Floral list is in Table 2.

Paleomagnetic stratigraphy: This zone ranges from the lower part of magnetic epoch 8 to the middle part of magnetic epoch 8 .

Comparison with the zonation of other workers: Zone 20 is correlative to the uppermost part of the Coscinodiscus yabei Partial-range Zone of Burckle (1972).

Absolute age: 8.2-8.6 m.y. on the Berggren $(1969,1972)$ and Abdel-Monem et al. (1971) time scale.

Geographical extent: Found in tropical Indian Ocean sediments.

Type locality: DSDP Leg 24, Site 238, Core 27, Section 2, $125 \mathrm{~cm}$ to Core 28 , Section $5,75 \mathrm{~cm}$.

\section{Tropical Indian Ocean Diatom Zone 21}

Definition: The base of this zone is placed at the last appearance of Denticula hustedtii from tropical sediments; the top at the first occurrence of Nitzschia porteri.

Discussion: Floral list is in Table 2.

Paleomagnetic stratigraphy: This zone ranges from the lower part of magnetic epoch 8 to the middle part of magnetic epoch 9 .

Comparison with the zonation of other workers: Zone 21 is correlative to the Coscinodiscus yabei Partial-range Zone of Burckle (1972).

Absolute age: 8.6-10 m.y. (?) on the Berggren $(1969,1972)$ and Abdel-Monem et al. (1971) time scale.

Geographical extent: Found in tropical Indian and Pacific Ocean sediments.

Type locality: DSDP Leg 24 , Site 238 , Core 28 , CC to 29 , CC.

\section{EPOCH AND AGE BOUNDARIES}

Burckle (1972) and Opdyke (1972) placed epochal and stage boundaries with respect to the paleomagnetic stratigraphy as follows.

1) The middle/late Miocene boundary (interpreted as the Langhian/Tortonian boundary) occurs in geomagnetic epoch 11. This epoch has been correlated to the Discoaster hamatus Zone, which is correlative to the Globorotalia menardii foraminiferal zone.

2) The Miocene/Pliocene boundary falls at the end of geomagnetic epoch 5 (interpreted as the beginning of the Tabianian [Mayer-Eymar, 1868]. This epoch has been correlated to the N.17-N.18 foraminiferal standard zone of Blow (1969) using Saito's (1969) foraminiferal criteria.

3) The Pliocene/Pleistocene boundary occurs during the Olduvai event of the Matuyama reversed geomagnetic epoch
(Berggren et al., 1967; Saito in Hays et al., 1969; Burckle 1969 a.o.).

These boundaries have been proposed also by Berggren (1972) and have been used in this paper (Figures 5 and 6).
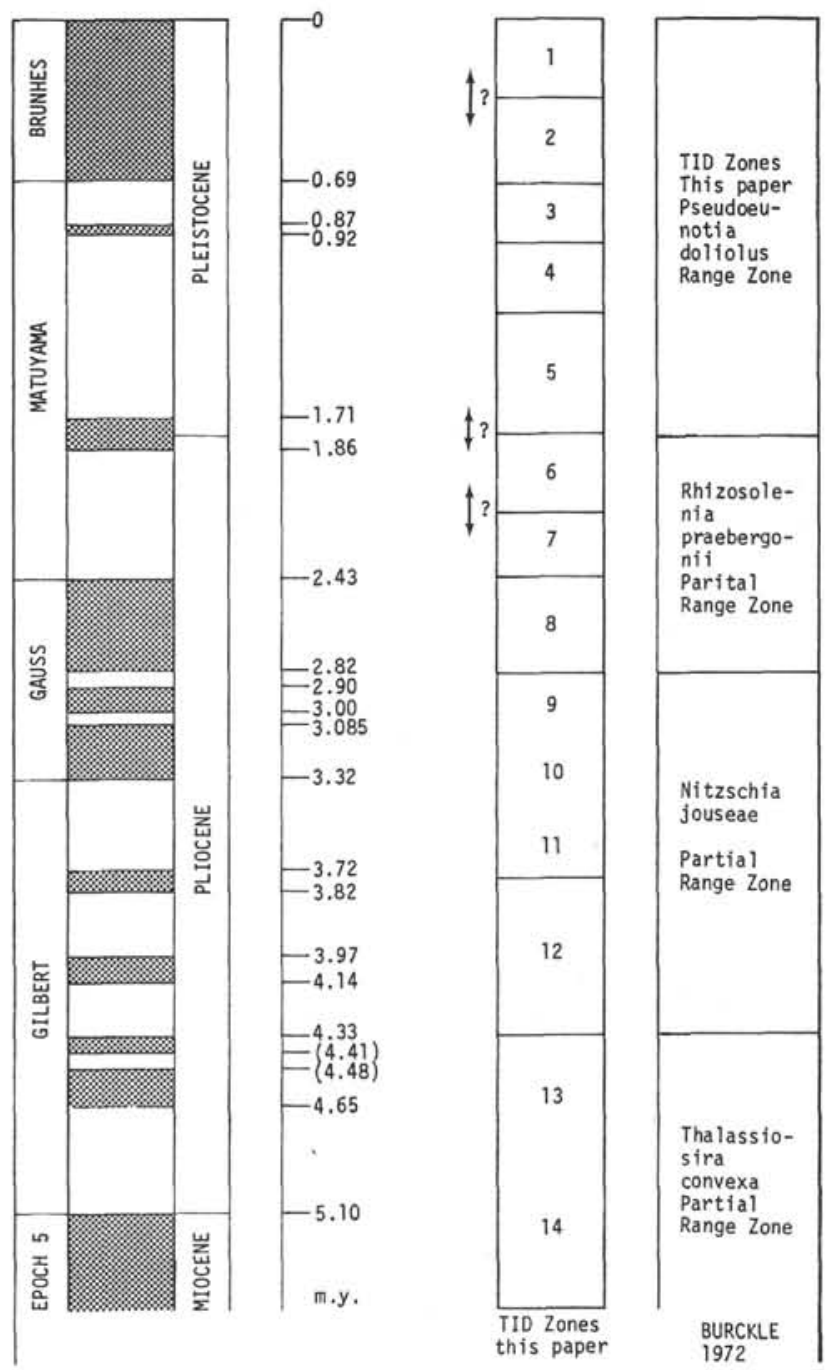

Figure 5. Correlation of tropical Indian Ocean diatom zones (TID zones) with the paleomagnetic stratigraphy, with the radiometric time scale, ad with the equatorial Pacific diatom zonation of Burckle (1972) for the Pleistocene-Pliocene interval.

\section{GEOCHRONOLOGICAL TIME SCALE}

The biostratigraphy of planktonic diatoms from the equatorial east Pacific (Burckle 1969, 1972) has been correlated to the paleomagnetic stratigraphy. Various authors have since then published correlations of the paleomagnetic stratigraphy to a radiometric time scale. Berggren (1972), Opdyke (1972), Abdel-Monem et al. (1971), Cox (1969) among others have established charts demonstrating the proposed comparisons of the radiometric time scale to the paleomagnetic time scale. In this paper I have used the modified time scales of Opdyke (1972), Abdel-Monem et al. (1971), and Berggren (1972) (Figure 7). 

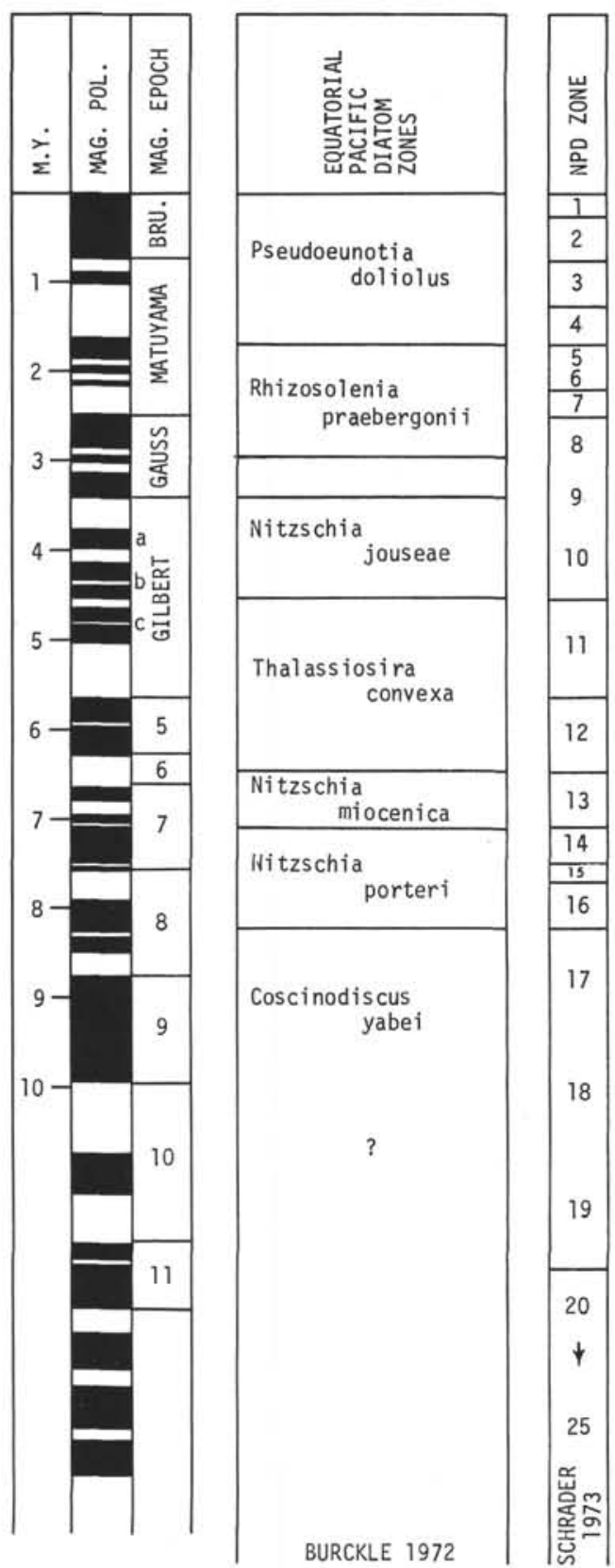
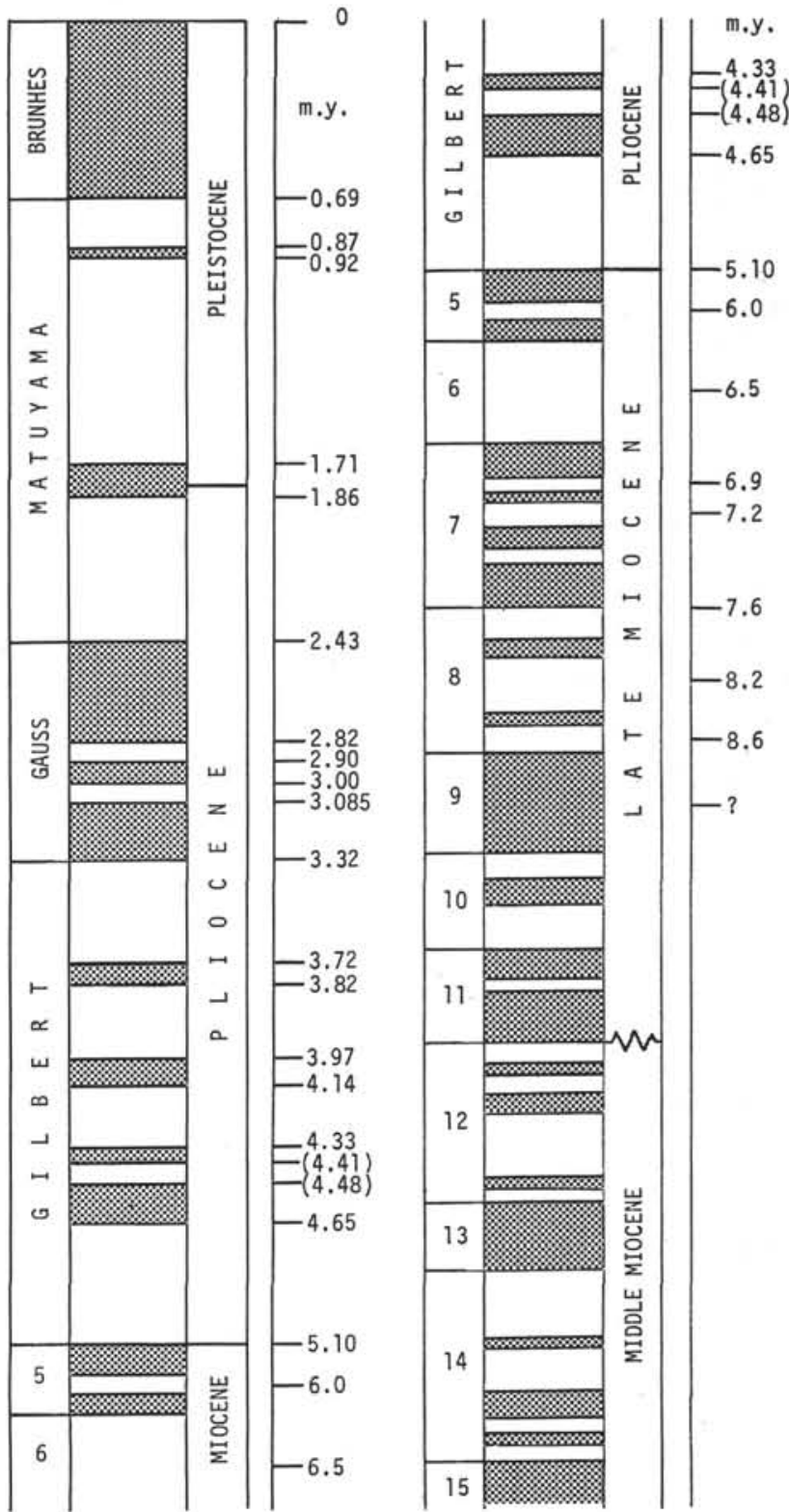

Figure 7. Paleomagnetic stratigraphy, epoch boundaries, and radiometric time scale used in this paper.

Figure 6. Correlation of tropical Indian Ocean diatom zones (TID zones) with the paleomagnetic stratigraphy, with the equatorial Pacific diatom zonation of Burckle (1972) with the north Pacific diatom zonation (NPD zones) of Schrader (1973a) for the Pleistocene-late/ middle Miocene interval.

The Pleistocene-Pliocene boundary, occurring in the Olduvai event, falls within 1.71 to 1.86 m.y.; the Pliocene-Miocene boundary, occurring at the top of geomagnetic epoch 5, falls at 5.10 m.y. (Figure 7). Other data within the late Miocene interval are interpolated from Abdel-Monem et al. (1971) and Berggren (1972). The late-middle Miocene boundary occurs tentatively between geomagnetic epochs 11 and 12 (Burckle, 1972; Opdyke, 1972), defining this boundary on the basis of correlating epoch 11 in equatorial Pacific sediments to the Discoaster

hamatus Zone which is correlative to the Globorotalia meyeri Zone, the highest zone in the middle Miocene. This boundary has an interpolated radiometric age of 10.5 m.y. according to the Berggren $(1969,1972)$ time scale.

\section{CORRELATION TO OTHER DIATOM SECTIONS}

Planktonic marine diatoms have been used to establish the ages and correlations of some other deep-sea drilling sections. They are: the Experimental Mohole Drilling (Schrader, 1974), DSDP Leg 18, Site 173 (Schrader, 1973a), the east equatorial Pacific (Burckle, 1969, 1972), the equatorial Pacific (Buckry and Foster, 1973) and the Pacific and Indian Oceans (Muchina, 1969). Correlations which are tentative and cannot be proven because of the lack of original material and poor descriptions are 
connected with a dashed line; others which have been proven by the author and showed good agreement are connected with a solid line (Figure 8).

The correlation between DSDP Leg 22, Sites 213 and 215 , and DSDP Leg 24 , Site 238 is based exclusively on the floral content and the placement of the tropical Indian Ocean diatom zones. Differences in the stratigraphic interpretation of DSDP Leg 22, Sites 213 and 215 by other microfossils may be resolved by comparing the Leg 22 results.

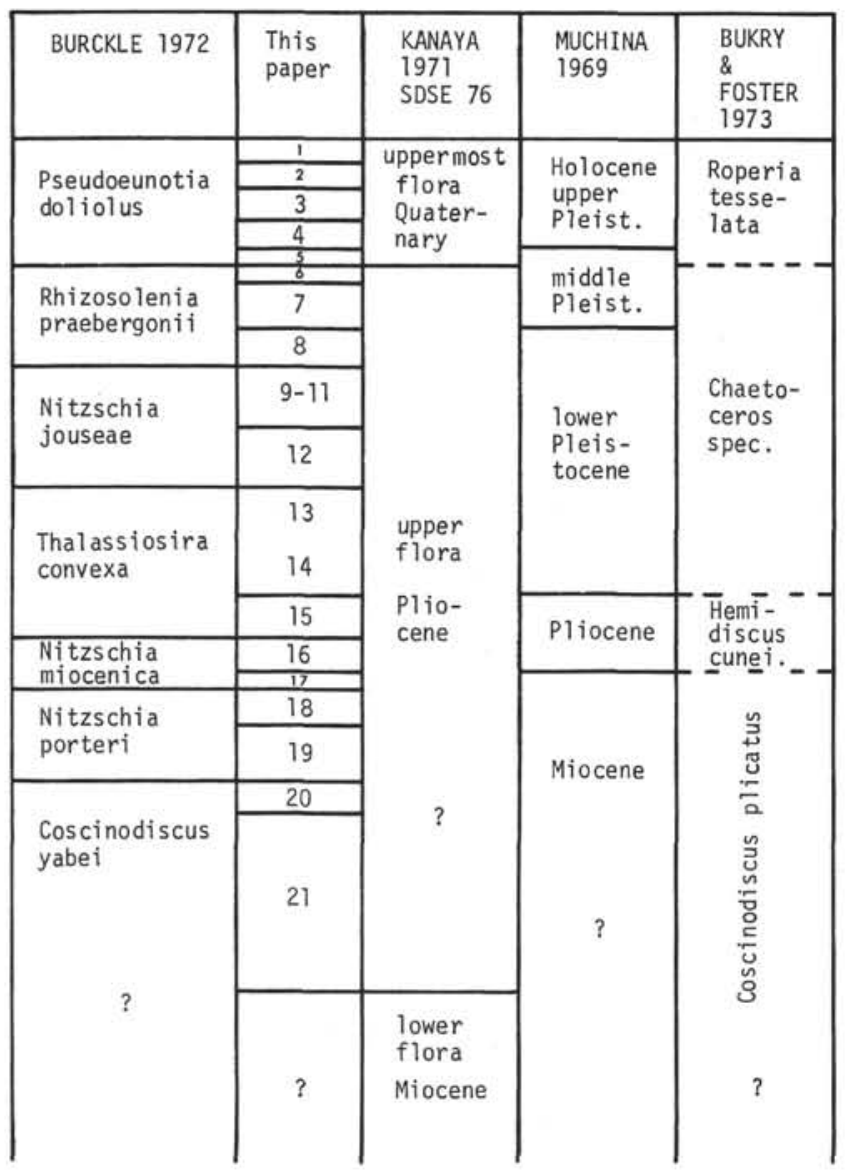

Figure 8. Correlation of various diatom zonations applied to tropical-subtropical diatom sequencies from the Pacific and Indian oceans.

\section{DIATOMS AT EACH SITE}

\section{Site 236}

Diatoms are rare to absent in most samples collected from Site 236. There are a few samples from Cores 1 and 2 which contain a well to moderately preserved diversified diatom assemblage characteristics of a warm-water thanatocoenoses. No Ethmodiscus ooze was detected within this interval although a few reworked older fossils (Nitzschia jouseae and Rhizosolenia praebergonii) were found. A detailed list of the species content is given in Table 1 .

The base of TID Zone 3 was recognized at approximately 15 meters below the sea floor. Other younger zones were not present. The interval from approximately 20 to 220 meters below the sea floor was barren of diatoms except for the following samples which contained reworked and/or displaced shallow-water robust species: 3, CC (Trinacria regina); 9, CC (Melosira sulcata); $11-1,131 \mathrm{~cm}$ (Coscinodiscus cf. radiatus); 12-5, $108 \mathrm{~cm}$ (Arachnoidiscus spec.); 13-2, $130 \mathrm{~cm}$ (Ethmodiscus rex); $17-2,148 \mathrm{~cm}$ (Melosira sulcata); 22-4, $116 \mathrm{~cm}$ (fragments of Coscinodiscus); 23-3, $80 \mathrm{~cm}$ (Grammatophora sp., Pyxilla sp.); and 23, CC (Grammatophora sp.).

The interval from about 220 to 255 meters below the sea floor contained a few robust species such as Pyxilla sp., Liostephania stages of Asterolampra, Stephanopyxis sp., Triceratium sp., and Trinacria sp., proving these samples to be Oligocene to Eocene in age.

The interval from 270 to 320 meters below the sea floor was barren of diatoms.

The interval from 220 to 255 meters below the sea floor contained only rare diatom assemblages which were in part strongly etched and showed corrosion. The diversity of species was very low and therefore no detailed investigation was done.

The abundance of sponge spicules, increased abruptly within the 20-220 meter interval within the following horizons: $4-3,50 \mathrm{~cm} ; 8-3,135 \mathrm{~cm} ; 8-5,59 \mathrm{~cm} ; 9-2,102 \mathrm{~cm}$ to $13, \mathrm{CC} ; 20-2,100 \mathrm{~cm}$; and $22-2,74 \mathrm{~cm}$ to $28, \mathrm{CC}$. This may indicate: (1) the strong dissolution of biogenic opal, and (2) the influx of shallow-water material if other opal skeletons are rare or absent from the assemblage.

\section{Site 238}

Diatoms are common to abundant and moderately to well preserved from 0-215 meters below the sea floor; they are moderately to poorly preserved from 215-293 meters. The interval from 293-568.5 meters is barren of diatoms except for a few reworked and/or displaced individuals and poorly preserved assemblages. The typical tropical diatom assemblages yielded various species allowing good floral zonation and will serve as a link between tropical Pacific zonations and Mediterranean diatom zonations being worked out at the moment. The sequence from $0-215$ meters represents a continuous record of diatom production from today to the late Miocene. No specific climatic investigations were made, but from the species assemblage, it can be concluded that no real temperature change from tropical to cold occurred. Older reworked microfossil occurrence may be found in Table 2. The abundance of displaced shallow-water diatom species is low throughout this section. A few horizons were found enriched in Ethmodiscus. Detailed reference to the systematic composition of diatom floras is given in Table 2 .

At this site, the base of the TID zones was observed to occur as follows:

TID Zone 1 at 3.5 meters $(1-3,75 \mathrm{~cm})$

TID Zone 2 at 13.5 meters $(2-3,75 \mathrm{~cm})$

TID Zone 3 at 27 meters $(3-6,75 \mathrm{~cm})$

TID Zone 4 at 38 meters $(4, C C)$

TID Zone 5 at 49 meters $(6-4,75 \mathrm{~cm})$

TID Zone 6 at 57 meters $(7-3,60 \mathrm{~cm})$

TID Zone 7 at 60 meters $(7-5,40 \mathrm{~cm})$

TID Zone 8 at 64.5 meters $(8-2,32 \mathrm{~cm})$

TID Zone 9 at 72.5 meters $(9-1,30 \mathrm{~cm})$

TID Zone 10 at 101 meters $(11-6,70 \mathrm{~cm})$ 
TABLE 1

Distribution of Diatoms and Other Siliceous Nannofossils, Site 236

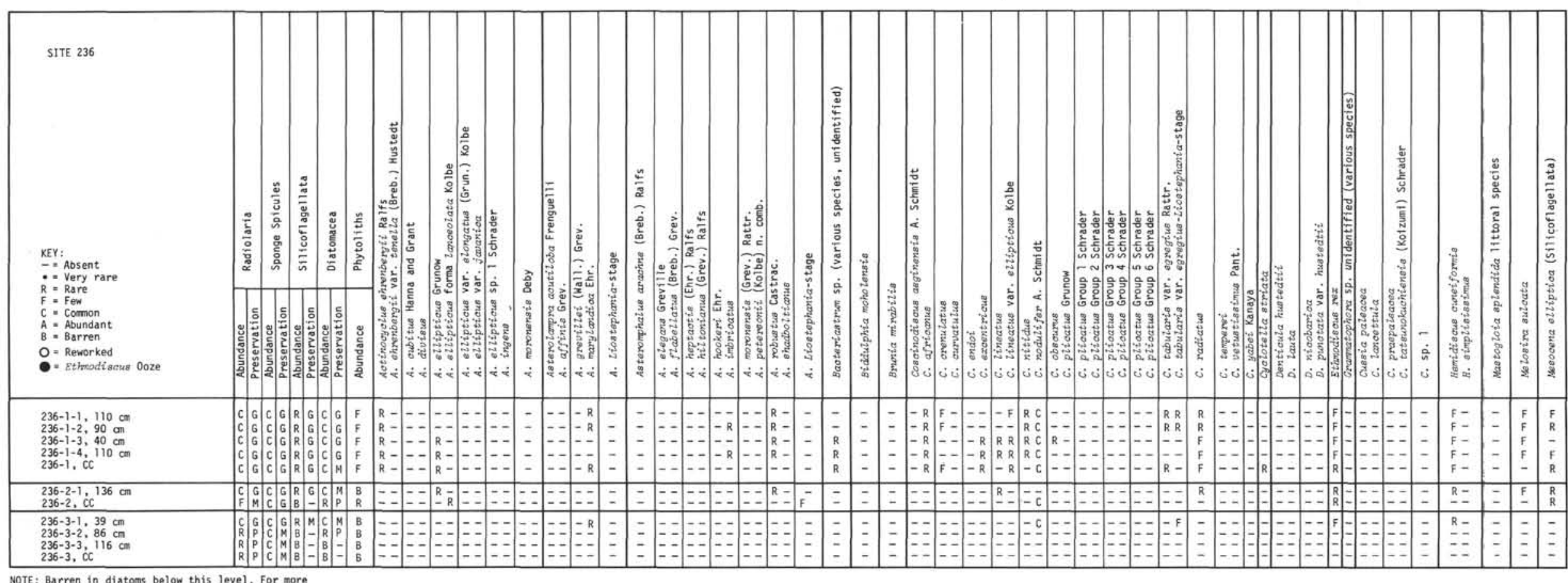

NOTE: Barren in diatoms below this level. For more
detail for the lower part of the section see
the text. 
TABLE 1 - Continued

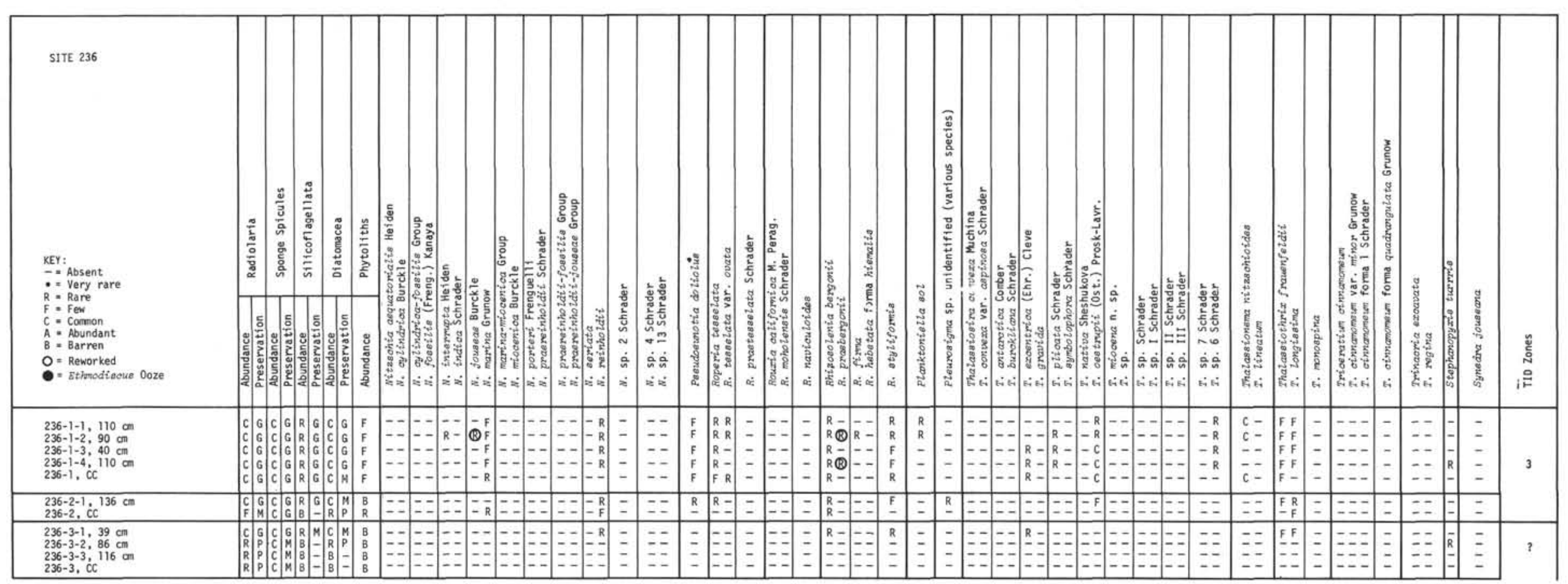

DTE: Barren in diatons below this level. For more
detail for the lower part of the section see
the toxt. 
TID Zone 11 at 104.5 meters $(12-3,70 \mathrm{~cm})$

TID Zone 12 at 130 meters $(15-1,75 \mathrm{~cm})$

TID Zone 13 at 151 meters $(17-2,75 \mathrm{~cm})$

TID Zone 14 at 156.5 meters $(17-6,75 \mathrm{~cm})$

TID Zone 15 at 174 meters $(19-5,75 \mathrm{~cm})$

TID Zone 16 at 186.5 meters $(20$, CC)

TID Zone 17 at 207.5 meters $(23-2,75 \mathrm{~cm})$

TID Zone 18 at 215 meters $(23, \mathrm{CC})$

TID Zone 19 at 243.5 meters $(26, C C)$

TID Zone 20 at 259.5 meters $(28-5,75 \mathrm{~cm})$

TID Zone 21 at 272 meters $(29$, CC)

No breaks in the diatom stratigraphic record were found from 0-272 meters. Based on placement of the bottom of Tropical Indian Ocean Diatom Zone 5 (Pleistocene-Pliocene boundary) at 49 meters, the base of Tropical Indian Ocean Diatom Zone 13 (tentative Miocene-Pliocene boundary) at 151 meters, and other horizons with absolute ages estimated on the basis of Berggren's (1969, 1972), and Opdyke's (1972) correlations with the radiometricpaleomagnetic time scale, indications are that the interval from 0-293 meters below the sea floor (Pleistocene to late Miocene) has a sedimentation rate of $30 \mathrm{~m} / \mathrm{m}$.y. (Figure 9). The sequence from 293-568.5 meters contains only a few reworked and/or displaced individuals (Trinacria regina [41-2, $72 \mathrm{~cm}])$. Ethmodiscus ooze was found at 1-6, $75 \mathrm{~cm}$ to $2-2,75 \mathrm{~cm}, 5-4,90 \mathrm{~cm}$ to $6-1,11 \mathrm{~cm}$ and at $7-4,70 \mathrm{~cm}$.

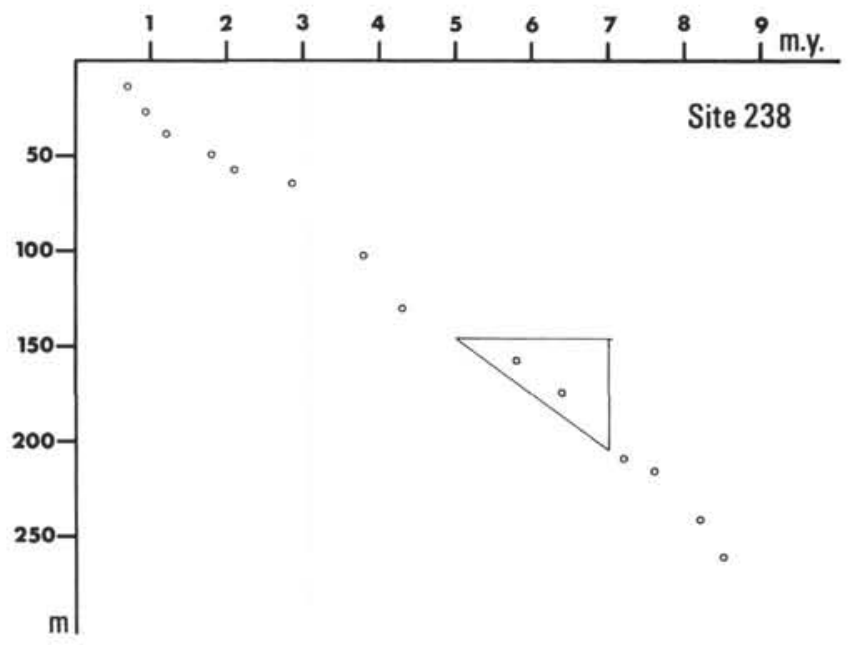

Figure 9. Sediment accumulation rate at Site 238.

\section{Site 213 (DSDP Leg 22)}

The diatom-radiolarian ooze at this site for the upper sequence from $1-1,50-51 \mathrm{~cm}$ to $8-5,50-51 \mathrm{~cm}$ suggests the onset of high biogenetic productivity with only the siliceous component being preserved below the calcium carbonate compensation depth (CCD) from late Miocene until today. No detailed climatic investigations were made on these excellently preserved diatom assemblages, but from the species composition it can be suggested that no real cool period is represented. Older reworked microfossils occur sporadically. A few horizons were found to represent Ethmodiscus ooze $(1-1,50-51 \mathrm{~cm} ; 1-3,50-51 \mathrm{~cm} ; 2-1$, $50-51 \mathrm{~cm} ; 4-1,50-51 \mathrm{~cm} ; 4-4,50-51 \mathrm{~cm})$. Detailed reference to the systematic composition of diatom floras is given in Table 3.
At this site, the base of the TID zones was observed to occur as follows:

TID Zones 1 and 2 at 2 meters $(1-2,100-101 \mathrm{~cm})$

TID Zone 3 at 3.5 meters $(1-3,50-51 \mathrm{~cm})$

TID Zones 4 and 5 at 9.5 meters $(2-1,50-51 \mathrm{~cm})$

TID Zone 6 at 22 meters $(3-3,50-51 \mathrm{~cm})$

TID Zone 7 at 28.5 meters $(4-1,50-51 \mathrm{~cm})$

TID Zones 8.10 at 39.5 meters $(5-2,50-51 \mathrm{~cm})$

TID Zone 11 at 50.5 meters $(6-3,50-51 \mathrm{~cm})$

TID Zone 12 at 58.5 meters $(7-2,50-51 \mathrm{~cm})$

TID Zones 13 and 14 at 68 meters $(8-2,50-51 \mathrm{~cm})$

TID Zone 15 the base has not been defined.

No breaks in the diatom stratigraphic record were observed. Recognition of the tropical Indian Ocean diatom zones was in some cases tentative. This a result of widely placed samples, and/or coring disturbance (mixing of soupy material). Based on the placement of the bottom of Tropical Indian Ocean Diatom Zone 5 (Pleistocene-Pliocene boundary) between Samples 2-1, 50-51 cm and 2, CC, the base of Tropical Indian Ocean Diatom Zone 13 (tentative Miocene-Pliocene boundary) between Samples 7, CC and $8-1,50-51 \mathrm{~cm}$, and other horizons with absolute ages estimated on the basis of Berggren's (1969, 1972), Opdyke's (1972) correlations with the radiometricpaleomagnetic time scale, indications are that the interval from $0-80$ meters below the sea floor (Pleistocene to late Miocene) has a sedimentation rate of $26 \mathrm{~m} / \mathrm{m} . \mathrm{y}$. (Figure 10).

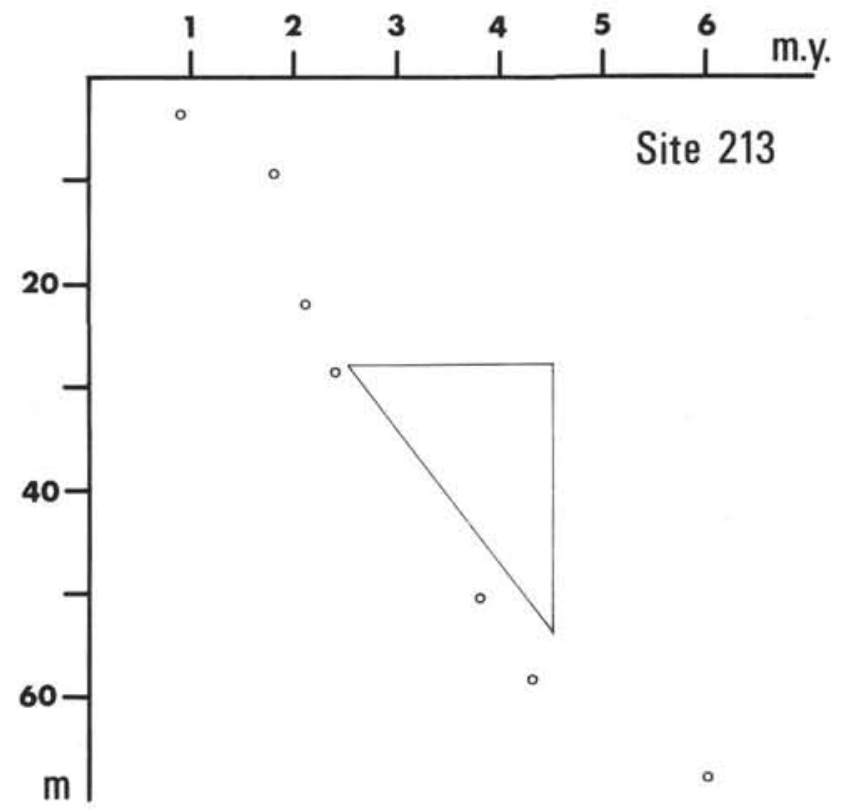

Figure 10. Sediment accumulation rate at Site 213.

\section{Site 215 (DSDP Leg 23)}

The diatom-radiolarian ooze sequence from 1-1, 50-51 cm to 7, CC resembles Site 213, which was drilled on the opposite site of the Ninetyeast Ridge in 5310 meters of water. The consistent occurrence of abundant siliceous tests suggests a high biogenetic productivity, with only the opaline silica being preserved below the CCD from late Miocene until today. No detailed climatic investigations were made on these excellently preserved diatom 
TABLE 2

Distribution of Diatoms and Other Siliceous Nannofossils, Site 238

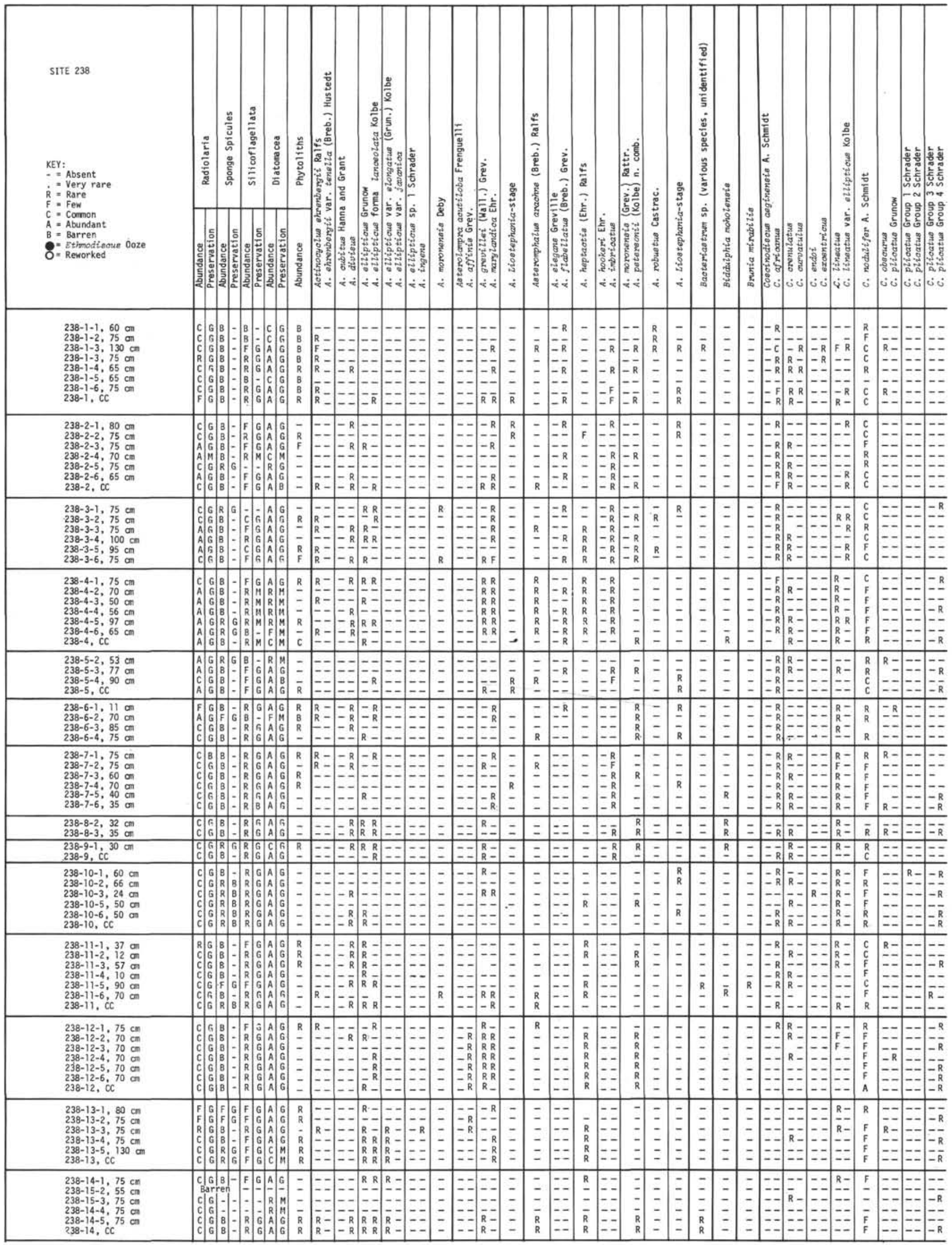


TABLE 2 - Continued

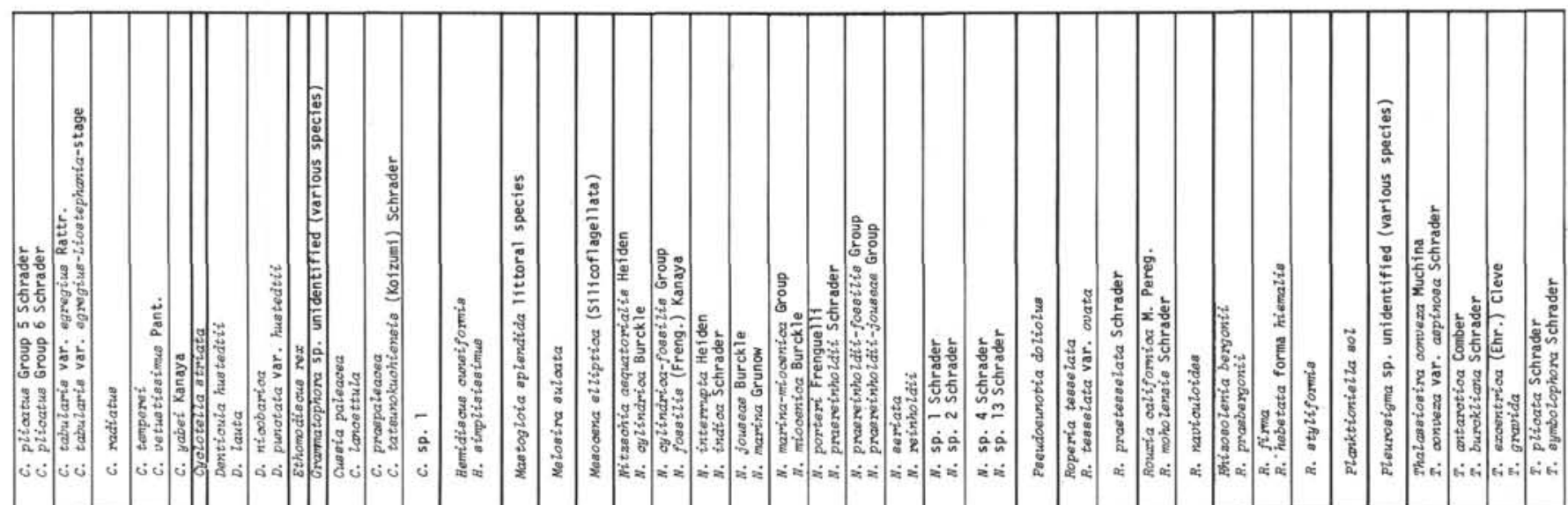

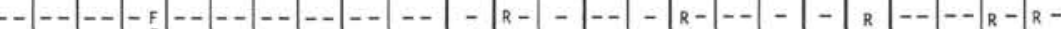

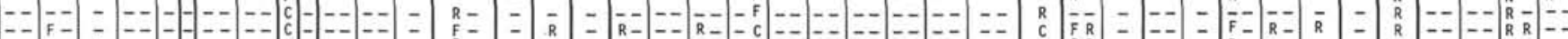

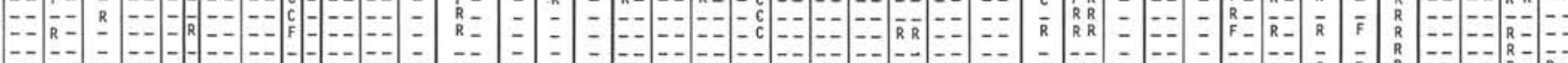

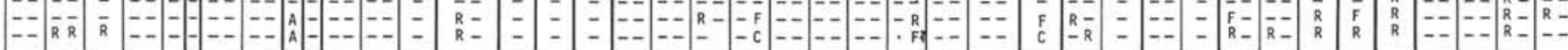

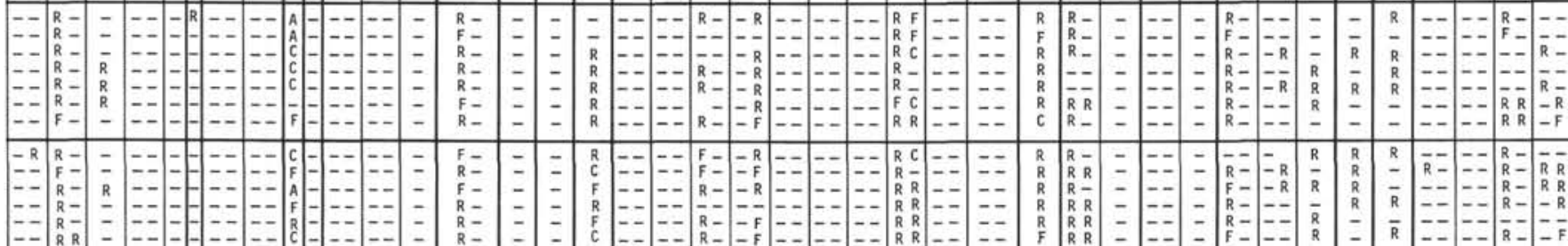

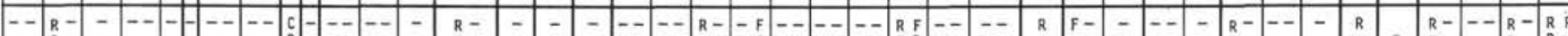

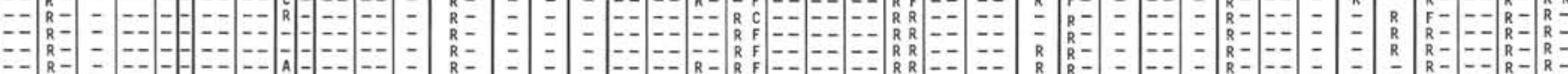

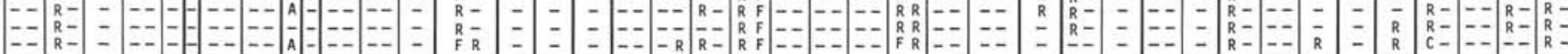

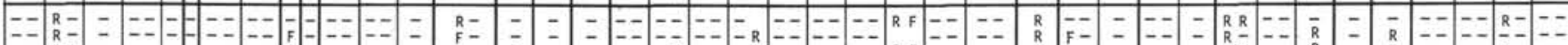

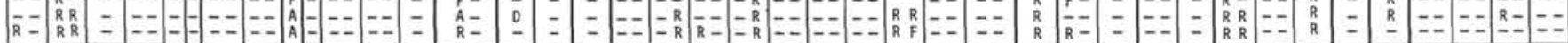

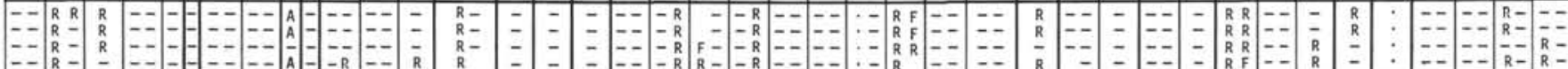

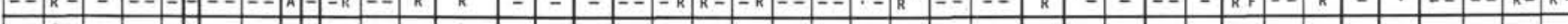

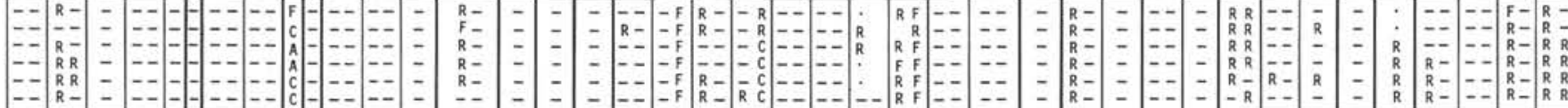

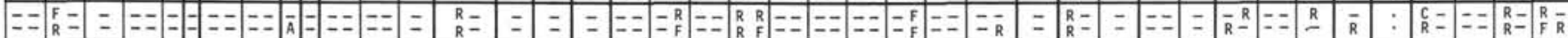

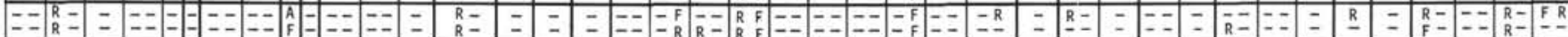

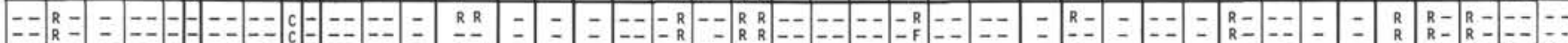

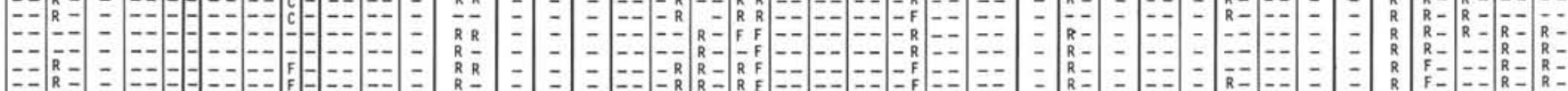

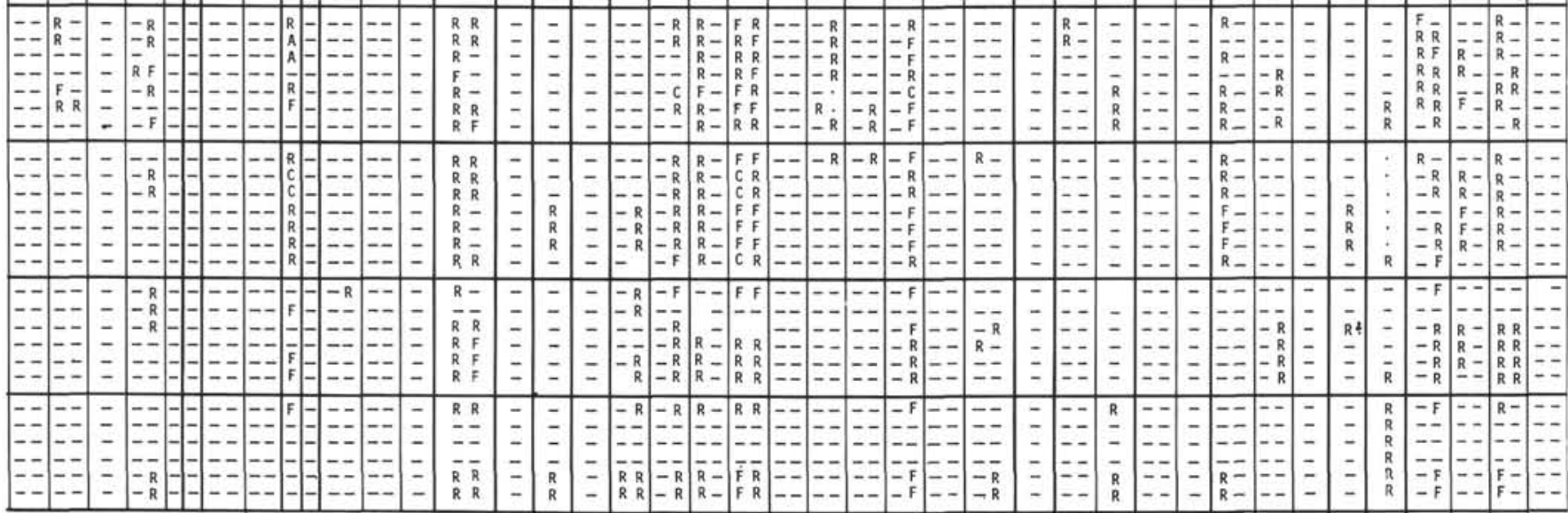


TABLE 2 - Continued

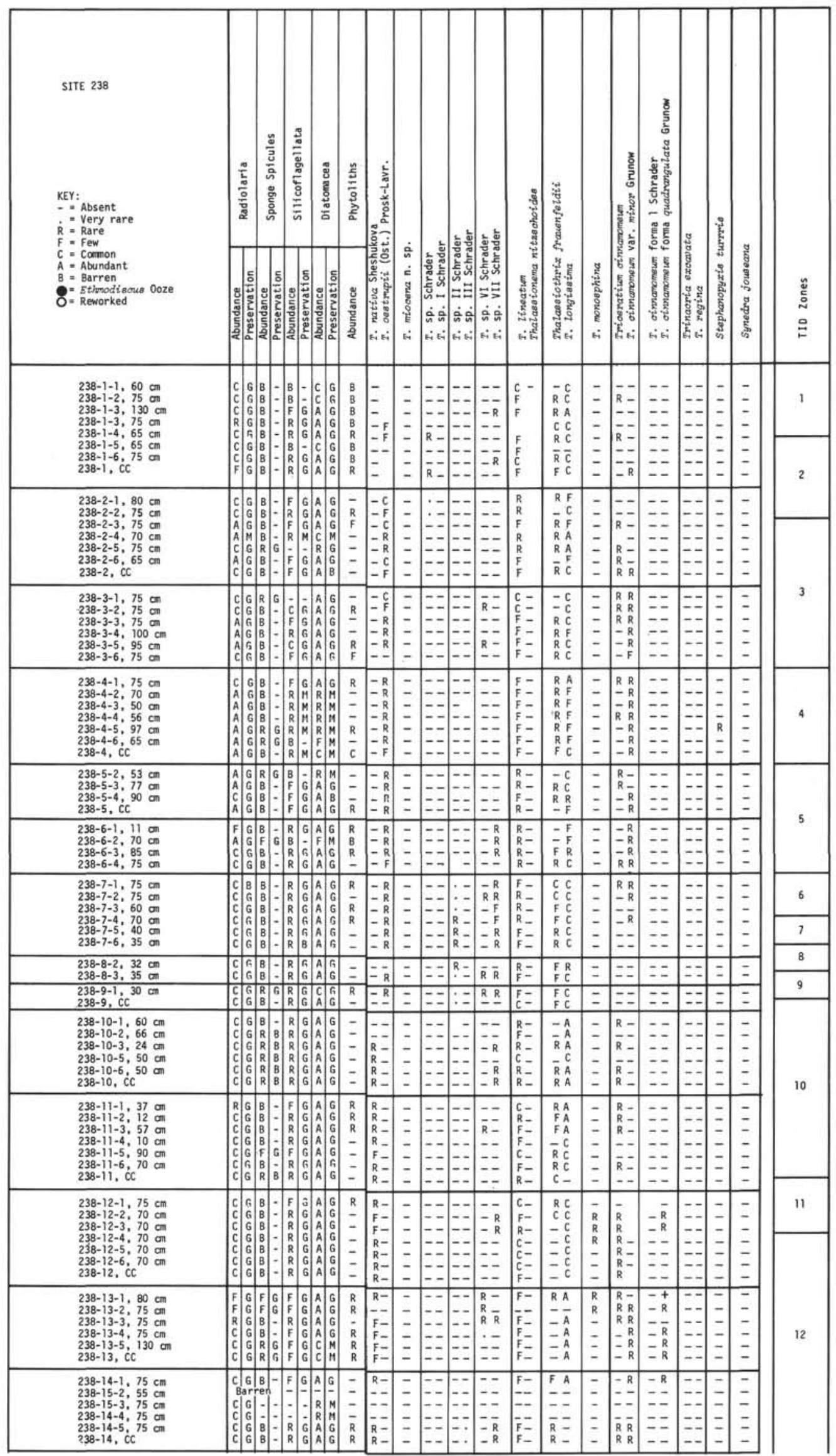


TABLE 2 - Continued

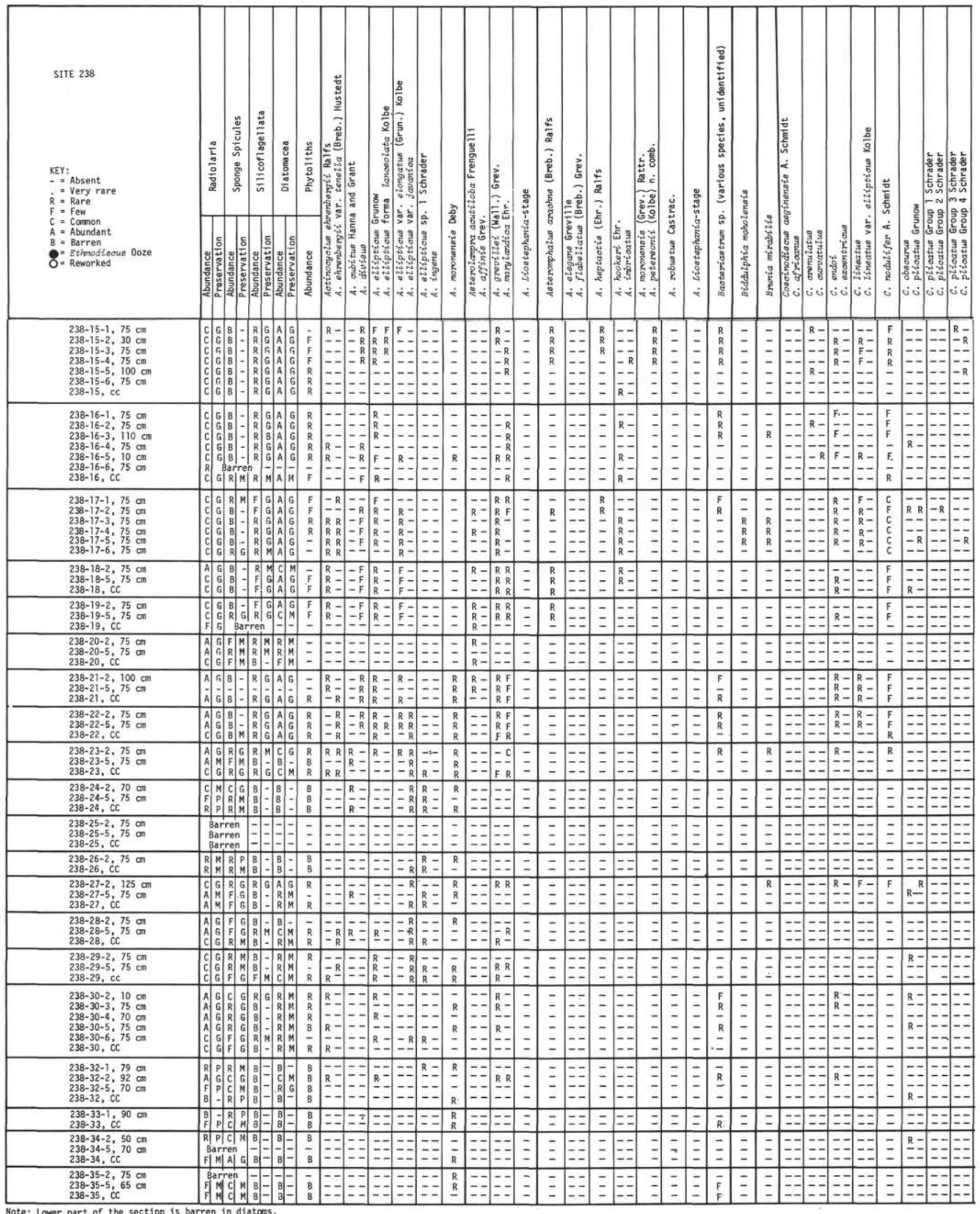


TABLE 2 - Continued

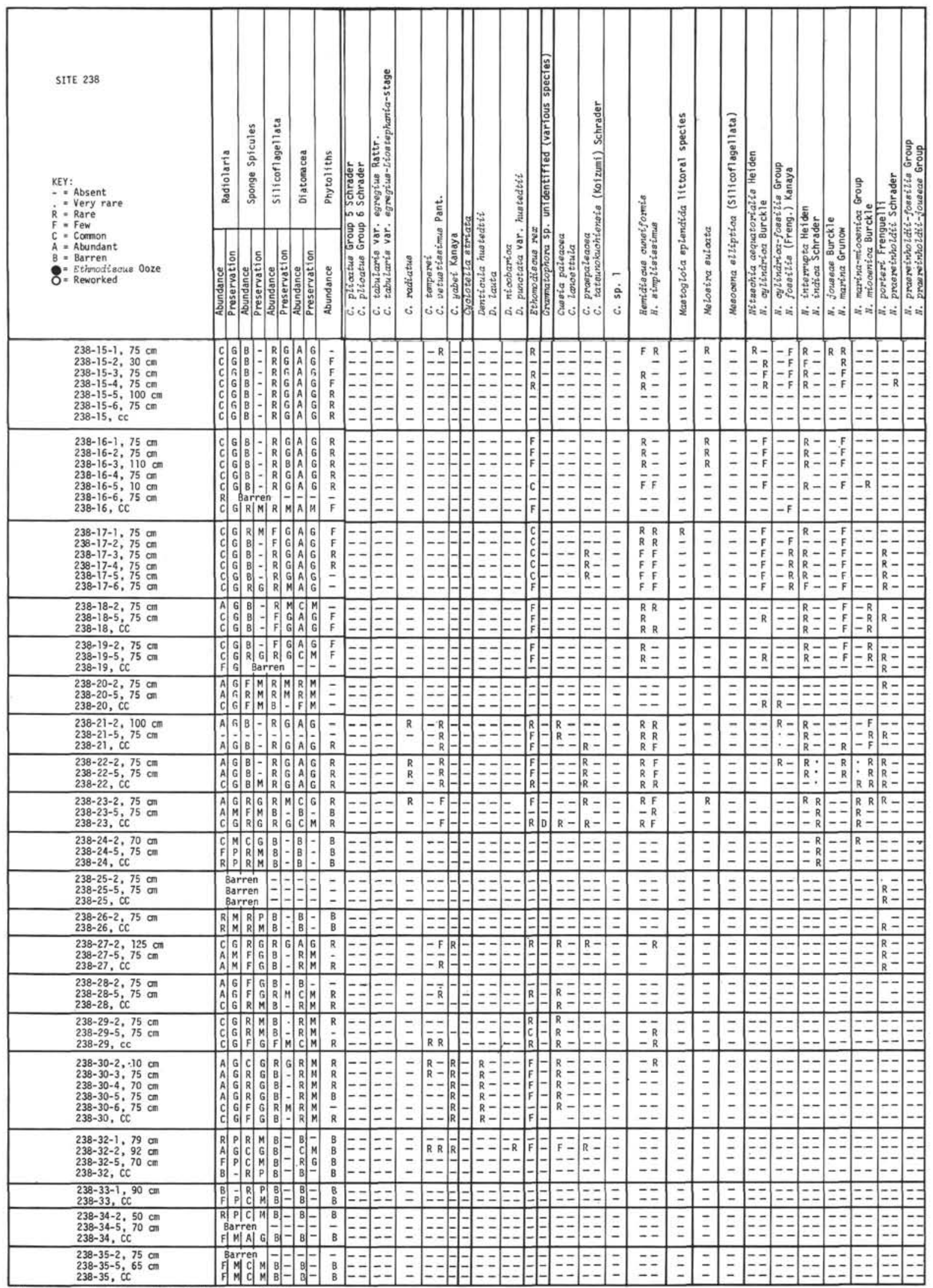


TABLE 2 - Continued

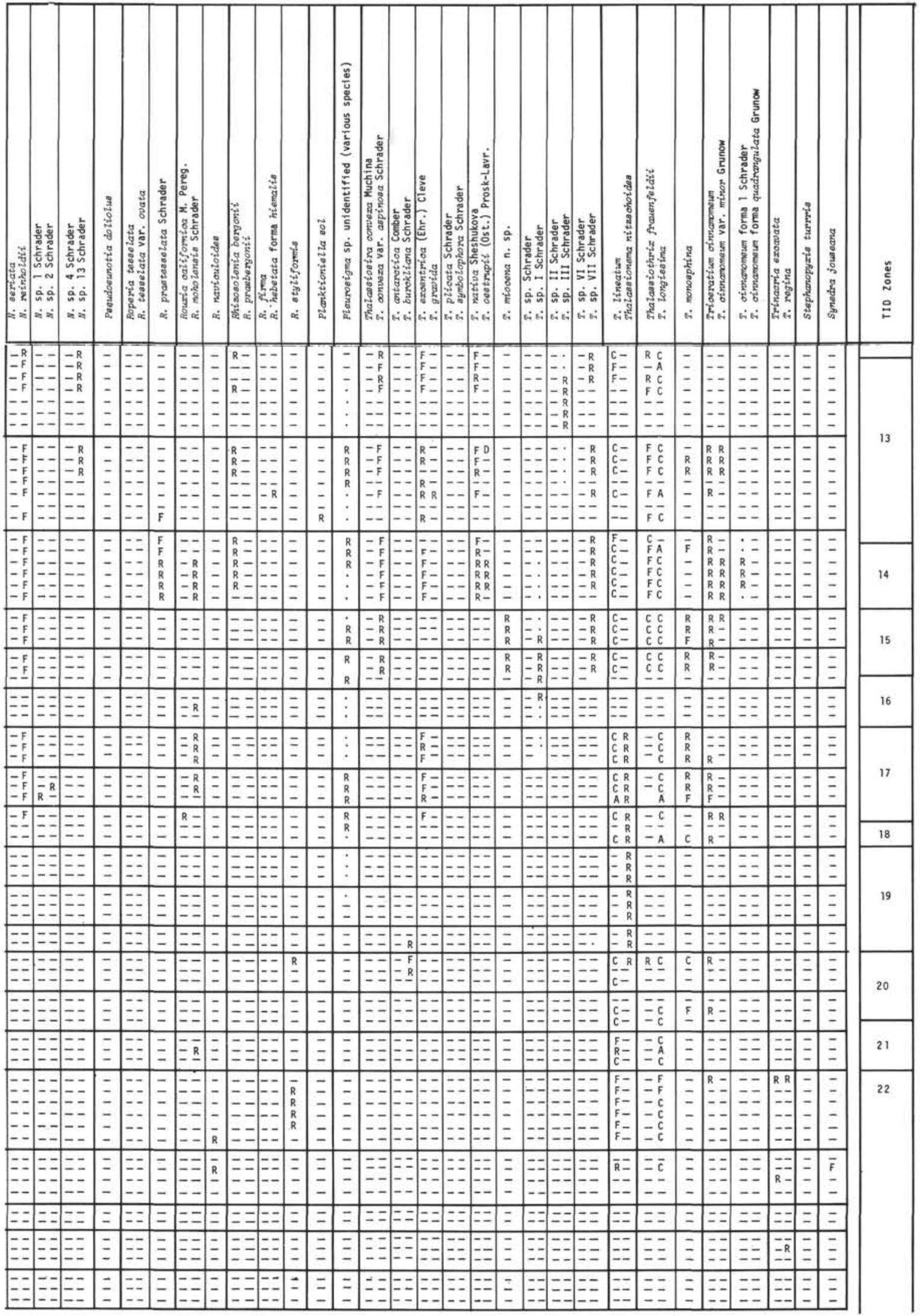


TABLE 3

Distribution of Diatoms and Other Siliceous Nannofossils, Site 213

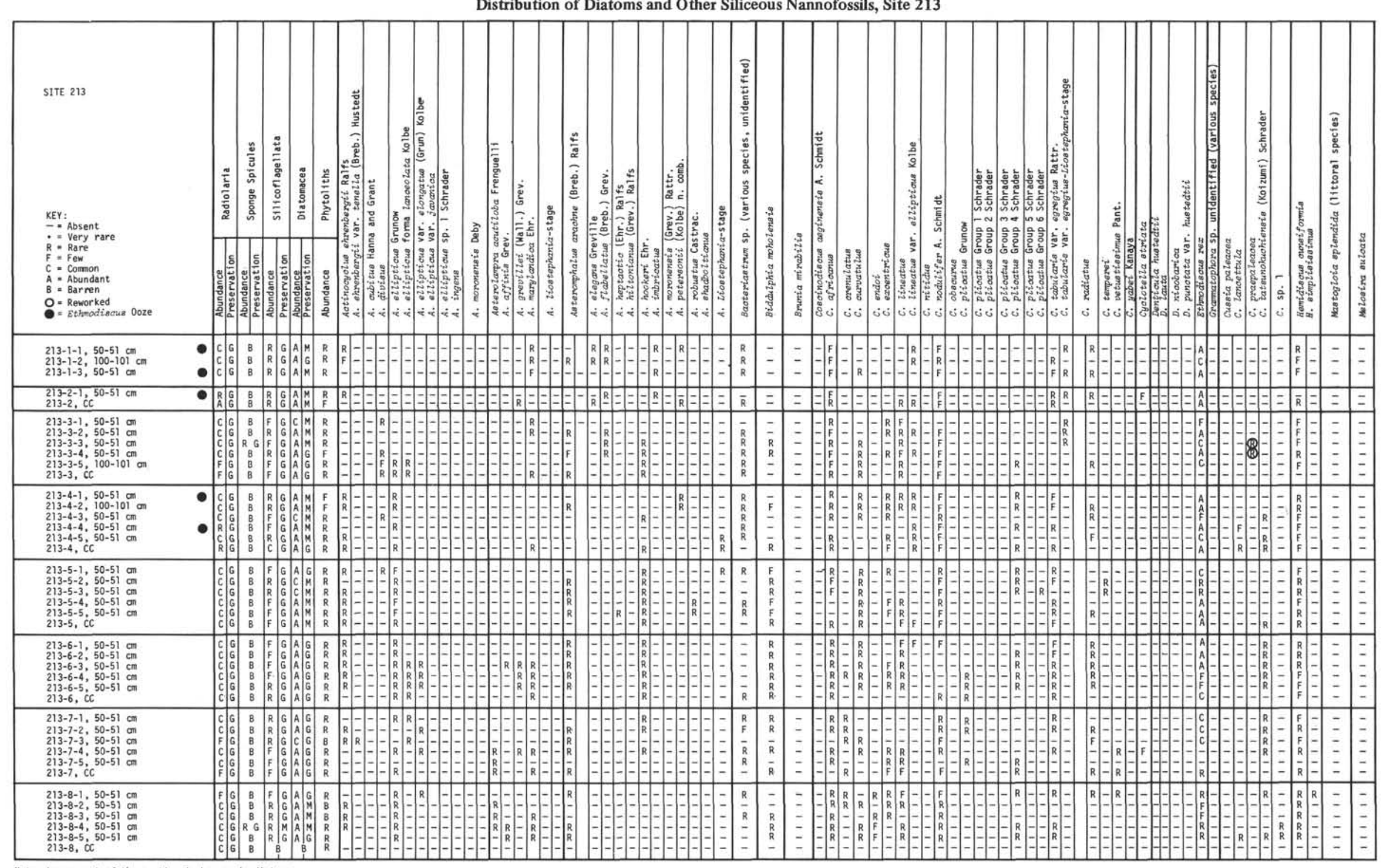


TABLE 3 - Continued

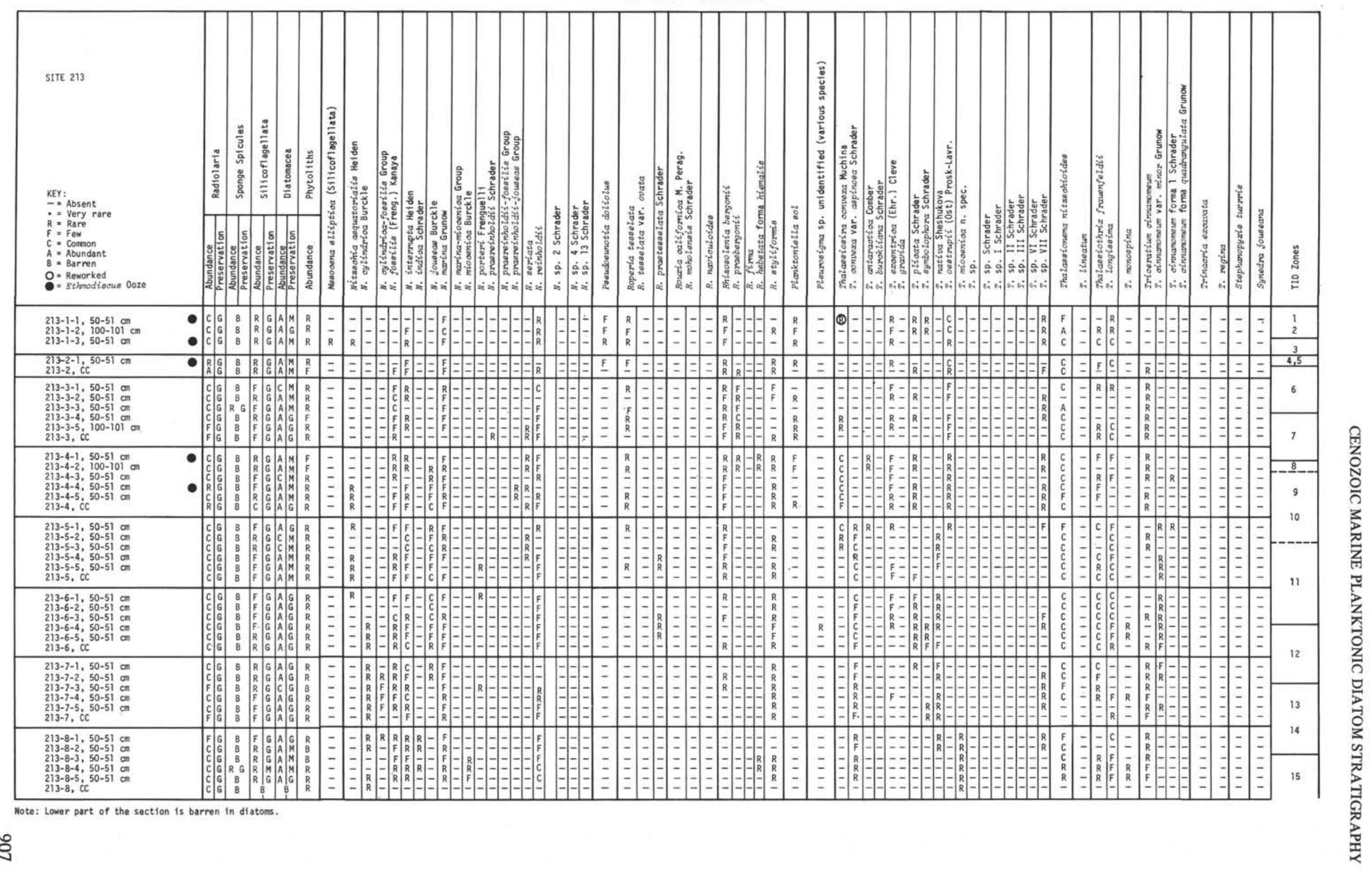


assemblage, but from the species composition, it can be suggested that no real cool period is represented. Reworked older fossils occur (sporadically) only in the upper part of the section. Only one horizon was found to represent Ethmodiscus ooze; this was at 2-1, 55-56 cm. Detailed references to the systematic composition of diatom floras are given in Table 4.

At this site, the base of the TID zones was observed to occur as follows:

TID Zone $1-4$ at 5 meters $(1-4,50-51 \mathrm{~cm})$

TID Zone 5 is at 17 meters $(2, \mathrm{CC})$

TID Zone 6 is at 17.5 meters $(3-1,50-51 \mathrm{~cm})$

TID Zone 7 is at 19 meters $(3-2,50-51 \mathrm{~cm})$

TID Zone 8 is at 22 meters $(3-4,50-51 \mathrm{~cm})$

TID Zone 9 is at 30 meters $(4-3,50-51 \mathrm{~cm})$

TID Zone $10-11$ is at 36.5 meters $(5-1,50-51 \mathrm{~cm})$

TID Zone 12 is at 39.5 meters $(5-3,50-51 \mathrm{~cm})$

TID Zone $13-14$ is at 47.5 meters $(6-2,100-101 \mathrm{~cm})$

TID Zone 15 has not been defined.

No breaks in the diatom stratigraphic record were detected. The recognition of tropical Indian Ocean diatom zones is tentative; this is a result of wide sample distance and/or by coring disturbance of soupy material.

Based on the placement of the base of Tropical Indian Ocean Diatom Zone 5 (Pliocene-Pleistocene boundary) between samples 2, CC and 3-1, 50-51 cm and other horizons with absolute age estimates, a sedimentation rate of $16.5 \mathrm{~m} / \mathrm{m} . \mathrm{y}$. can be calculated (Figure 11).

Correlation of TID zones at Sites 236, 238, 215, and 213 can be found in Figure 12.

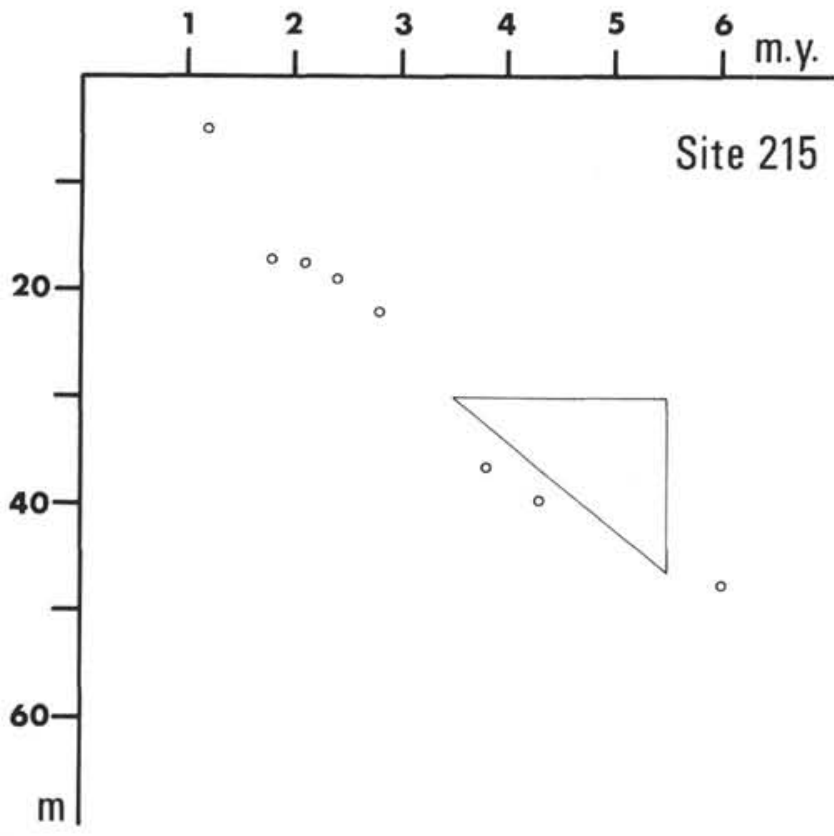

Figure 11. Sediment accumulation rate at Site 215.

\section{SYSTEMATIC, FLORAL SEQUENCE}

The genera are arranged alphabetically and species alphabetically within each genus. Species and varieties are treated according to the classifications of Hustedt $(1929,1959)$, Hendey $(1937,1964)$, Karsten (1907), Kanaya (1957, 1959), Koizumi (1968, 1972), Jousé (1971a), Schrader (1973a, 1973b, 1973c), Van Landingham (1967), Sheshukova-Poretzkaya (1967) and other whose descriptions have been followed strictly in identifying species.

New species have been described and their holotypes and paratypes designated. Holotypes are deposited in the authors type collection. Paratype material has been deposited at the Bundesanstalt für Bodenkunde, Hannover (L. Benda).

Unidentified species are numbered or grouped and illustrated and will be treated in a supplementary paper. An attempt was made to catalogue all diatom species in the samples. Almost all illustrated individuals are marked on the prepared slides with the aid of a diamond scribe (Schrader, 1974). In the synonomies of species that have previously been described, I have included, in most cases, only a reference to the original description and figure. Reference to a new combination is added; if the generic name now used differs; also a reference is added to the paper defining the present concept of the species.

The recently published paper of Bukry and Foster (1973) has not been treated taxonomically within this paper because of the misleading diatom taxonomy and genus concept used. It will be revised at a later date.

\section{Genus ACTINOCYCLUS Ehrenberg (1837)}

Actinocyclus cubitus Hanna and Grant (1926)

Description: Hanna and Grant, 1926, p. 118, pl. 11, fig. 3; Schrader, 1973a, pl. 19, fig. 7.

Occurrence: Very rare in the lower part of the section of Site 238 (TID Zone 20).

\section{Actinocyclus divisus (Grun.) Hustedt (1958)}

Description: Hustedt, 1958, p. 129-130, pl. 8, fig. 81; Hustedt, 1930 , p. 410 , fig. 218 (as Coscinodiscus divisus). This name was synonymized by Van Landingham (1967) p. 86 and he established a n. comb. Actinocyclus cholnokyi, unless the exact taxonomic position of Act. divisus Kisselev 1931 is not proven, I shall keep Hustedt's name.

Actinocylus ehrenbergii Ralfs in Pritchard (1861)

(Plate 19, Figure 18-19; Plate 21, Figures 16-17)

Description: Hustedt, 1929, p. 525, fig. 298.

Actinocyclus ehrenbergii var. tenella (Breb.) Hustedt (1929)

(Plate 20, Figure 1)

Description: Hustedt, 1929 , p. 530 , fig. 302 .

Actinocyclus ellipticus Grunow in Van Heurck (1883) (Plate 17, Figures 4, 5, 6-8, 16)

Description: Hustedt, 1929, p. 533, fig. 303; Van Heurck, 1883, pl. 124, fig. 10. I have placed all individuals under this name which do not possess a pseudonodulus in the middle of the valve except the marginal one, and which do possess a scattered middle structure.

Actinocyclus ellipticus var. elongatus (Grun.) Kolbe (1954)

(Plate 17, Figure 3)

Description: Kolbe, 1954 , p. 20 , pl. 3 , fig. 28,31 .

Actinocyclus ellipticus var. janvanicus Reinhold (1937) (Plate 17, Figure 13)

Description: Reinhold, 1937 ,p. 75, pl. 1, fig. 7-8.

Actinocyclus ellipticus forma lanceolata Kolbe (1954) (Plate 17, Figure 2)

Description: Kolbe, 1954, p. 20, pl. 3, fig. 27.

\section{Actinocyclus ingens Rattray (1890)}

Description: Kanaya, 1971 , p. 554 , numerous figures; Koizumi, 1968 , p. 207-208, pl. 32, fig. 5-6.

Occurrence: Occurs rarely in the lower part of the section of Site 238. 
TABLE 4

Distribution of Diatoms and Other Siliceous Nannofossils, Site 215

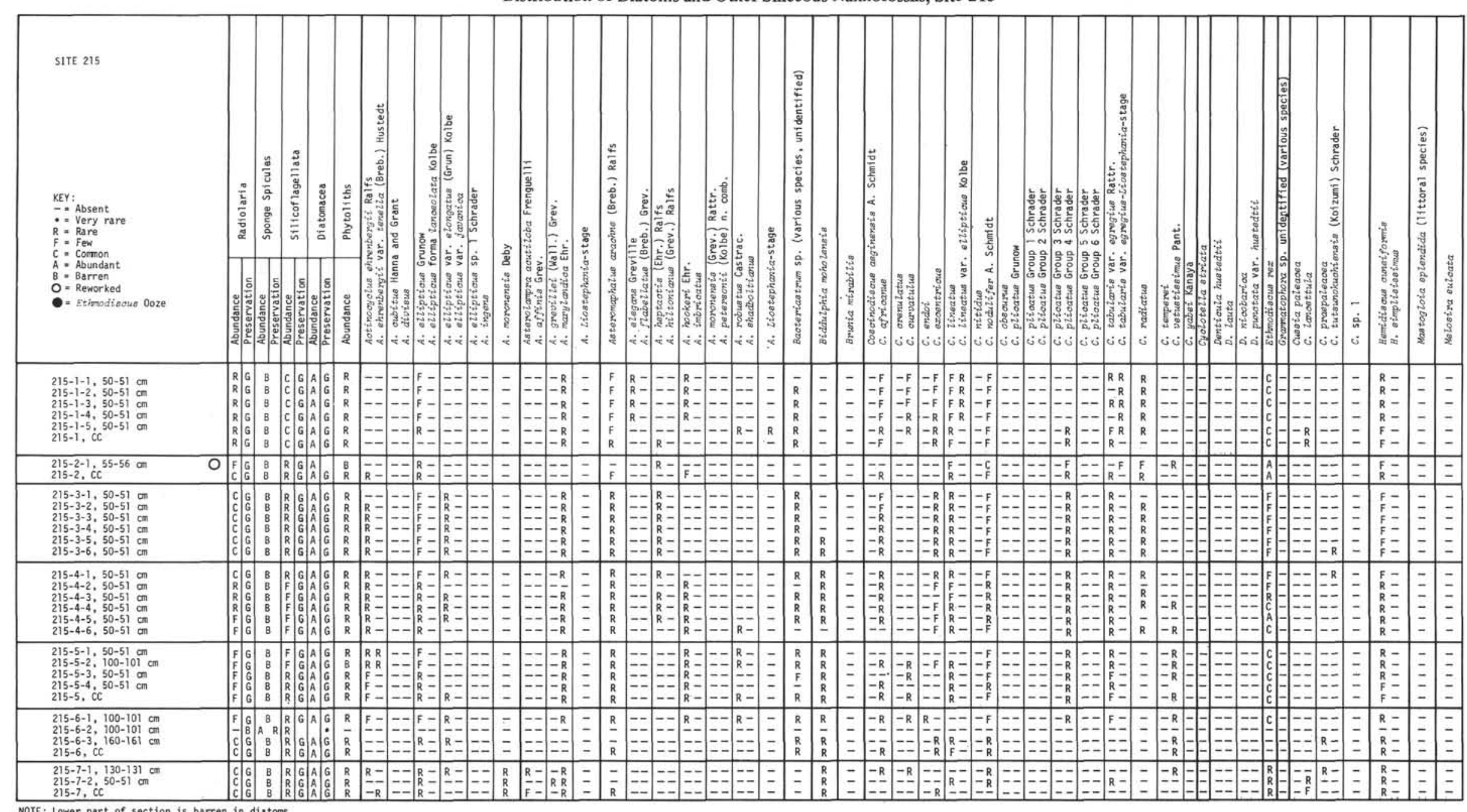


TABLE 4 - Continued

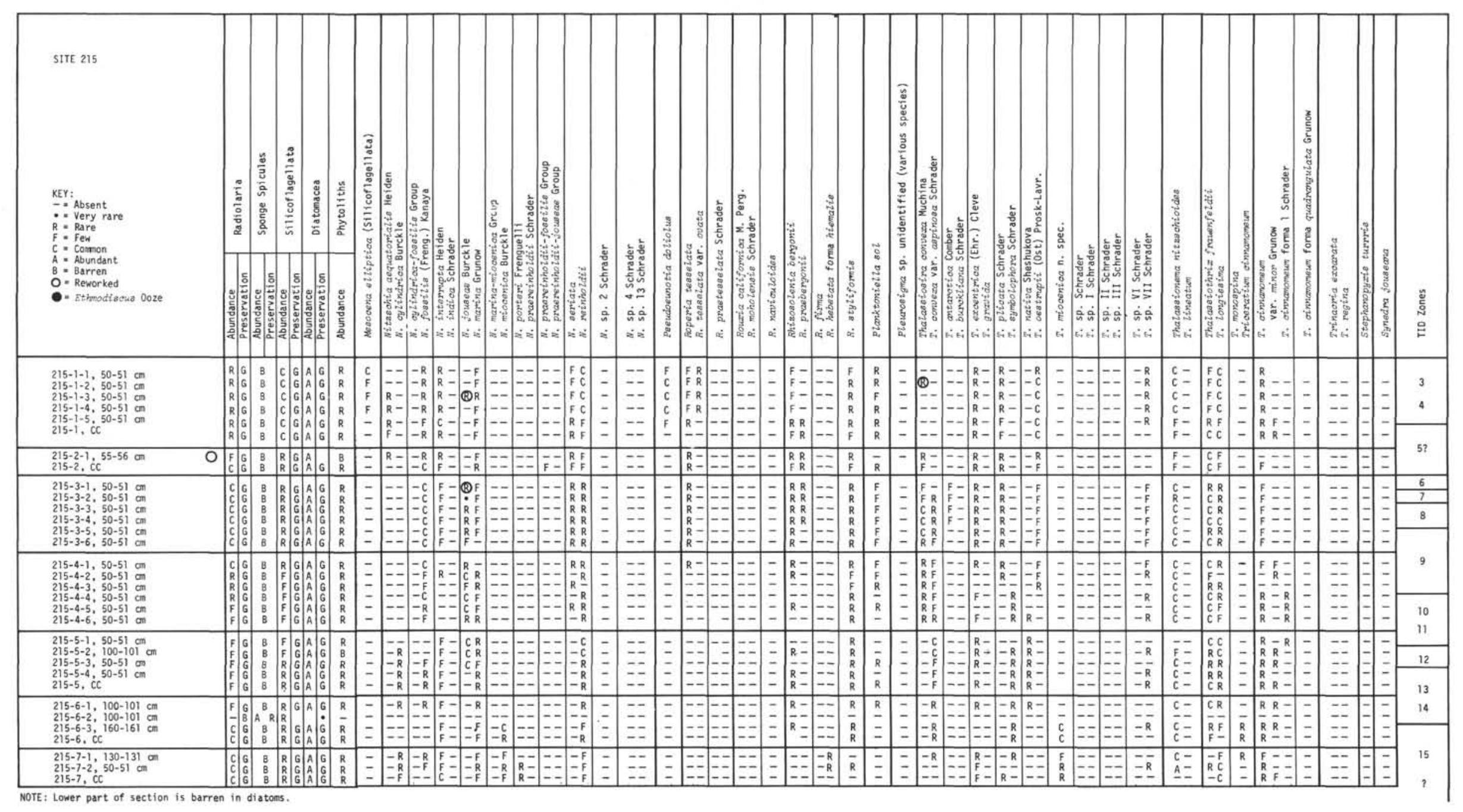




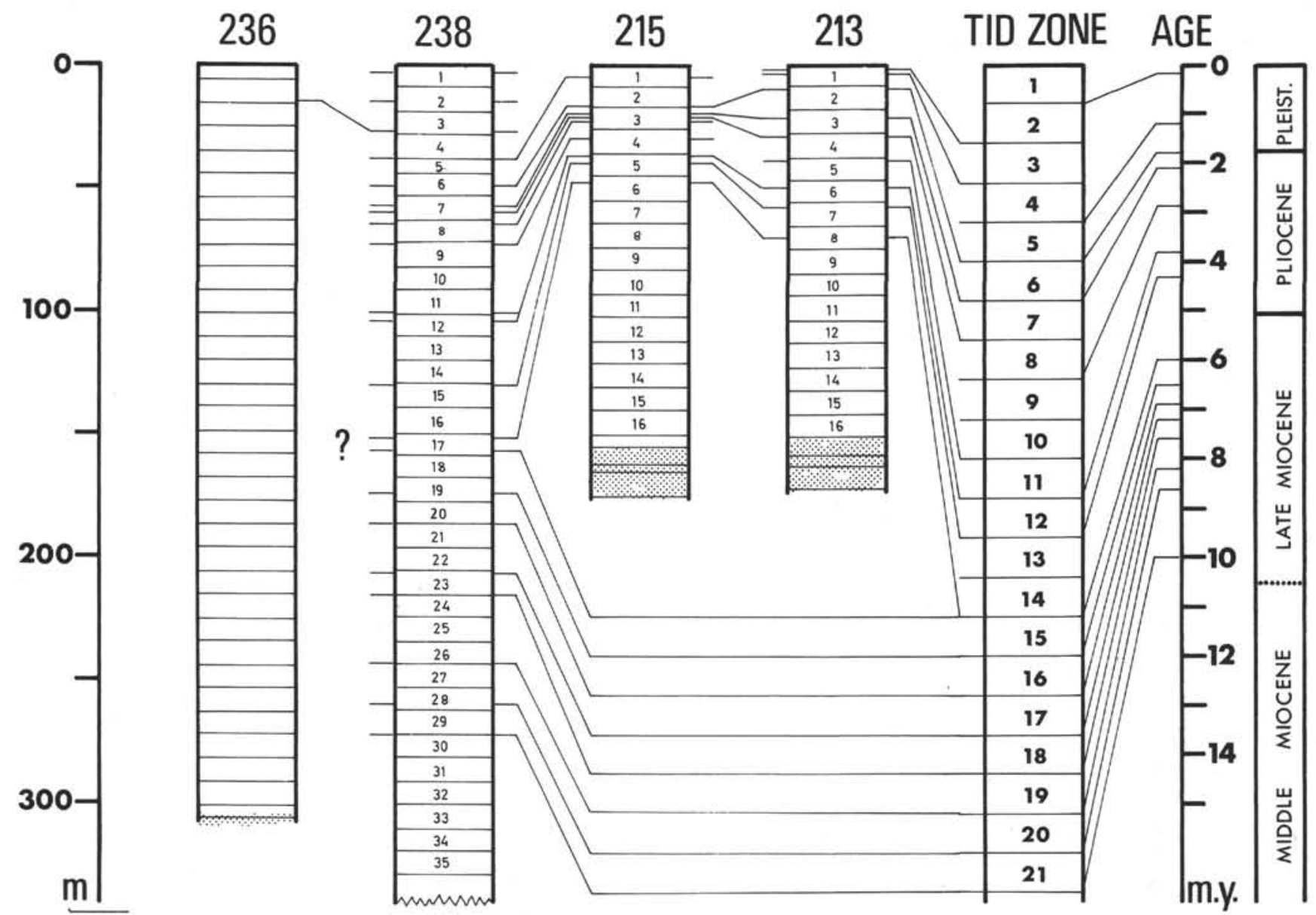

Figure 12. Correlation of Sites 236, 238, 215, and 213. Small numbers within the site columns are core numbers. Dotted areas at the base of the Site 236, 215 and 213 represent basalt. Site 238 has not been completely drawn.

Actinocyclus moronensis Deby in litt. Rattray (1890) (Plate 17, Figures 9-12)

Description: Rattray, 1890 , p. 195 ; Kolbe, 1954 , p. 21 , pl. 3 fig. 29-30 (as Actinoc. ellipticus var. moronensis). I have kept the original name of Deby because this species is different from Act. ellipticus in its characteristic middle structure and the regularly spaced marginal "labiate processes" which are absent from Act. ellipticus.

\section{Actinocyclus ellipticus sp. 1 Schrader}

(Plate 17, Figures 14-15; Plate 20, Figure 4)

Description: No similar species was observed in the literature. It differs from Actinocyclus ellipticus by the presence of a second pseudonodulus which is situated excentrically near the middle of the valve. Central area hyaline. All Act. ellipticus species need drastic taxonomic revision along with species being placed into the Triceratium cinnamomeum group.

\section{Actinocyclus sp. 1 Schrader \\ (Plate 21, Figure 18)}

Description: No similar species was observed in the literature. This species has a fasciculate structure with a pseudonodulus near the margin and half moon hyaline areas around the margin representing the areas where the labiate processes are inserted.

Occurrence: Rare in the upper part of the sections of Sites 238, 213 and 215 .

\section{Genus ANAULUS Ehrenberg (1844)}

Anaulus sp. 1

(Plate 19, Figure 1)

Only one specimen was observed. Accurate classification will be done at a later date.

\section{Genus ASTEROLAMPRA Ehrenberg (1844)}

\section{Asterolampra acutiloba Frenguelli in Tèmpere and Peragallo, 1912 \\ (Plate 9, Figures 7-8)}

Description: Schmidt et al., 1874, pl. 137, fig. 19 (unnamed); Forti in Tempère and Peragallo, 1912, p. 337, No. 696-698.

\section{Asterolampra affinis Greville (1862)}

(Plate 9, Figure 10)

Description: Schmidt, 1874 , pl. 137, fig. 4; Rattray, 1890, p. 649.

Asterolampra greville (Wallich) Greville (1860)

(Plate 8, Figure 5)

Description: Hustedt, 1929, p. 489, fig. 274. 
Asterolampra marylandica Ehrenberg (1844)

(Plate 8, Figure 2)

Description: Hustedt, 1929, p. 485, fig. 271.

\section{Asterolampra-Liostephania-Stage}

(Plate 12, Figures 22-23)

For reference see Hanna and Brigger, 1970; Kolbe, 1954, p. 39. For more detail see under section "Ethmodiscus ooze".

\section{Genus ASTEROMPHALUS Ehrenberg (1845)}

Asteromphalus arachne (Breb.) Ralfs in Pritchard (1861) (Plate 9, Figure 11)

Description: Hustedt, 1929, p. 493, fig. 276.

\section{Asteromphalus brookei Bailey (1856)}

Description: Rattray, 1890 , p. 657 ; illustration Schmidt et al., 1874 , pl. 38, fig. 21-23.

Occurrence: Rare in TID Zones 1-5, Sites 238, 213.

\section{Asteromphalus elegans Greville (1859)}

(Plate 8, Figure 4)

Description: Hendey, 1937, p. 269; illustration Schmidt et al., 1874, pl. 38, fig. 1-2.

Occurrence: Rare in TID Zones 1-4, Sites 238, 213, 215.

\section{Asteromphalus flabellatus (Breb.) Greville (1859)}

(Plate 8, Figure 3)

Description: Hustedt, 1929, p. 498, fig. 279; Schmidt et al., 1874 , pl. 38 , fig. 10-12.

Occurrence: Rare in TID Zones 1-4, Site 238.

\section{Asteromphalus heptactis (Breb.) \\ Ralfs in Pritchard (1861) \\ (Plate 8, Figure 1)}

Description: Hustedt, 1929, p. 494, fig. 277.

\section{Asteromphalus hiltonianus (Greville)}

Ralfs in Pritchard (1861)

Description: Ralfs in Pritchard, 1861 , p. 837; illustration Greville, 1860, p. 117, pl. 4, fig. 15 .

\section{Asteromphalus hookeri Ehrenberg (1844) \\ (Plate 8, Figure 7)}

Description: Hendey, 1937, p. 270; illustration Ehrenberg, 1844 , pl. (June), fig. 3 ,

\section{Asteromphalus imbricatus Wallich (1860)}

Description: Ralfs in Pritchard, 1861, p. 837.

Occurrence: Rare in TID Zones 1-3, Site 213.

\section{Asteromphalus moronensis (Greville)}

$$
\text { A. Schmidt (1876) }
$$

Description: Greville, 1863, p. 230, pl. 9, fig. 8; Hanna and Grant, 1926, p. 126, pl. 13, fig. 2 (as Ast. dubius Hanna and Grant).

Occurrence: Very rare in the lower part of the section, Site 238 (TID Zones 15-20).

\section{Asteromphalus petersonii (Kolbe) n. comb.} (Plate 12, Figures 10-13)

Synonyms: Liriogramma petersonii Kolbe, 1954, p. 40, fig. 9; Liriogramma hustedtii Kolbe, 1955, p. 173, fig. 6.

Description: Kolbe, 1954 , p. 40 , fig. 9; 1955 , p. 173 , fig. 6 . Individuals with complete intact structures were observed and revealed that Kolbe's genus Liriogramma has to be synonymized with Asteromphalus (compare Plate 12, Figures 10-13). The more the gradiant of ghost shape of original structure the more individuals look like "Liriogramma hustedtii" and vice versa.

\section{Asteromphalus robustus Castracane (1875)} (Plate 8, Figure 6)

Description: Hustedt, 1929, p. 496, fig. 278.

\section{Asteromphalus shadboltianus (Greville)} Ralfs in Pritchard (1861)

Description: Ralfs in Pritchard, 1861, p. 838; illustration Schmidt et al., 1874, pl. 38, fig. 17 and pl. 137, fig. 26 .

\section{Asteromphalus Liostephania Stage}

(Plate 12, Figures 16-19)

For reference see Hanna and Brigger, 1970; Kolbe, 1954, p. 39. For more detail see under section "Ethmodiscus ooze".

$$
\begin{aligned}
& \text { Asteromphalus spec. } 1 \\
& \text { (Plate 9, Figures 12-13) }
\end{aligned}
$$

No similar specimens were found in the literature.

\section{Genus BACTERIASTRUM Shadbolt (1853)}

\section{Bacteriastrum species}

Various fragments of this genus were found in the Pleistocene to Pliocene sections of Sites $213,215,238$. Exact identification is only possible if whole chains with middle and end cells are present.

\section{Genus BIDDULPHIA Gray (1821)}

Biddulphia moholensis Schrader (1974)

(Plate 19, Figures 2-3)

Description: Schrader, 1974, p. 534, pl. 4, fig. 3-4.

\section{Genus BRUNIA Tèmpère (1890) \\ Brunia mirabilis (Brun in Brun and Tèmpère) Tèmpère (1890)}

Description: Brun in Brun and Tèmpère, 1889 , p. $27, \mathrm{pl} .8$, fig. 1. Schrader, 1973a, pl. 13, fig. 16.

Occurrence: Rare in the lower part of the section of Site 238.

\section{Genus CHAETOCEROS Ehrenberg (1844)}

\section{Chaetoceros species}

In many samples, representing a well-preserved diatom assemblage, numerous Chaetoceros fragments (mainly bristles) were observed. These bristles could be assigned in some cases to the following species: Chaetoceros peruvianus Brightwell; Chaetoceros compressus Lauder, Chaetoceros messanensis Castracane a.o. There are about a dozen other fragments which could not be assigned to a specific Chaetoceros species.

\section{Genus COSCINODISCUS Ehrenberg (1838) \\ Coscinodiscus aeginensis Schmidt (1888) in Schmidt et al. (1874)}

Description: Hanna, 1932, p. 178, pl. 5, fig. 9; Schmidt et al., 1874, pl. 113, fig. 13-14.

Occurrence: Rare in samples from Site 238; TID Zones 18-20.

$$
\begin{gathered}
\text { Coscinodiscus africanus Janisch (1878) } \\
\text { in Schmidt et al. (1874) } \\
\text { (Plate 18, Figures 1-2) }
\end{gathered}
$$

Description: Hustedt, 1928, p. 428, fig. 231. 
Coscinodiscus crenulatus Grunow (1884)

Description: Hustedt, 1928, p. 411, fig. 219.

\section{Coscinodiscus curvatulus Grunow (1878)} in Schmidt et al. (1874-)

Description: Hustedt, 1928, p. 406, fig. 214.

\section{Coscinodiscus endoi Kanaya (1959)}

(Plate 18, Figures 5-7)

Description: Kanaya, 1959 , p. 76 , pl. 3, fig. 8-11; Schrader, 1973a, pl. 7, fig. 14,21 ; pl. 20, fig. 1-2.

\section{Coscinodiscus excentricus Ehrenberg (1839) \\ (Plate 11, Figures 5, 9-11; \\ Plate 14, Figures 1-2, 8)}

Description: Hustedt, 1928 , p. 388 , fig. 201. I have placed all individuals with a typical Cosc. excentricus structure and without a central strutted tubulus into Coscinodiscus and all with a central strutted tubulus into Thalassiosira.

\section{Coscinodiscus gigas var. diorama (Schmidt) Grunow (1884) \\ ((?) Plate 18, Figure 8)}

Description: Rattray, 1890 , p. 542 ; Schmidt et al., 1874 , pl. 64 , fig. 2 .

\section{Coscinodiscus lineatus Ehrenberg (1838) (Plate 11, Figure 6)}

Description: Hustedt, 1928, p. 392, fig. 204

\section{Coscinodiscus lineatus var. ellipticus Kolbe (1954)}

(Plate 10, Figures 5-8)

Description: Kolbe, 1954 , p. 32, pl. 2, fig. 15.

Occurrence: Rare to few in the upper sections. This species is most characteristic and can easily be recognized by its tangential plication and the fine marginal structure.

\section{Coscinodiscus nitidus Gregory (1857)}

Description: Hustedt, 1928, p. 414, fig. 221.

Occurrence: Present in samples with shallow-water material influx. $C$. nitidus is common in nearshore environments, possibly as a benthic marine species.

\section{Coscinodiscus nodulifer Schmidt in Schmidt et al. (1874-).}

Description: Hustedt, 1930 , p. 426, fig. 229.

\section{Coscinodiscus obscurus Schmidt} in Schmidt et al. (1874-)

Description: Hustedt, 1928, p. 418, fig. 224.

Occurrence: Found in varying numbers at Sites 238, 215, 213.

\section{Coscinodiscus plicatus Grunow (1878)} in Schmidt et al. (1874-)

(Plate 15, Figures 21-22; Plate 16, Figures 9-15; Plate 21, Figures 1-2, 5-7)

Description: Grunow, 1884 , p. 86 , pl. 3, fig. 10, 27; Kolbe, 1954 , p. 34-35 (no illustration); Schrader, 1973a, pl. 6, fig. 23.

The following species have been grouped preliminary to Cosc. plicatus and are numbered. The whole Cosc. plicate-Group will be treated taxonomically in a separate paper.

Coscinodiscus plicatus Group 1

Coscinodiscus plicatus Group 2
Coscinodiscus plicatus Group 3

Coscinodiscus plicatus Group 4

Coscinodiscus plicatus Group 5

Coscinodiscus plicatus Group 6

\section{Coscinodiscus radiatus Ehrenberg (1839)}

Description: Hustedt, 1929, p. 420 , fig. 225.

Occurrence: Rare to common in most samples.

\section{Coscinodiscus symbolophorus Grunow (1884)}

Description: Hustedt, 1919, p. 396-398, fig. 208 (as Coscinodiscus stellaris var. symbolophora (Grunow) Jörgensen; Schrader, 1973a, pl. 22, fig. 8-9.

Occurrence: Very rare in the lower part of the section of Site 238.

\section{Coscinodiscus tabularis var. \\ Egregius-Liostephania-Stage (Plate 12, Figures 1-9)}

Similar to the Liostephania-stage of the genera Asteromphalus and Asterolampra.

\section{Coscinodiscus tabularis var. egregius}

$$
\text { (Rattray) Hustedt (1930) }
$$

(Plate 12, Figures 1, 9; Plate 18, Figures 3-4, 9; Plate 19, Figure 10a)

Description: Hustedt, 1930 , p. 428 , fig. 230 b.

\section{Coscinodiscus temperei Brun}

in Brun and Tempere (1889)

Description: Kanaya, 1959, p. 84, pl. 4, fig. 8; Schrader, 1973a, pl. 6 , fig. $18-19$, pl. 7 , fig. 1-5, 8-9.

\section{Coscinodiscus vetustissimus Pantocsek (1886)}

Description: Pantocsek, 1886, p. 71, pl. 20, fig. 186; Hustedt, 1929; p. 412, fig. 220.

\section{Coscinodiscus yabei Kanaya (1957) (Plate 21, Figure 8)}

Description: Kanaya, 1957, p. 86, pl. 5, figs. 6-9; Schrader, 1973a, pl. 6, figs. 1-6.

\section{Genus CYCLOTELLA Kützing (1834)}

\section{Cyclotella striata (Kützing)|Grunow} in Cleve and Grunow (1880)

Description: Hustedt, 1928 , p. $344-347$, fig. 176. Littoral marine species. Occurrence as displaced individuals in marine hemipelagic sequences.

\section{Genus DENTICULA Kützing (1884)}

Denticula husted tii Simonsen and Kanaya (1961)

(Plate 18, Figures 10-11)

Description: Simonsen and Kanaya, 1961, p. 501, pl. 1, fig. 19-25; Schrader, 1973a, pl. 2, fig. 28-34, 36-47.

\section{Denticula lauta Bailey (1854)}

Description: Simonsen and Kanaya, 1961, p. 500-501, pl. 1, fig. 1-8; Schrader 1973a, pl. 2, fig. 14-25, 35. 


\section{Denticula nicobarica Grunow (1868)}

Description: Simonsen and Kanaya, 1961, p. 503, pl. 1, fig. 11-13; Schrader, 1973b, p. 419-420, pl. 1, fig. 25-27.

\section{Denticula punctata var. hustedtii Schrader (1973a)}

Description: Schrader, 1973a, p. 705, pl. 1, fig. 23-24; Schrader, 1973 b, p. 420 , pl. 1 , fig. 18

\section{Genus ETHMODISCUS Castracane (1886)}

\section{Ethmodiscus rex (Rattray) Hendey (1953) in Hendey and Wiseman}

Description: Hendey and Wiseman, 1953, p. 51-57, pl. 1, fig. $1-6$, pl. 2, fig. 1-3.

\section{Genus GRAMMATOPHORA Ehrenberg (1839)}

\section{Grammatophora species}

Species of the genus Grammatophora occurred in rare numbers within those intervals bearing other displaced littoral marine benthic species. In most cases, only intercalary bands were found which do not permit a taxonomic treatment (Hendey, 1964).

\section{Genus CUSSIA n. gen.}

Synonyms: Coscinodiscus e.p. Rattray, 1890, p. 597, fig. 149; Stoschia (?) e.p. Grunow in Van Heurck, 1883, pl. 128, fig. 6; Coscinodiscus e.p. Schrader, 1973a, (paleaceus, praepaleaceus); Rhaphoneis e.p. Hajos, 1968, p. 143, pl. XLI, fig. 16-27; Rhaphoneis e.p. Koizumi, 1972, p. 349, pl. 42, fig. 3-4.

Description: Cells solitary, free. Valves elliptical lanceolate with a symmetrical and/or asymmetrical transapical axis, flat. Valve surface usually either areolate, areolae round or with transapical costae forming a pennate like surface ornamentation with a zig-zag apical costa forming a "pseudoraphe"-like morphological band, in between the costae hyaline intercostal membranes. Valve center not furnished with a central area. Spines or apiculi absent. Valve margin usually narrow with a coarse striation.

Generotype: Stoschia (?) paleacea Grunow in Van Heurck, 1883 , pl. 128 , fig. 6 .

Distribution: Widely distributed in Neogene marine sediments (Pacific, Mediterranean Sea, Atlantic, Indian Ocean).

Discussion: Stoschia Janisch in litt, was not validly published by Janisch, but was distributed privately to diatomists by the author (Janisch: C.: The diatoms of the Gazelle Expedition, 17 plates with m.s. index, no date). Rattray, 1890 , p. 548, combined Stoschia with Coscinodiscus and combined the species Stoschia admirabilis Janisch (ca. 1888) with Coscinodiscus reniformis Castracane (1886, p. 160, pl. 12, fig. 12). Grunow (1883 in Van Heurck) established the species Stoschia paleacea; this species was newly combined by Rattray (1890, p. 597, fig. 149) and named Coscinodiscus paleaceus (Grunow) Rattray. As soon as the evolution of the genus under discussion was revealed, the taxonomic position of some other species could be detected which have been described under Rhaphoneis by Hajos (1968) and Koizumi (1972).

Derivatio nominis: Dedicated to the scientific vessel Cuss I, which drilled the Experimental Mohole Drilling.

\section{Cussia lancettula n. sp. \\ (Plate 19, Figures 14-16)}

Description: Valves elliptical-lanceolate with acute rounded ends. 24-70 $\mu$ long, 4-7 $\mu$ wide. Transapical axis symmetrical. Valve surface flat with transapical costae, $12-10$ in $10 \mu$ slightly curved near the apices. Transapical costae not divided in the middle part, divided towards the apices and here in decussate arrangement, connected in the middle by an apical zig-zag line which simulate a pseudoraphe. Intercostal membranes homogenous even in oblique light. Margin not separated from the valve structure.

Discussion: This species differs from Cussia praepaleacea by the margin not being separated, and by the simple transapical structure.

Derivatio nominis: lancea (latin) - lance

Holotype: Plate 1, figures 9-10 in Schrader (1974) from EMD-8-15-100/101 cm, a sample from North Pacific Diatom Zone
19. California Academy of Sciences, Geology Catalog (diatom collection) No. 54411.

Paratype: Plate 1, figure 5 in Schrader (1974). California Academy of Sciences, Geology Catalog (diatom collection) No. 54412.

Cussia paleacea (Grunow) n. comb.

Basionym: Stoschia paleacea Grunow in Van Heurck, 1883, pl. 128 , fig. 6 .

Synonyms: Coscinodiscus paleaceus (Grunow) Rattray, 1890, p. 597, fig. 149; Coscinodiscus paleaceus (Grunow) Rattray, in Schrader, 1973a, p. 703, pl. 3, figs. 10-12.

Description: Kolbe, 1954 , p. 34, pl. 3, fig. 32.

Cussia praepaleacea (Schrader) n. comb.

Basionym: Coscinodiscus praepaleaceus Schrader, 1973a, p. 703, pl. 3, fig. 1.

Description: Schrader, 1973a, p. 703, pl. 3, figs. 1-9.

Cussia tatsunokuchiensis (Koizumi) n. comb.

Basionym: Raphoneis tatsunokuchiensis Koizumi, 1972, p. 349, pl. 42, fig. 3-4.

Description: Koizumi, 1972 , p. 349 , pl. 42 , fig. $3-4$.

Cussia sp. 1

(Plate 18, Figure 12)

Description: This species is placed with hesitation into the genus Cussia and was found only in one single frustule. It has a lanceolate valve with acute apices. Structure is arranged in transapical lines; no middle structure line is present. Unless more individuals have been found no taxonomic decision will be made.

\section{Genus HEMIDISCUS Wallich (1860) \\ Hemidiscus cuneiformis Wallich (1860) (Plate 19, Figures 20-25)}

Description: Hustedt, 1930, p. 904-907, fig. 542 .

Hemidiscus simplicissimus Hanna and Grant (1926)

Description: Hanna and Grant, 1926, p. 147, pl. 16, fig. 13; Schrader, 1973a, p. 706, pl. 24, fig. 12-13.

\section{Genus MASTOGLOIA Thwaites in Smith (1856) Mastogloia species}

Various species of this characteristic genus were found, among others, $M$. splendida. All encountered individuals belong to marine littoral benthic species and are displaced into this depositional environment.

\section{Genus MELOSIRA Agardh (1824) \\ Melosira sulcata (Ehr.) Kützing (1844)}

Description: Hustedt, 1928, p. 276-278, fig. 118-119. Littoral marine species; often found displaced with open ocean plankton.

\section{Genus NITZSCHIA Hassal (1845)}

Nitzschia aequatorialis Heiden in Heiden and Kolbe (1927)

Description: Heiden and Kolbe, 1927, p. 665 , pl. 7, fig. 149; Kolbe 1955, p. 174, pl. 2, fig. 24.

\section{Nitzschia cylindrica Burckle (1972) (Plate 6, Figures 26-34, 36-38)}

Description: Burckle, 1972, p. 239-240, pl. 2, fig. 1-6.

$$
\begin{gathered}
\text { Nitzschia fossilis (Frenguelli) Kanaya in } \\
\text { Kanaya and Koizumi (1970) } \\
\text { (Plate 6, Figures 8-18, 19-20 (?), 21-22) }
\end{gathered}
$$




\section{Nitzschia kolaczeckii Grunow (1967)}

Description: Kolbe, 1955, p. 174, pl. 2, fig. 22-23; Hustedt in Schmidt et al., 1874 , pl. 349, fig. 38-39.

Occurrence: Found in rare numbers in the upper Pliocene to Pleistocene section of Site 238

\section{Nitzschia indica n. sp.}

Description: Valves elliptical with slightly convex margins and acute, broadly rounded apices. $40-70 \mu$ long, $8-11 \mu$ wide in the middle of the valve. Transapical costae $11-12$ in $10 \mu$. Intercostal membrane with two rows of rounded pores in decussate arrangement, approximately 20 pores in $10 \mu$. Transapical costae and intercostal structures straight transapical, slightly curved at the apices. Two inner apical lines parallel to the margin, but approximately $3 \mu$ from the margin forming the borders of the inner pore margins. Pore longitudinal in transapical direction approximately $4 \mu$ wide in the middle of the valve, becoming gradually smaller towards the apices. Raphe marginal, with bent in (like in Nitzschia marina) raphe pols at the apices. Keel strong approximately $1-1,5 \mu$ wide, about 12 keel-punctae in $10 \mu$. In the middle of the valve a marginal enlarged and well detectable central nodule, approximately $2 \mu$ wide in apical direction. Valve surface almost flat becoming gradually convex near the margins and near the apices.

Discussion: This species is close to Nitzschia miocenica and Nitzschia marina but differs by the presence of a central nodule and by the central line of broad inner rectangular pores.

Holotype: Plate 5, Figures 16-17 from DSDP Leg 24, 238-23, CC, tropical Indian Ocean. Collection Schrader.

\section{Nitzschia interrupta Heiden}

in Heiden and Kolbe (1927)

(Plate 15, Figures 1-7, 8-9 (?) 10-11)

Description: Heiden and Kolbe, 1927, p. 665 , pl. 7, fig. 150; Kolbe, 1955, p. 174, pl. 2, fig. 25-27.

\section{Nitzschia jouseae Burckle (1972) \\ (Plate 7, Figures 14-23)}

Description: Burckle, 1972, p. 240, pl. 2, fig. 17-21.

Nitzschia marina Grunow in Cleve and Grunow (1880)

(Plate 5, Figures 1-2, 5, 14-14 (?))

Description: Grunow in Cleve and Grunow, 1880, p. 70.

Nitzschia miocenica Burckle (1972)

(Plate 5, Figures 10-11)

Description: Burckle, 1972, p. 240-241, pl. 2, fig. 10-15.

Nitzschia porteri Frenguelli (1949)

(Plate 15, Figure 14)

Description: Frenguelli, 1949, p. 116, pl. 1, fig. 33-34.

Nitzschia praereinholdii Schrader (1973a) (Plate 7, Figures 24-26)

Description: Schrader, 1973a, p. 708, pl. 5, fig. 20-26.

Nitzschia reinholdii Kanaya and Koizumi (1970)

(Plate 5, Figures 3-4, 6-9, 12-13, 18-19; Plate 7, Figures 10-11)

Description: Schrader, 1973a, p. 708, pl. 4, fig. 12-16.

\section{Nitzschia seriata Cleve (1883)}

Description: Cleve, 1883, p. 478 , pl. 38 , fig. 75 ; Hasle, 1972, p. 176-179, fig. 2.

Occurrences: Found in rare numbers in the upper Pliocene to Pleistocene sections of Sites 238, 215, 213.
Only those Nitzschia species which could definitively be determined have been treated taxonomically. All the following forms must be studied in more detail in the near future. They represent, among others, transitional forms between species and are placed into groups representing morphological characters of one or the other of the listed species. Final decision will be published in a comprehensive paper (in preparation) on evolutionary trends and "events", together with a revised taxonomy of marine-fossil Nitzschia species.

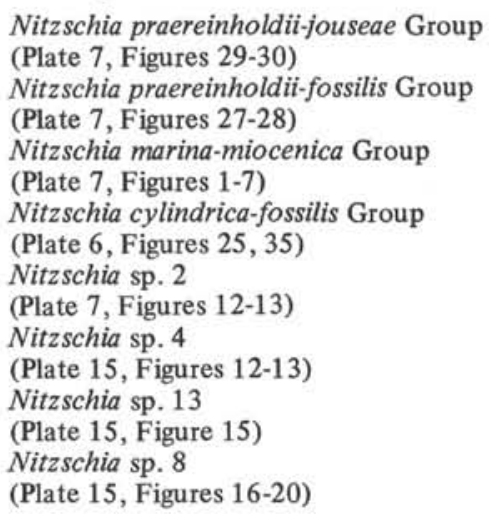

Genus PLANKTONIELLA Schütt (1893)

Planktoniella sol (Wallich) Schütt (1893)

Description: Hustedt, 1930, p. 465-467, fig. 259; Gerloff, 1970 , p. $203 \mathrm{ff}$.

\section{Genus PLEUROSIGMA Wm. Smith (1852) \\ Pleurosigma species}

A small number of Pleurosigma species were found in the well-preserved diatomaceous samples. It is not possible at the moment to identify these individuals.

Genus PSEUDOEUNOTIA Grunow in Van Heurck (1880)

Pseudoeunotia doliolus (Wallich)

Grunow in Van Heurck (1880)

(Plate 6, Figures 1-7)

Description: Hustedt, 1959, p. 258-260, fig. 737.

$$
\begin{gathered}
\text { Genus RHIZOSOLENIA Ehrenberg (1841) } \\
\text { Rhizosolenia bergonii Peragallo (1892) } \\
\text { (Plate 9, Figure 4) }
\end{gathered}
$$

Description: Hustedt, 1930, p. 575-577, fig. 327.

Rhizosolenia firma Karsten (1907)

$$
\text { (Plate 9, Figure 6) }
$$

Description: Karsten, 1907 , p. 377 , pl. 41, fig. 2; Hustedt, 1930, p. 574-575, fig. 326; Kolbe, 1957, p. 41, pl. 4, fig. 52.

\section{Rhizosolenia hebetata forma hiemalis Gran (1904) (Plate 9, Figure 5)}

Description: Hustedt, 1930, p. 590-592, fig. 337.

$$
\begin{gathered}
\text { Rhizosolenia praebergonii Muchina (1965) } \\
\text { (Plate 9, Figures 1-3) }
\end{gathered}
$$

Description: Koizumi, 1968 , p. 217 , pl. 34 , fig. 20-21.

\section{Rhizosolenia styliformis Brightwell (1858)}

Description: Hustedt, 1930, p. 584-588, fig. 333-335.

$$
\text { Genus ROPERIA Grunow in Van Heurck (1881) }
$$$$
\text { Roperia praetesselata n. sp. }
$$

Description: Valves circular, surface flat, valve mantle-abrupt. $25-30 \mu$ in diameter. Valve surface covered with hexagonal areola- 
tions arranged in transverse decussating lines in the middle part of the valve up to about half radius (about 8 areolae in $10 \mu$ ), from thence to the margin in radiating fascicles. Areolae decreasing in size gradually near the margin (about 16 areolae in $10 \mu$ ). Pseudonodulus absent, one areolae two-thirds between center and margin of the valve situated increased in size. At the corners of the areolae, small dots (characteristic structure of Roperia).

Discussion: This species differs from Roperia tesselata and its varieties in the absence of the distinct pseudonodulus and is similar in the type of areolae and areolae orientation. This species is the ancestor of Roperia tesselata.

Holotype: Plate 21, Figures 13-14 from DSDP Leg 24, 238-13-3. $75 \mathrm{~cm}$, tropical Indian Ocean. Collection Schrader.

Paratype: Plate 14, Figures 3-4. Collection Schrader.

\section{Roperia tesselata (Roper)}

Grunow in Van Heurck (1881)

(Plate 21, Figures 9-12)

Description: Hustedt, 1930, p. 523-524, fig. 297.

Roperia tesselata var. coscinodiscoides (Mann) Kolbe (1955)

Description: Kolbe, 1955, p. 176-177, pl. 1, fig. 6.

Roperia tesselata var. ovata Mann (1925)

Description: Mann, 1925, p. 143, pl. 31, fig. 3.

Genus ROUXIA Brun and Heribaud (1893)

Rouxia moholensis Schrader (1974)

(Plate 20, Figure 12-15)

Description: Schrader, 1973b, p. 555, pl. 5, fig. 11-12. 11-12.

Rouxia naviculoides Schrader (1973a)

Description: Schrader, 1973a, p. 710, pl. 3, fig. 27-30.

Rouxia californica M. Peragallo

in Tèmpère and Peragallo (1910)

(Plate 20, Figure 10)

Description: Hanna, 1930, p. 186-188, pl. 14, fig. 6-7; Schrader, 1973a, p. 710 , pl. 3, fig. 18-20, 26

\section{Genus STEPHANOPYXIS Ehrenberg (1844)}

Stephanopyxis turris (Grey. and Arn.) Ralfs in Pritchard (1861)

Description: Hustedt, 1928 , p. $304=307$, fig. 140 .

Genus SYNEDRA Ehrenberg (1830)

Synedra jouseana Sheshukova-Poretzkaya (1962)

Description: Sheshukova-Poretzkaya, 1967, p. 245; Schrader, 1973a, p. 710, pl. 23, fig. 21-23, 25, 28.

\section{Genus THALASSIONEMA Grunow in Van Heurck (1881)}

Thalassionema lineatum Jousé (1971)

Description: Jousé, 1971p, 15-16, fig. 3 (in Russian).

Thalassionema nitzschioides Grunow in Van Heurck (1881)

Description: Hustedt, 1959 , p. 244-246, fig. 725; Hasle and Mendiola, 1967, p. 111, fig. 5, 27-34, 39-44.

\section{Genus THALASSIOSIRA Cleve (1873) \\ Thalassiosira antarctica Comber (1896) \\ (Plate 3, Figures 10-11)}

Description: Hendey, 1937, p. 237-238; Hustedt, 1958, p. 108-109, pl. 3, fig. 1-3.
Thalassiosira burckliana $\mathrm{n}, \mathrm{sp}$.

Synonyms: Thalassiosira sp. A. Burckle, 1972, p. 241, pl. 1, fig. 1. Thalassiosira nativa Sheshukova-Poretzkaya e.p. in Schrader, 1973a, p. 712, pl. 14, fig. 7

Description: Cells solitary, valves small $9-24 \mu$ in diameter. Valves flat with slightly rounded valve margins. One row of strutted tubuli near the valve margin (compare Plate 1, Figure 23). No labiate process could be observed near the margin with normal light microscopic methods. Numerous very small strutted tubuli are scattered over the center of the valve (5-35), forming a distinct, slightly expressed central region $(1-4 \mu$ in diameter). Areolae hexagonal decreasing in size towards the margin (6-8 in $10 \mu$ in the middle of the valve). Areolae arranged in sectors, medium rows parallel to the outer radial rows.

Discussion: This species resembles Thal. antiqua (Grun.) Cleve but differs in the irregularly bordered central part with fine strutted tubuli. In Thal. antiqua, the central part is clearly defined and exactly bordered by some hexagonal larger aerolae.

Holotype: Plate 1, Figure 22 from DSDP Leg 24, 238-27-2 $125 \mathrm{~cm}$, tropical Indian Ocean. Collection Schrader.

Paratype: Plate 1, Figures 21, 23, 24-25, 26. Collection Schrader.

Thalassiosira convexa Muchina (1965)

(Plate 2, Figures 1-5, 10-13)

Description: Donahue, 1970 , p. 136-137, pl. 3, fig. a-f; Schrader, 1973a, p. 712, pl. 11, fig. 37-38.

Thalassiosira convexa var. aspinosa $\mathrm{n}$. var. (Plate 2, Figures 8-9, 13a-21)

Description: This variety differs from the species by the non-spinous margin; other morphological features are identical with Thal. convexa. This variety seems to be a link in the evolution of the whole Thalassiosira convexa group, starting with Thalassiosira praeconvexa-Thalassiosira pliocenica-Thalassiosira convexa var. aspinosa and Thalassiosira convexa.

Holotype: Plate 2, Figures 13a-15 from DSDP Leg 24, 238-17-3 $75 \mathrm{~cm}$, tropical Indian Ocean. Collection Schrader.

Thalassiosira excentrica (Ehr.) Cleve (1904)

(Plate 11, Figures 7-8, Plate 14, Figures 6-7, 9-10)

Description: Sheshukova-Poretzkaya, 1967, p. 141-142, pl. 14 fig. 4. All individuals with a "Coscinodiscus excentricus structure" and with a single strutted tubulus in the center of the valve have been identified as Thal. excentrica; others without a central strutted tubulus have been identified as Cosc. excentricus.

\section{Thalassiosira gravida Cleve (1896)}

Description: Hustedt, 1930 , p. $325-326$, fig. 161; SheshukovaPoretzkaya 1967, p. 147-148, pl. 15, fig. 1.

\section{Thalassiosira miocenica n. sp.}

Synonym: Thalassiosira usatchevii Jousé in Burckle 1972, p. 228 (no illustration)?

Description: Cells solitary, valves small $16-25 \mu$ in diameter. Valves convex (appr. $7 \mu$ in height). One row of spines near the margin. No labiate process could be observed near the margin with normal light microscope methods. Central area flattened with one to three muceous pores (compare Plate 22, Figure 4). Areolae hexagonal forming a complete meshwork over the entire valve, approximately of the same size all over the valve, 7-8 in $10 \mu$. Areolae arranged in curved rows forming somewhat parallel lines, which are often tangential. Valve margin distinct, approximately $0.5 \mu$ wide; hyaline with one row of hexagonal areolae 8 in $10 \mu$.

Discussion: This species is near to Thal. praeconvexa from which it differs by its tangential rows of areolae and the more convex valves, to Thal. usatchvii from which it differs by the finer areolation and the smaller margin, to Thal. convexa var. aspinosa from which it differs in the coarser areolation and the nonradiate rows.

Holotype: Plate 22, Figure 4 from DSDP Leg 22, Site 213-8-3, 50-51 cm, tropical Indian Ocean. Collection Schrader.

Paratype: Plate 22, Figures 1-3, 5, 11-13. Collection Schrader. 
Thalassiosira nativa Sheshukova-Poretzkaya (1964)

(Plate 1, Figures 1-2, 12, 17-18)

Description: Sheshukova-Poretzkaya, 1967, p. 145, pl. 14, fig. 7.

Thalassiosira oestrupii (Ostenfeld) Proskina-Lavrenco (1956)

(Plate 1, Figures 3-11, 13-16, 19-20; Plate 14, Figure 5)

Description: Hustedt, 1930 , p. 318 , fig. 155 (as Coscinosira oestrupii).

Thalassiosira plicata n. sp.

Description: Cells solitary, valves $20-36 \mu$ in diameter, slightly convex with a tangential plication in the center of the valve, one side being convex, the other being concave. One row of strutted tubuli near the well-defined, finely striated valve margin (appr. 1-2 $\mu$ broad). One labiate process within this marginal row. In between the center of the valve and the valve margin one concentric row of strutted tubuli, which are easily recognized at specific focus. Areolae hexagonal, decreasing in size gradually from the center to the margin (approximately 10 in $10 \mu$ in the center and approximately in $10 \mu$ near the margin). Areolae arranged in radial fascicles and arranged within each fascicle parallel to the longest radial row. Areolae near the margin also arranged to give the appearance that a secondary series of lines are in weak curves or placed tangentially.

Discussion: No similar Thalassiosira species was found in the literature. This species is most characterized by its central plication and the middle row of strutted tubuli.

Holotype: Plate 3, Figures 1-2 from DSDP Leg 24, 238-6-4, 75 $\mathrm{cm}$, tropical Indian Ocean. Collection Schrader.

Paratype: Plate 3, Figures 4-6, 7-9. Collection Schrader.

Thalassiosira symbolophora n. sp.

Description: Cells solitary, valves $26-40 \mu$ in diameter, convex with a flat small margin and a flat small central area. One row of strutted labiate process within this row. A second row of labiate processes is located in the middle of the valve between the margin and the center. These processes do possess a labiate interior part (compare Plate 4, Figure 6) and are thus identified as being labiate. Valve margin (appr. $1 / 2-1 \mu$ broad) hyaline. Areolae hexagonal, decreasing in size gradually towards the margin (appr. 13 in $10 \mu$ in the middle and appr. 17 in $10 \mu$ near the margin). Areolae arranged in the same way as in Coscinodiscus symbolophorus: Aerolae in broad radial sectors within which the middle rows are nearly parallel and tangential rows are concave towards the outside.

Discussion: This species is close to Coscinodiscus stellaris Roper and Coscinodiscus symbolophorus Grunow but differs in the presence of one row of marginal strutted tubuli, one marginal labiate process, and one middle row of labiate processes. No similar species has been found in the literature.

Holotype: Plate 4, Figures 1-2 from DSDP Leg 24, 238-2, CC, tropical Indian Ocean.

Paratype: Plate 4, Figures 4-6, 7-8.

Only those Thalassiosira species which could definitively be determined have been treated taxonomically. All the following forms must be studied by transmission and scanning electronmicroscope and compared with other Thalassiosira species before they can be accurately classified.

Thalassiosira sp.

Thala ssiosira sp. I Schrader

Thalassiosira sp. II Schrader

Thalassiosira sp. III Schrader

Thalassiosira sp. 6 Schrader

Thalassiosira sp. 7 Schrader

\section{Genus THALASSIOTHRIX Cleve and Grunow (1880) \\ Thalassiothrix frauenfeldii (Grun.) Grunow in Cleve and Grunow (1880)}

Description: Hustedt, 1959, p. 247-248, fig. 727; Hasle and Mendiola, 1967, p. 113-114, fig. 9-10, 21, 38, 47-52.

\section{Thalassiothrix longissima Cleve and Grunow (1880)}

Description: Hustedt, 1959, p. 247, fig. 726; Hasle and Mendiola, 1967, p. 114, fig. 35-37, 45, 46, 53.

Thalassiothrix monospina n. sp.

Description: Valves elongated $190 \mu$ long and $2-4 \mu$ wide, linear with dissimilar ends, one of them being slightly pointed with a solitary spine which rises on the valve and is slightly bent, and the other one somewhat widened and bluntly rounded. Marginal punctae approximately $10-11$ in $10 \mu$.

Discussion: This species differs from Thal. longissima and other allied species in the possession of one solitary spine on one end.

Holotype: Plate 19, Figure 8 from DSDP Leg 24, 238-13-3, $75 \mathrm{~cm}$, equatorial Indian Ocean. Collection Schrader.

Paratype: Plate 19, Figures 9-10. Collection Schrader.

\section{Genus TRICERATIUM Ehrenberg (1839) \\ Triceratium cinnamomeum Greville (1863) (Plate 20, Figures 10, 11)}

Description: Van Heurck, 1880, pl. 126, fig. 1; Kolbe, 1954, p. 47, pl. 2, fig. 18.

Triceratium cinnamomeum var. minor Grunow in Van Heurck (1880)

(Plate 19, Figures 11-13; Plate 20, Figures 5-7)

Description: Kolbe, 1954, p. 47, pl. 2, fig. 20; Grunow in Van Heurck, 1880, explanation to pl. 126, fig. 2 .

\section{Triceratium cinnamomeum forma quadrangulata \\ Grunow in Van Heurck (1880)}

(Plate 20, Figure 9)

Description: Grunow in Van Heurck, 1880, explanation to pl. 126, fig. 1; Kolbe, 1954, pl. 2, fig. 19.

\section{Triceratium cinnamomeum forma 1}

This species differs from other Triceratium cinnamomeum species by its broad rounded and protuding edges. Only a few broken specimens were found. Taxonomic position will be clarified at a later date.

\section{Genus TRINACRIA Heiberg (1863)}

All species found occur commonly in the Moler Formation of Denmark (lower Eocene) and are reworked into the nondiatomaceous sequences of Site 238 and 236.

\section{Trinacria excavata Heiberg (1863)}

Description: Hustedt, 1930, p. 887-888, fig. 532; Benda, 1972, pl. 3, fig. 23-24.

\section{Trinacria regina Heiberg (1863)}

Description: Hustedt, 1930 , p. $884-885$, fig. 528 ; Benda, 1972 , pl. 1, fig. 8 .

\section{"EVENTS" FOR ESTABLISHING BIOSTRATIGRAPHIC ZONATION}

"Events" as proposed and defined for radiolarians by Riedel and Sanfilippo (1971) have been also used for diatoms. Morphological characters change continuously with time, and a dominant form in an assemblage is accompanied by a few intraspecific variations which resemble its ancestor and its descendant. Morphotypic ranges are long and do overlap one another depending on the sedimentation rate and/or sampling distance.

In Table 5, I have made distinctions between "evolutionary" and "morphotypic" limits of species and have indicated the two samples between which the event 
TABLE 5

Diatom Events, Sites 213, 215, 238

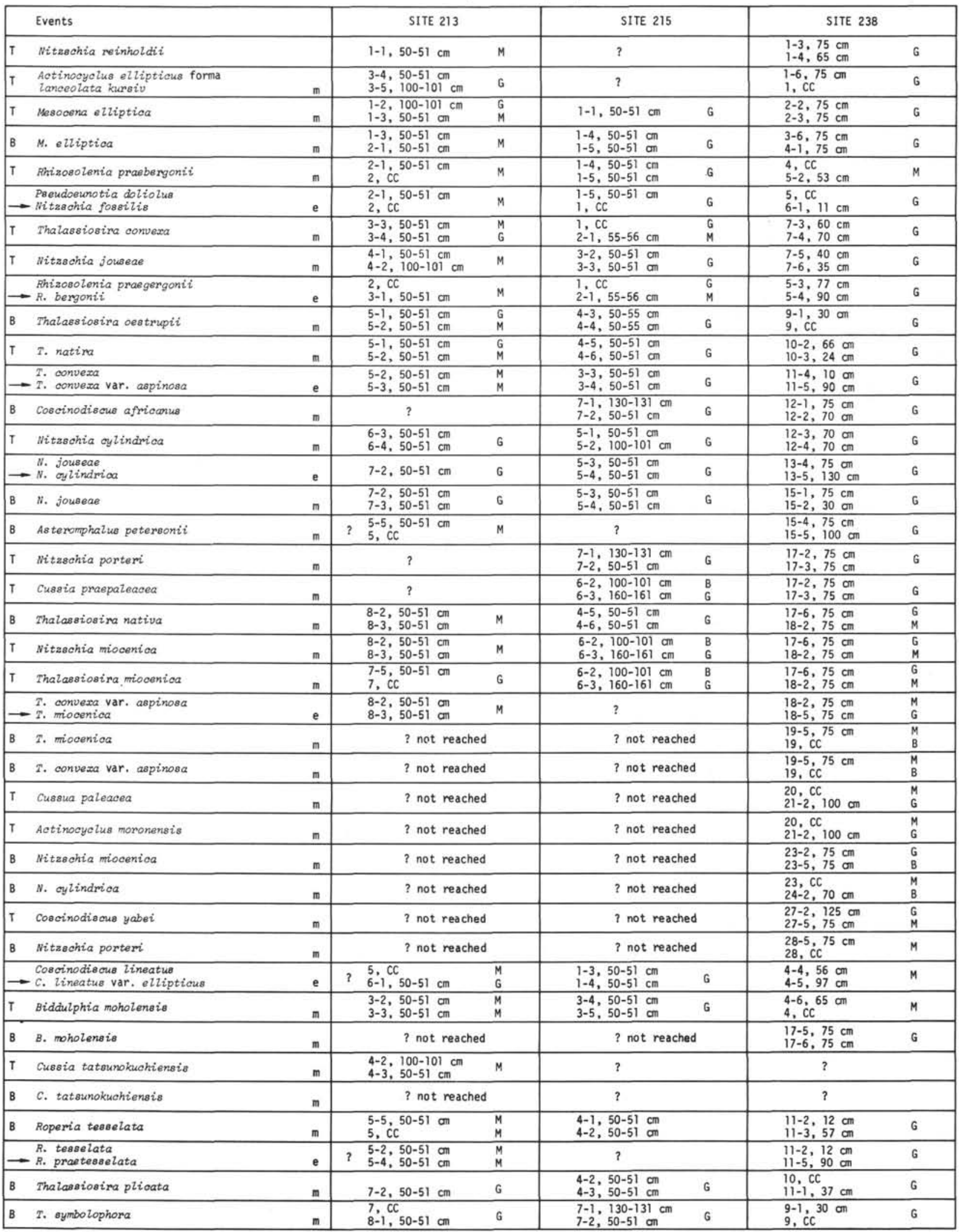

LEGEND: $\underline{I}=$ top of the range of a species; $\underline{B}=$ bottom of the range of a species.

$\underline{m}=$ morphotypic limits of a species $; \underline{e}=$ evolutionary limits of a species.

$\bar{G}=$ good preservation; $\frac{M}{\bar{l}}=$ moderate preservation.
$\bar{?}=$ events have not been defined or are uncertain. 
occurred, the top and the bottom of the range of a species, and the preservation of the diatom assemblage $(\mathrm{M}=$ moderate, $\mathrm{G}=$ good $)$. Events which have not been defined and or which are uncertain have been marked with a question mark.

\section{ETHMODISCUS OOZE INTERPRETATION}

Ethmodiscus ooze has been found at the following levels:

\begin{tabular}{lrc}
\hline \multicolumn{1}{c}{ Site 238} & Site 213 & \multicolumn{1}{c}{ Site 215} \\
\hline $1-6,75 \mathrm{~cm}$ & $1-1,50-51 \mathrm{~cm}$ & $2-1,55-56 \mathrm{~cm}$ \\
$2-2,75 \mathrm{~cm}$ & $1-3,50-51 \mathrm{~cm}$ & \\
$3-1,75 \mathrm{~cm}$ & $2-1,50-51 \mathrm{~cm}$ & \\
$4, \mathrm{CC}$ & $4-1,50-51 \mathrm{~cm}$ & \\
$5-4,90 \mathrm{~cm}$ & $4-4,50-51 \mathrm{~cm}$ & \\
$5, \mathrm{CC}$ & & \\
$6-1,11 \mathrm{~cm}$ & & \\
$7-4,70 \mathrm{~cm}$ & & \\
$7-5,40 \mathrm{~cm}$ & & \\
$10-1,60 \mathrm{~cm}$ & & \\
$10-2,66 \mathrm{~cm}$ & & \\
$10-6,50 \mathrm{~cm}$ & & \\
\hline
\end{tabular}

The Ethmodiscus ooze is defined as a diatomaceous sediment of which 80 percent of the diatom individuals and fragments are Ethmodiscus. An enrichment of Liostephania stages of various diatom species was found to occur within these oozes (Figure 13), whereas in the overlying and underlying sediment samples, only a very few Liostephania individuals were found.

The occurrence and accumulation of Ethmodiscus in deep-sea sediments has been interpreted to reflect high production of Ethmodiscus in the overlying euphotic zone (Wiseman and Hendey, 1953), and represents a biocoenosis characteristic of low dissolved phosphate (Belyaeva, 1970).

Riedel (1954) interpreted the accumulation of Ethmodiscus rex as a result of erosion of older fossil material.

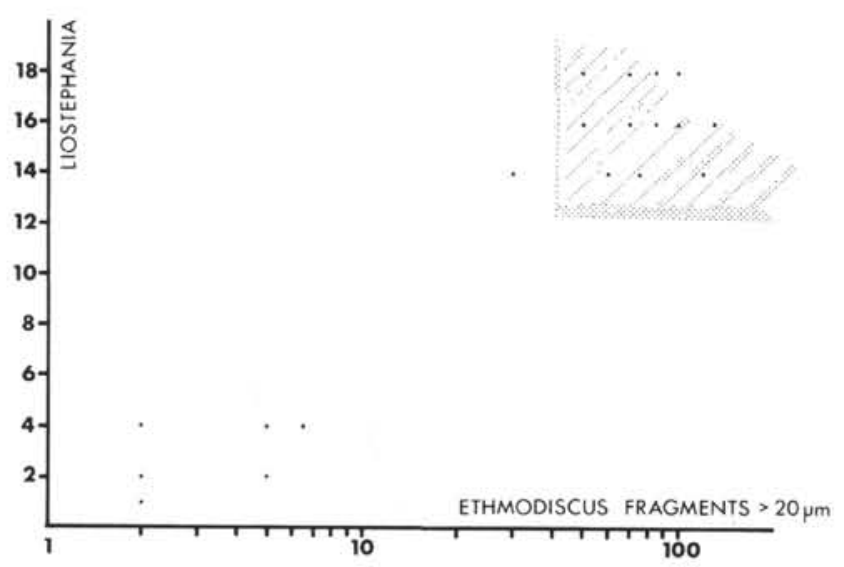

Figure 13. Plot of number of Ethmodiscus fragments coarser $20 \mu$ and number of Liostephania individuals. Dotted area characterizes Ethmodiscus ooze.

Belyaeva (1970) found in plankton counts (Juday net, $180 \mu$ mesh, $0-100 \mathrm{~m}$ water depth) over a traverse in the equatorial Pacific $\left(160^{\circ}\right.$ east longitude and $176^{\circ}, 154^{\circ}$, and $\left.140^{\circ}\right)$, Ethmodiscus rex occurring at about $69.6 \%$ of all investigated stations. Unfortunately no counts are presented, and the occurrence of a species in a sample does not reflect its abundance. Traverse at $140^{\circ}$ east longitude of Belyaeva (1970) corresponds to water sample stations which have been investigated by Hasle (1959). Hasle did not find any Ethmodiscus in water samples of 2-250 ml. The phosphate content of surface water ranged from 0.51 $\mu$-atoms $\mathrm{P} / 1$ to $0.17 \mu \mathrm{g}$-atoms $\mathrm{P} / 1$. The surface phosphate content (in $\mu$ g-atoms P/1) of water overlying DSDP Leg 22 and 24 Sites are (Wyrtke, 1971) as follows:

\begin{tabular}{lcc}
\hline & $\begin{array}{c}\text { Summer } \\
\text { May-October }\end{array}$ & $\begin{array}{c}\text { Winter } \\
\text { November-April }\end{array}$ \\
\hline Site 238 & 0.2 & $>0.2$ \\
Site 213 & 0.2 & 0.2 \\
Site 215 & 0.2 & 0.2 \\
\hline
\end{tabular}

The accumulation of Ethmodiscus in deep-sea sediments can be controlled by the following parameters: (1) High production of Ethmodiscus in the biocoenosis, (2) High settling rates in the water column, (3) Low dissolution rates during settling, and (4) Low dissolution within the sediment and or sediment water interface. These are discussed below.

1) High production of Ethmodiscus in the euphotic zone has not been reported by planktologists (Wood, 1967).

2) Ethmodiscus ranges in size from 100 to $2000 \mu$. Smayda (1970) shows the sinking rate of Ethmodiscus rex (1500-1750 $\mu$ diameter) to be $465-510$ meters per day, and for Ethmodiscus fragments to be 28-864 meters per day. Only 5-12 days (Smayda, 1970) would thus be required by an Ethmodiscus to reach the depth range reported in the Pacific of areas with high Ethmodiscus content in the sediment (4200 m, Wiseman and Hendey, 1953).

3) Dissolution rate of Ethmodiscus will be low due to a short exposure period of the frustrule in the water column. The chemical reactive surface of Ethmodiscus is about ten times lower than a Chaetoceros cell (relatively thick, compact membranes $0.2-0.4 \mu$ in diameter). The polysaccharid cell-wall content may also be important to the low dissolution rate during descent (Hecky et al., 1973).

4) A small surface area and coatings of iron, magnesium and calcium alumino-silicates (Hurd, 1972) are responsible for the low dissolution of Ethmodiscus opal tests within the sediment-water interface and within the sediment.

The accumulation of Ethmodiscus in sediments is caused by the presence of Ethmodiscus individuals in the biocoenosis, by the accelerate sinking rate of these frustules through the water column (where other species of the living assemblage are mostly being dissolved [Berger, 1968; Schrader, 1971]), and by the small reactive surface which prevents tests from being dissolved within the sediment.

Liostephania individuals, representing solution stages of diatom frustules, are enriched within the Ethmodiscus oozes (Figure 13).

The intermittent occurrence of Ethmodiscus ooze within well-diversified siliceous test bearing pelagic sediments at Sites 238, 213, and 215 is related to the sediment 
producing biocoenosis: Low phytoplankton production $=$ enrichment of Ethmodiscus fragments, high phytoplankton production $=$ well-preserved siliceous assemblage .

\section{ACKNOWLEDGMENTS}

This investigation was supported by the U.S. National Science Foundation through the Deep Sea Drilling Project and by the Deutsche Forschungsgemeinschaft. I thank W. R. Riedel (Scripps Institution of Oceanography, La Jolla) and E. Seibold (Geological Institute, Kiel) for help and encouragement during this investigation. E. T. Bunce (Woods Hole Oceanographic Institution) and R. L. Fisher (Scripps Institution of Oceanography, La Jolla) Co-Chief Scientists aboard the Glomar Challenger, Leg 24, made the nanno sample-splits available for this report. L. Musich (DSDP) assisted in technical editorial questions and E. Vincent (University of Southern California, Los Angeles), P. Roth (Scripps Institution of Oceanography), J. Thiede (Geological Institut, Bergen) and D. Bukry (USGS, La Jolla) assisted in paleontological questions. Typing and proofreading was done by my wife, Frau Schmidtmann, and Frau Prokopek.

\section{REFERENCES}

Abdel-Monem, A., Gast, P. W., and Watkins, N. D., 1971. Potassium-argon ages, volcanic stratigraphy, and geomagnetic polarity history of the Canary Islands: Lanzarote, Fuerteventura, Gran Canaria, and La Gomera: Am. J. Sci., v. 271, p. 490-521.

Agardh, C. A., 1824. Systema Algarum: Literis Berlingianis, (Lundae), v. 37, 312 p.

Bailey, J. W., 1854. Notes on new species and localities of microscopical organisms: Smithsonian Contrib. Knowledge, v. 7, p. 1-15.

- 1856. Notice of microscopic forms in the soundings of the Sea of Kamtchatka: Am. J. Sci., v. 22, p. 1-6.

Benda, L., 1972. The diatoms of the Moler Formation of Denmark (lower Eocene). A preliminary report: Nova Hedwigia, Beihefte, v. 39 , p. 251-266.

Berger, W. H., 1968. Radiolarian skeletons: solution with depth: Science, v. 159, p. 1237-1238.

Berggren, W. A., 1969. Cenozoic chronostratigraphy, planktonic foraminiferal zonation and radiometric time scale: Nature, v. 224 , p. $1072-1075$.

, 1972. A Cenozoic time scale-some implications for regional geology and paleobiography: Lethaia, v. 5, p. 195-215.

Berggren, W. H., Philips, J. D., Bertels, A., and Wall, D., 1967. Late Pliocene-Pleistocene stratigraphy in deep-sea cores from the south-central North Atlantic: Nature, v. 216 , p. 253-254.

Belyaeva, T. V., 1970. Taxonomy and distribution pattern of plankton diatoms in the equatorial Pacific: (in Russian with English abstract), Oceanology, v. 10 (1) p. 132-139, Moscow.

Brightwell, T., 1858. Further observations on the genera Triceratium and Chaetoceros: Quat. J. Micros. Sci., v. 6, p. 153-155.

Brun, J. and Heribaud, J., 1893. Les Diatomées d'Auvergne: Libr. Sci. Nat. Paris, 233 p.
Brun, J. and Tempére, J., 1889. Diatomées Fossiles du Japon. Espèces Marines \& Nouvelles des Calcaires Argileux des Sendai \& de Yedo: Soc. Phys. d'Hist. Nat. Genève Mem. v. 30 (9), 75 p.

Bukry, D. and Foster, J. H., 1973. Silicoflagellate and diatom stratigraphy, Leg 16, Deep Sea Drilling Project. In Van Andel, T. H.; Heath, G. R., et al., Initial Reports of the Deep Sea Drilling Project, Volume XVI: Washington (U.S. Government Printing Office), p. 815-871.

Burckle, L. H., 1969. Late Cenozoic planktonic diatom zones in equatorial Pacific sediments (abstr.): Geol. Soc. Am. Abs. 1969, pt. 7, p. 24.

, 1972. Late Cenozoic planktonic diatom zones from the eastern equatorial Pacific: Nova Hedwigia, Beihft., v. 39, p. 217-246.

Castracane, Conte A.F.A., 1875. Contribuzione alla florula delle Diatomee del Mediterraneo ossia esame del contenuto dello stomaco di una Salpa pinnata, pescata a Messina: Atti. Acad. Pontif dei nouvi Lincei., v. 28, p. 377-396.

1886. Report on the scientific results of the voyage of H.M.S. Challenger during the years 1873-1876: Botany, v. 2, 178 p.

Cleve, P. T., 1873. Examination of diatoms found on the surface of the Sea of Japan: Bihang Svensk. Vetensk. Akad. Handl., v. 11(2), p. 1-13.

1883. Diatoms collected during the expedition of the Vega: Ur Vega-Exped. Vetensk. Iakttag., v. 3, p. 457-517.

1896. Diatoms from Buffin Bay and Davis Strait: Bihang Kgl. Svensk. Vetensk. Akad. Handl., Abt. 3, v. 22, $22 \mathrm{p}$.

1904. Plankton table for the North Sea: Bull. Cons. Explor. Mer. 1903-1904, p. 216.

Cleve, P. T. and Grunow, A., 1880. Beiträge zur Kenntnis der arktischen Diatomeen: Kgl. Svensk. Vetensk. Akad. Handl., v. 17(2), p. 3-122, Stockholm.

Comber, T., 1896. On the occurrence of endocysts in the genus Thalassiosira: Microsc. Soc. London Trans., p. 489-491.

Cox, A., 1969. Geomagnetic reversals: Science, v. 163, p. 237-245.

Donahue, J. G., 1970. Pleistocene diatoms as climatic indicators in North Pacific sediments: Geol. Soc. Am. Mem., v. 126, p. 121-138.

Ehrenberg, C. G., 1830 (1832). Beiträge zur Kenntnis der Organisation der Infusorien und ihrer geographischen Verbreitung besonders in Sibirien: Abh. Kgl. Akad. Wiss. Berlin, p. 1-88.

, 1837. Die fossilen Infusorien und die lebendige Dammerde: Preuss. Physik. Abh. Kgl. Akad. Wiss. Berlin. 1838. Die Infusionsthierchen als vollkommene Organismen. Ein Blick in das tiefere organische Leben der Natur: Leipzig (Leopold Voss) 1-7, 1-548. 1839 (1841). Über noch jetzt zahlreich lebende Tierarten der Kreidebildung und den Organismus der Polythalamien: Abh. Kgl. Akad. Wiss. Berlin, p. 81-174. , 1844. Resultate Untersuchungen der ihm von der Südpolreise des Kapt. Rofs in den Jahren 1841-1843: Ber. Berl. Akad. Wiss., p. 182-207 (ref. ex Hendey 1937).

- 1844 (1845). Über zwei neue Lager von Gebirgsmassen aus Infusorien als Meeresabsatz in Nord-Amerika und ein Vergleich derselben mit den organischen Kreidegebilden in Europa und Afrika: Abh. Kgl. Akad. Wiss. Berlin, p. 57-97. 
1845. Vorläufige zweite Mitteilung über die Beziehungen des kleinsten organischen Lebens $\mathrm{zu}$ den vulkanischen Massen der Erde: Ber. Akad. Wiss. Berlin, p. 133-157.

Frenguelli, J., 1949. Diatomeas fósiles de los yacimientos chilenos de Tiltil y Mejiliones: Darwiniana, v. 9(1), p. 97-156.

Gerloff, J., 1970. Elektronenmikroskopische Untersuchungen an Diatomeenschalen VII: Der Bau der Schale von Planktoniella sol (Wallich) Schütt: Nova Hedwigia Beihft. v. 31, Diatomaceae II, Friedr. HustedtGedenkband, p. 203-234, Lehre.

Gran, H. H., 1904. Die Diatomeen der arktischen Meere.-I. Die Diatomeen des Planktons in "Fauna Arctica", auf Grund der Erg. der deutschen Expedition in das Nördl. Eismeer im Jahre 1898: v. 4, p. 511-554, Jena.

Gray, S. F., 1821. A natural arrangement of British plants according to their relations to each other as pointed out by Jussieu, De Candolle, Brown, etc., including those cultivated for use; with an introduction to botany, in which the terms newly introduced are explained: (2 vol., 824 p. and 757 p.) London, (Baldwin, Cradock and Joy).

Greville, R. K., 1859. Descriptions of diatomaceae observed in Californian guano: Quat. J. Microsc. Sci. v. 7, p. $155-166$

, 1860. A monograph of the genus Asterolampra, including Asteromphalus and Spatangidium: Microsc. Soc. London Trans., v. 8 (n.s.), p. 102-124.

, 1862. On the Asterolamprae of the Barbados deposit: Microsc. Soc. London Trans., v. 10 (n.s.) p. 41-55.

1863. Descriptions of new and rare diatoms: Microsc. Soc. London Trans., v. 3 (n.s.), p. 227-237.

Grunow, A., 1867. Diatomeen auf Sargassum von Honduras, gesammelt von Lindig: Hedwigia, v. 6 (1-3), p. 1-8, 17-37.

1868. Algae. In Reise der österreichschen Fregatte Novara um die Erde in den Jahren 1857, 1858, 1859; Bot. pt. 1, 104 p.

1884. Die Diatomeen von Franz-Josefs-Land: Denkschr. Math. naturw. Classe kaiserlichen Akad. Wiss., v. 48 , p. 53-112.

Hajos, M., 1968. Die Diatomeen der miozänen Ablagerungen des Mátravorlandes: Geol. Hungarica, Scr. Paleont., v. 37, p. 33-401.

Hanna, G. D., 1930. A review of the genus Rouxia: J. Paleont. v. 2(4), p. 179-188.

1932. The diatoms of Sharktooth Hill, Kern County, California: Calif. Acad. Sci. Proc. (4th ser.), v. 20 (6), p. 161-263.

Hanna, G. D. and Brigger, A. L., 1970. Observations on Liostephania: Nova Hedwigia, Beihft., v. 31, p. 89-100.

Hanna, G. D. and Grant, W. M., 1926. Expedition to the Revillagigedo Islands, Mexico, in 1925; II Miocene marine diatoms from Maria Madre Island, Mexico: Calif. Acad. Sci. Proc. (4th ser.), v. 15, p. 115-193.

Hasle, G. R., 1959. A quantitative study of phytoplankton from the equatorial Pacific: Deep-Sea Res., v. 6 (1), p. 38-59.

1972. The distribution of Nitzschia seriata Cleve and allied species: Nova Hedwigia, Beihft. v. 39, p. 171-190.

Hasle, G. R. and Mendiola, de B. R. E., 1967. The fine structure of some Thalassionema and Thalassiothrix species: Phycologia v. $6,(2+3)$, p. $107-125$.
Hassal, A. H., (1844) 1845. A history of the British freshwater algae (including description of Diatomaceae and Desmidiaceae): v. 1, 462 p., v. 2. London (Taylor, Walton and Maberly).

Hays, J. D., Saito, T., Opdyke, N. D., and Burckle, L. H., 1969. Pliocene-Pleistocene sediments of the equatorial Pacific: Their paleomagnetic, biostratigraphic and climatic record: Geol. Soc. Am. Bull., v. 80, p. 1481-1514.

Hecky, R. E., Mopper, K., Kilham, P., and Degens, E. T., 1973. The amino acid and sugar composition of diatom cell walls: Marine Biol., v. 19, p. 323-331.

Heiberg, P. A. C., 1863. Conspectus criticus Diatomacearum Danicarum: (Wilhelm Priors Forlag), $135 \mathrm{p}$. Kjobenharn.

Heiden, H. and Kolbe, R. W., 1927. Die marinen Diatomeen der deutschen Südpolar-Expedition, 1901-1903. In Drygalski, E. (Ed.), Deutsche Südpolar Expedition 1901-1903, Berlin und Leipzig (Walter de Gruyter \& Co.) v. 8 (Botanik), no. 5, p. 447-715.

Hendey, N. J., 1937. The plankton diatoms of the southern seas: Discovery Repts., v. 16, p. 151-364.

1964. An introductory account of the smaller algae of British coastal waters. Part V: Bacillariophyceae (Diatoms): London (Her Majesty's Stationery Office), $317 \mathrm{p}$.

Hendey, N. J. and Wiseman, D. H., 1953. The significance and diatom content of a deep-sea floor sample from the neighbourhood of the greatest oceanic depth: Deep Sea Res., London (Pergamon Press), v.1, p. 42-59.

Hurd, D. C., 1972. Interaction of biogenic opal, sediment and seawater in the central equatorial Pacific: Hawaii Inst. Geophys., HIG-72-22, 81 p., Hawaii.

Hustedt, FR., 1924. Die Bacillariaceen-Vegetation des Sarekgebirges: Naturwiss. Untersuchungen des Sarekgebirges in Schwedisch-Lappland, v. 3, Bot. 6, p. 525-627, Stockholm.

1928-1929. Die Kieselalgen Deutschlands, Osterreichs und der Schweiz. In L. Rabenhorst KryptogamenFlora von Deutschland, Österreich und der Schweiz: v. 7, pt. 1, Liefg. 1-3, p. 1-608.

1930. Die Kieselalgen Deutschlands, Osterreichs und der Schweiz. In L. Rabenhorst; Kryptogamen-Flora von Deutschland, Österreich und der Schweiz; v. 7, pt. 1, 920 p., Leipzig.

1958. Diatomeen aus der Antarktis und dem Südatlantik: Deutsche Antarkt. Exped. 1938/1939, Wiss. Exped., v. 2, p. 103-191, Hamburg.

1959. Die Kieselalgen Deutschlands, Osterreichs und der Schweiz. In L. Rabenhorst, Kryptogamen-Flora von Deutschland, Österreich u. d. Schweiz: Leipzig, (Akad. Verlagsges.), v. 7, pt. 2,9+845 p.

Jousé, A. P., 1971. Species formaeque novae et curiosae Bacillariophytorum in sedimentis fundi Oceani Pacifici: Novitates Systematicae Plantarum non Vascularium, Acad. Sci. URSS, Leningrad, v. 8.

1971b. Diatoms in Pleistocene sediments from the northern Pacific Ocean. In Funnell, B.M. and Riedel, W. R. (Eds.) Micropaleontology of the Oceans: Cambridge (Cambridge University Press), p. 407-421.

Kanaya, T., 1957. Eocene diatom assemblages from the Kellogg and "Sidney" Shales, Mt. Diablo Area, California: Sci. Repts. Tohoku Univ., 2nd ser. v. 28, 124 p., Sendai.

1959. Miocene diatom assemblages from the Onnagawa Formation and their distribution in the 
correlative formations in northeast Japan: Sci. Repts. Tohoku Univ. 2nd ser. (Geol.), v. 30, p. 1-130, Sendai. 1969. Diatom micropaleontology and deep-sea stratigraphy of the North Pacific: La Mer, (Bull. Soc. Franco-Japonaise d'oceanogr.), v. 7, p. 183-196. 1971. Some aspects of pre-Quaternary diatoms in the Oceans. In Funnell, B.M., and Riedel, W. R. (Eds.), The micropaleontology of the oceans. Cambridge (Cambridge Univ. Press), p. 545-565.

Kanaya, T. and Koizumi, J., 1970. The progress in the younger Cenozoic diatom biostratigraphy in the northern Circum-Pacific region (In Japanese): J. Mar. Geol., v. 6, p. 47-66.

Karsten, G., 1907. Das indische Phytoplankton nach dem Material der Deutschen Tiefsee-Expedition 1898-1899: Wiss. Ergbn. Deutsche Tiefsee-Expd. auf dem Dampfer Valdivia 1898-1899, Carl Chun (Ed.), v. 2, pt. 2, p. 221-548

Kisselev, J. A., 1931. Das Phytoplankton und seine Verteilung im Liman von Amur (in Russian with German summary): Issled morej SSSR, v. 14, p. 31-116.

Kobayashi, K., Kitazawa, K., Kanaya, T., and Sakai, T., 1971. Magnetic and micropaleontological study of deep-sea sediments from the west central equatorial Pacific: Deep-Sea Res. v. 18, (11), p. 1045-1062.

Koizumi, J., 1968. Tertiary diatom flora of Oga Peninsula, Akita Prefecture, northeast Japan: Sci. Rept. Tohoku Univ., 2nd ser. (Geol.), v. 40(3), p. 171-225.

1972. Marine diatom flora of the Pliocene Tatsunokuchi Formation in Fukushima Prefecture: Paleont. Soc. Japan, Trans. Proc. (n.s. m), v. 86, p. 340-359.

, 1973. The late Cenozoic diatoms of Sites 183-193, Leg 19, Deep Sea Drilling Project. In Creager, J. S., Scholl, D. W., et al., Initial Reports of the Deep Sea Drilling Project, Volume XIX; Washington (U. S. Government Printing Office), p. 805-856.

Kolbe, R. W., 1954. Diatoms from equatorial Pacific cores: Rept. Swedish Deep-Sea Exped. v. 6, pt. 2, 49 p., Göteborg.

- 1955. Diatoms from equatorial Atlantic cores: Rept. Swedish Deep-Sea Exped. v. 7, pt. 3, p. 149-184, Göteborg.

- 1957. Diatoms from equatorial Indian Ocean cores. Reports of the Swedish Deep-Sea Exped. Pettersson (Ed.), Sediment Cores from the Indian Ocean, v. 9, pt. 1, p. 3-50, Göteborg.

Krey, J., 1971. Primary production in the Indian Ocean I. The Biology of the Indian Ocean, Symposium, Abstracts.

Kützing, F. T., 1834 (1833). Synopsis Diatomacearum oder Versuch einer systematischen Zusammenstellung der Diatomeen: Linnaea, v. 8, p. 529-620, Berlin.

, 1844. Die kieselschaligen Bacillarien oder Diatomeen. 152 p. Nordhausen.

Mann, A., 1925. Marine diatoms of the Philippine Islands: Contrib. Biol. Philippine Archipelago and Adjacent Regions, Smithsonian Inst. U. S. Natl. Mus. Bull. 100, v. 4(1), $182 \mathrm{p}$., Washington.

Mayer-Eymar, C., 1868. Tableau synchronistique des terrains Tertiaires superiours. Zürich.

Muchina, V. V., 1963. Biostratigraphic analysis of bottom sediments from station 3802 in the equatorial zone of the Pacific Ocean [in Russian]. Okeanologiya, v. 3, p. 861-869.

, 1965. New species of diatoms from the bottom sediments of the equatorial region of the Pacific [in
Russian with systematic description of species in Latin]: Nov. System. Plant. non Vascularium, Bot. Inst. Akad. Nauk SSSR, p. 22-25.

1969. Biostratigraphy of sediments and some questions of paleogeography of the tropical region of the Pacific and Indian oceans. In Jousé, A. P., Micropaleontology and Organogenous Sedimentation in the Ocean: p. 52-84, Moscow.

Opdyke, N. D., 1972. Paleomagnetism of deep-sea cores: Rev. Geoph. Space Phys., v. 10, p. 213-249.

Pantocsek, J., 1886-1903. Beiträge zur Kenntnis der fossilen Bacillarien Ungarns: Zweite verbesserte Auflage, 3 pts. Berlin, W. Junk, 1903. pt. 1, 77 p., 30 Taf.; pt. 2, 123 p., 30 Taf.; pt. 3, 42 Taf.

Peragallo, H., 1892. Monographie du genre Rizosolenia: Le Diatomiste, v. 1, p. 99-117.

Proskina-Lavrenko, 1956. For reference see Hasle, G. R., 1960. Phytoplankton and ciliate species from the tropical Pacific: Skrift. det Norske Vidensk. Akad., Oslo, Math. Naturv. Kl., no. 2, p. 1-50.

Ralfs, J., 1861. In Pritchard, A. A history of infusoria, living and fossil (Edition 4) London. (Whittaker \& Co.) $968 \mathrm{p}$.

Rattray, J., 1890. A revision of the genus Actinocyclus Ehr: Queckett Microsc. Club. J., v. 4, ser. 2, p. 137-212. 1890. A revision of the genus Coscinodiscus Ehr. and some allied genera: Roy. Soc. Edinburgh, Proc., v. 16 , p. 449-692.

Reinhold, T., 1937. Fossil diatoms of the Neogene of Java and their zonal distribution: Verhande. Geol. Mijnbou. Genootschap. voor Nederland en Kolonien, Geol. ser. pt. 12, p. 43-133.

Riedel, W. R., 1954. The age of the sediment collected at Challenger (1875), Station 225 and the distribution of Ethmodiscus rex (Rattray): Deep-Sea Res., v. 1, p. 170-175.

Riedel, W. R. and Sanfilippo, A., 1971. Cenozoic Radiolaria from the western tropical Pacific. Deep Sea Drilling Project, Leg VII. In Winterer, E. L., Riedel, W. R., et al., Initial Reports of the Deep Sea Drilling Project, Volume VII: Washington (U. S. Government Printing Office), p. 1529-1672.

Saito, T., 1969. Late Cenozoic stage boundaries in deep-sea sediments: Geol. Soc. Am. Abs. 1969, pt. 7, p. 289-290.

Schmidt. A., et al., 1874. Atlas der Diatomaceenkunde. Leipzig (R. Reisland).

Schrader, H.-J., 1969. Die pennaten Diatomeen aus dem Obereozän von Oamaru, Neuseeland: Nova Hedwigia, Beiheft., v. 28, p. 1-124.

1971. Fecal pellets: Role in sedimentation of pelagic diatoms: Science, v. 174, p. 55-57.

, 1973a. Cenozoic diatoms from the northeast Pacific, Leg 18. In Kulm, L. D., von Huene, R., et al., Initial Reports of the Deep Sea Drilling Project, Volume XVIII: Washington (U.S. Government Printing Office), p. $673-797$

1973b. Stratigraphic distribution of marine Denticula species in neogene North Pacific sediments: Micropaleontology, v. 19, p. 417-430.

1974. Revised diatom stratigraphy of the Experimental Mohole Drilling, Guadalupe Site: Calif. Acad. Sci. Proc. 4th ser., v. 39, p. 517-562.

in press. Proposal for a standardized method of cleaning diatom-bearing deep-sea and land-exposed marine sediments; Nova Hedwigia, Beih. 45, Lehre.

Schütt, F., 1893. Das Pflanzenleben der Hochsee: Kiel und Leipzig. 
Shadbolt, G., 1853. A short description of some new forms of Diatomaceae from Port Natal: Micros. Soc. London Trans., v. 2 (n.s.), p. 13-18.

Sheshukova-Poretzkaya, V. S., 1962. Novie i redkie Bacillariophyta iz diatomovoi sviti sakhalina: Uchenic Zapiski lgu, ser., biolog. Nauk, Leningrad Univ., v. 49 (313), p. 203-211.

1964. New and rare marine diatoms of the neogene of Sakhalin and Kamtschatica [in Russian]: Nov. Syst. Plant. non Vascularium, Bot. Inst., Akad. Nauk SSSR, p. 69-77.

1967. Neogene marine diatoms of Sakhalin and Kamtchatica [in Russian with English summary]: Lenningrad (Leningrad Unit.), 327 p.

Simonsen, R. and Kanaya, T., 1961. Notes on the marine species of the diatom genus Denticula Kütz: Int. Revue ges. Hydrobiol., v. 46 (4), p. 498-513.

Smayda, T. J., 1970. The suspension and sinking of phytoplankton in the sea: Oceanogr. Mar. Biol., v. 8, p. 353-414.

Smith, Wm., 1852. Notes on the diatomaceae with descriptions of British species included in the genus Pleurosigma: Ann. Mag. Nat. Hist., v. 9, ser. 2, London. 1853,1856 . Synopsis of British Diatomaceae: London, (John van Voorst), v. 1, 89 p., v. 2, 107 p.

Stradner, H. and Papp, A., 1961. Tertiäre Discoasteriden aus Osterreich und deren stratigraphische Bedeutung: Jb. Geol. B. A., Sonderband 7, p. 1-160.

Tèmpère, J., 1890. Diatomées rares ou nouvelles. Brunia japonica, n.g. et n. sp. Temp: Le Diatomist, v. 1, p. 21-22.
Tèmpère, J. and Peragallo, H., 1907-1915. Diatomées du Monde Entier: Ed. 2, 30 pts. Arcachon.

Van Heurck, H., 1880-1885. Synopsis de diatomées de Belgique: Atlas, Anvers (Ducaju \& Cie). plates 1-132.

Van Landingham, S. L., 1967. Catalogue of the fossil and recent genera and species of diatoms and their synonyms: Pt 1, 493 p., Lehre.

Wallich, G. C., 1860. On the siliceous organisms found in the digestive cavities of the Salpae, and their relation to the Flint nodules of the Chalk Formation: Microsc. Soc. London Trans., v. 8 (n.s.), 36 p.

Wood, E. J. F., 1967. Microbiology of oceans and estuaries: Elsevier Oceanogr. ser., v. 3, p. 1-319.

Wyrtki, K., 1971. Oceanographic atlas of the International Indian Ocean Expedition: XI + 531 p., U. S. Government Printing Office, Washington.

\section{ADDITIONAL SELECTED REFERENCES}

Berger, W. H., and Rad, U. von, 1972. Cretaceous and Cenozoic sediments from the Atlantic Ocean. In Hayes, D. E., Pimm, A. C., et al., Initial Reports of the Deep Sea Drilling Project, Volume XIV: Washington (U. S. Government Printing Office), p. 787-954.

Blow, W. H., 1969. Late middle Eocene to Recent planktonic foraminiferal biostratigraphy: Internat. Conf. Plankt. Microfossils, 1st, Leiden, Proc., v. 1, p. 199-422.

Ricard, M., 1970. Observations sur les diatomées marines du genre Ethmodiscus Castr: Rev. Algologique, v. 1, p. 56-73. 


\section{PLATE 1}

(Magnification 1500X)

Figures 1,2 Thalassiosira nativa Sheshukova sensu Burckle; DSDP $238-11-6,70 \mathrm{~cm}$.

Figures 3-11 Thalassiosira oestrupii (Ostf.) Proskina-Lavrenko

3. DSDP $238-2-2,75 \mathrm{~cm}$.

4,5 DSDP $238-2-2,75 \mathrm{~cm}$.

6-8. DSDP $238-6-4,75 \mathrm{~cm}$.

9. DSDP $238-7-5,40 \mathrm{~cm}$.

10. DSDP $238-7-5,40 \mathrm{~cm}$.

11. DSDP $238-2-2,75 \mathrm{~cm}$.

Figure 12 Thalassiosira nativa Sheshukova sensu Burckle; DSDP $238-11-4,10 \mathrm{~cm}$.

Figures 13-16 Thalassiosira oestrupii (Ostf.) Proskina-Lavrenko

13. DSDP $238-3-1,75 \mathrm{~cm}$.

14. DSDP $238-2-2,75 \mathrm{~cm}$ (girdle).

15,16 . DSDP $238-1-2,75 \mathrm{~cm}$.

Figures 17, 18 Thalassiosira nativa Sheshukova sensu Burckle; DSDP $238-13-4,75 \mathrm{~cm}$.

Figures 19, 20 Thalassiosira oestrupii (Ostf.) Proskina-Lavrenko; DSDP $238-7-5,40 \mathrm{~cm}$.

Figures 21-26 Thalassiosira burckliana n. sp.; DSDP 238-27-2, $125 \mathrm{~cm}$. 
PLATE 1
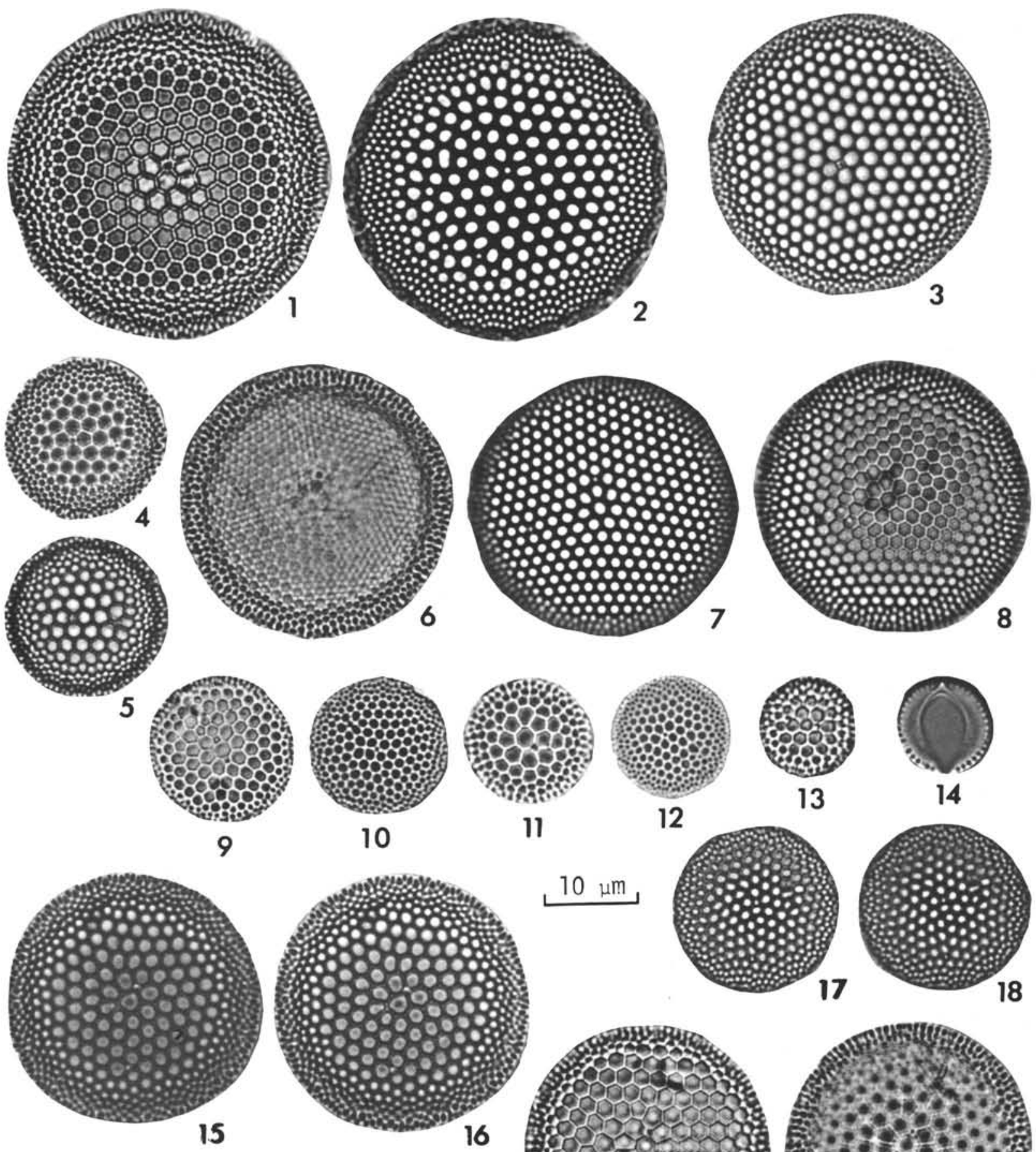

15
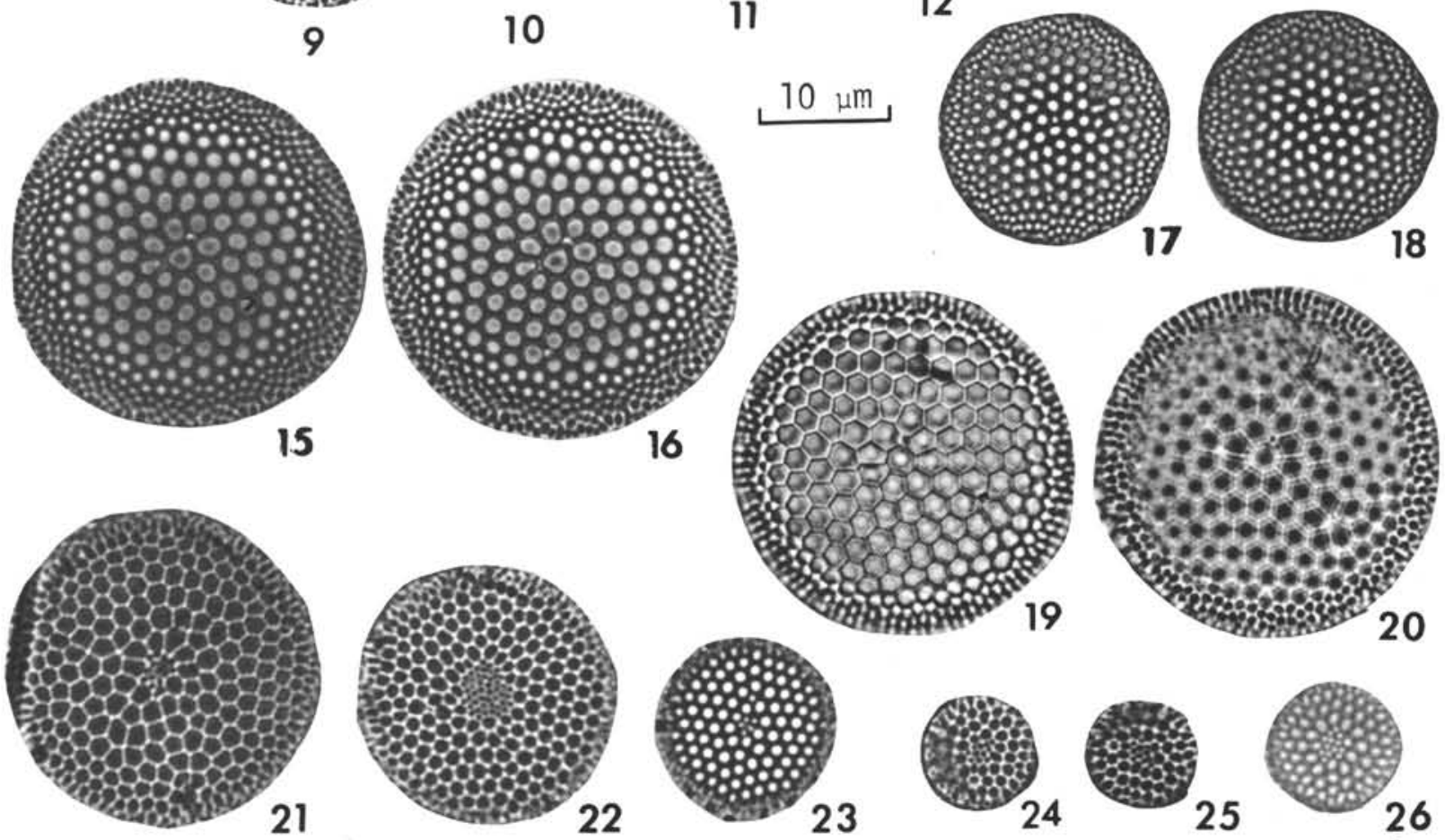


\section{PLATE 2}

(Magnification 1500X)

Figures 1-5 Thalassiosira convexa Muchina

1-3. DSDP $238-7-4,70 \mathrm{~cm}$.

4,5 . DSDP $238-7-4,70 \mathrm{~cm}$.

Figures 6,7 Thalassiosira praeconvexa Burckle; DSDP 238-19-2, $75 \mathrm{~cm}$.

Figures 8,9 Thalassiosira convexa var. aspinosa n. var.; DSDP 238-20-2, $100 \mathrm{~cm}$.

Figures 10-13 Thalassiosira convexa Muchina; DSDP 238-7-5, $40 \mathrm{~cm}$.

Figures 13a-21 Thalassiosira convexa var. aspinosa $\mathrm{n}$. var.

13a-15. DSDP 238-17-3, $75 \mathrm{~cm}$ (type).

16-18. DSDP 238-17-3, $75 \mathrm{~cm}$.

19-21. DSDP $238-17-3,75 \mathrm{~cm}$. 
PLATE 2
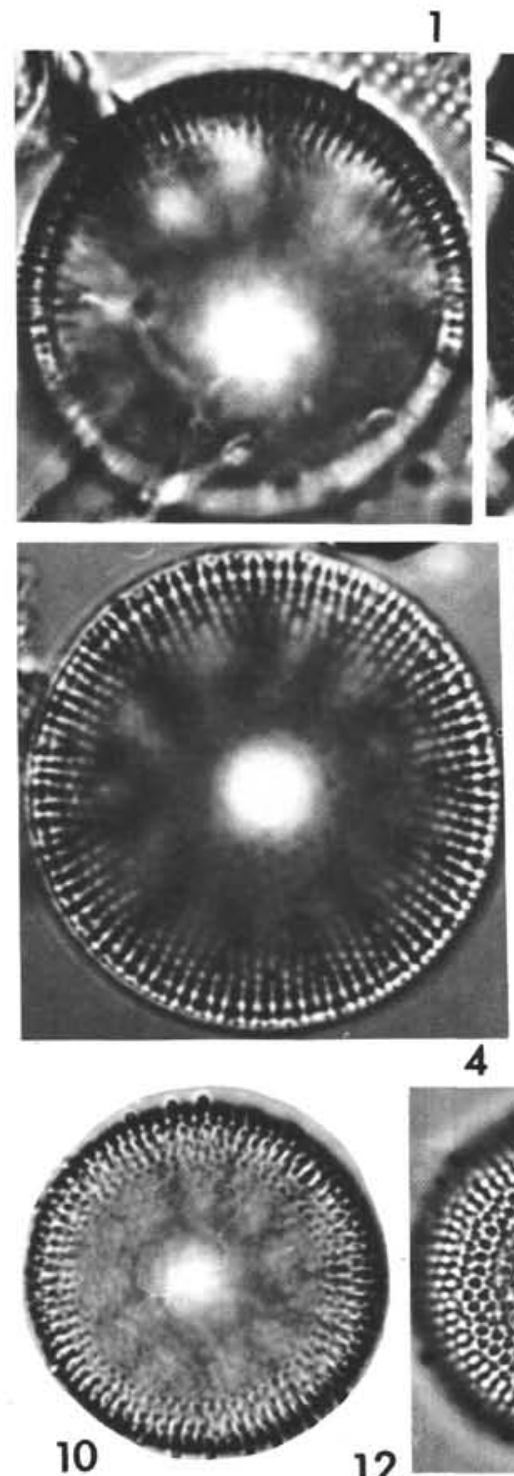

12
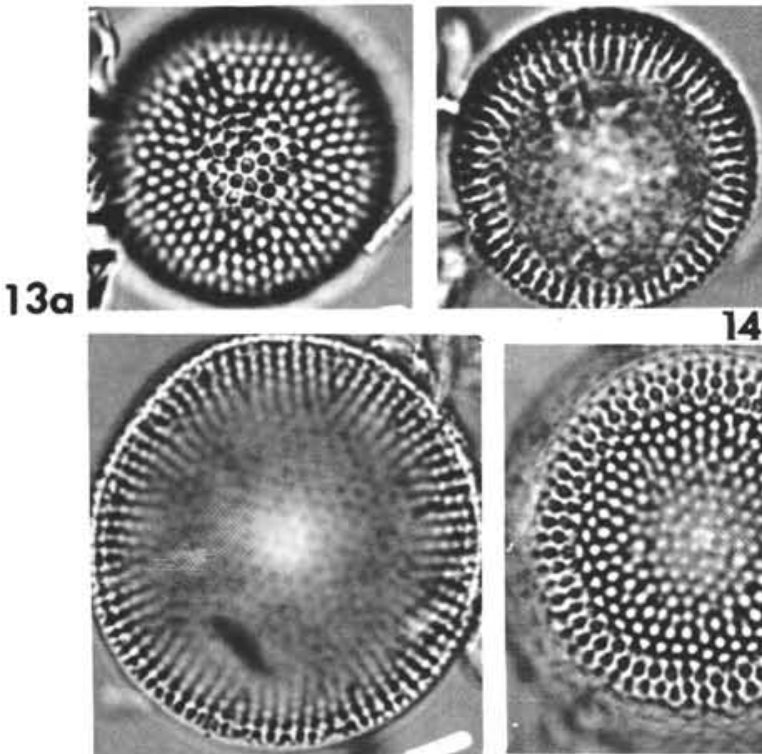

16
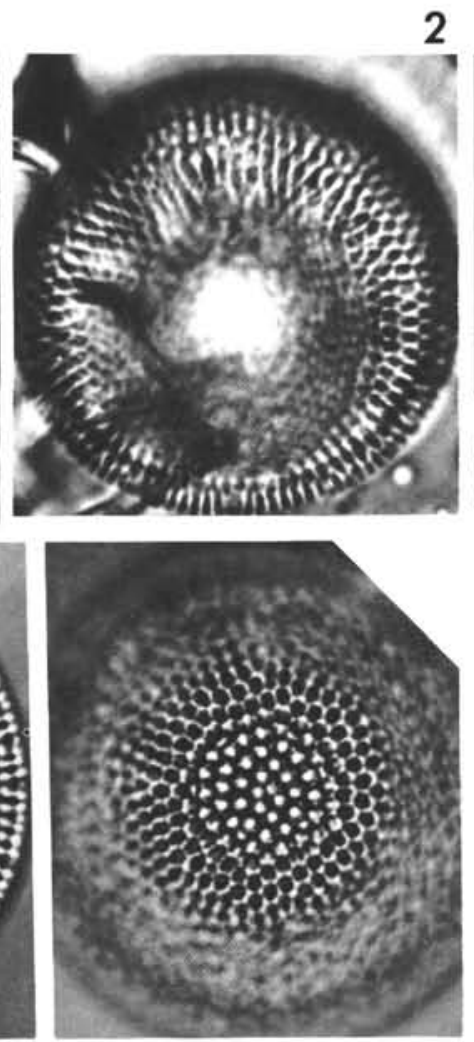

5
2

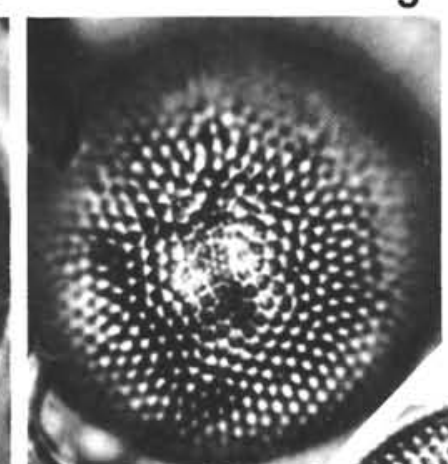

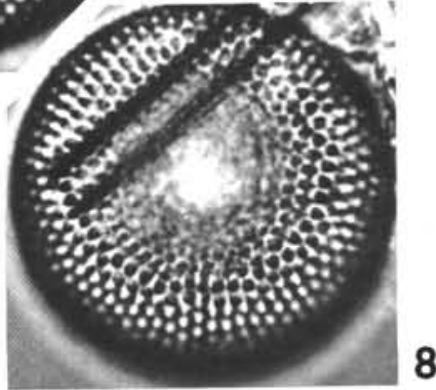

8
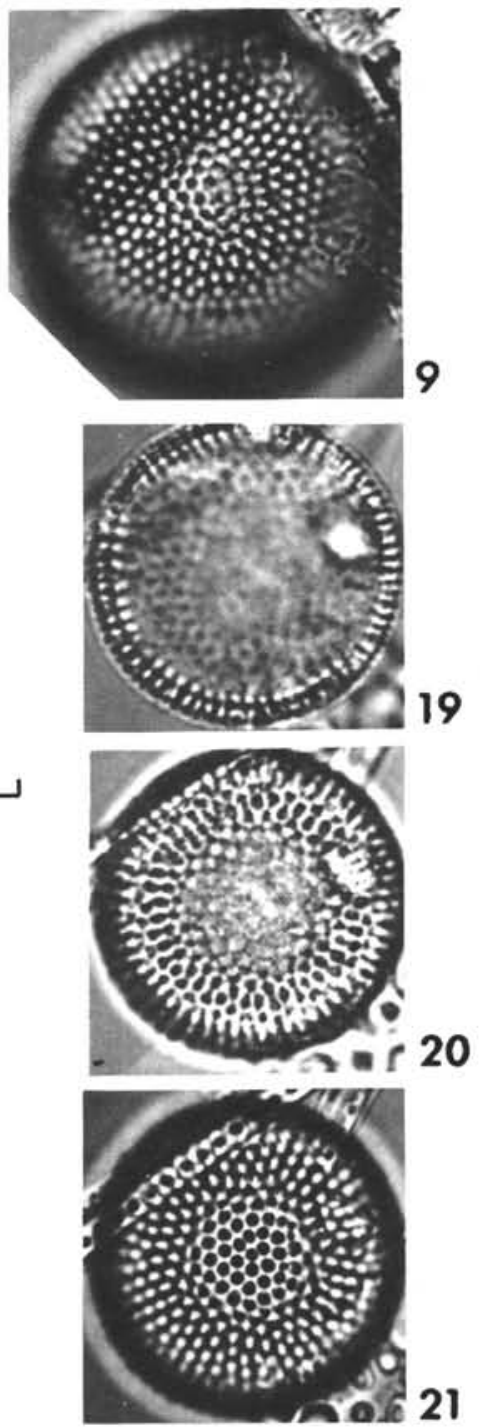

18 


\section{PLATE 3}

(Magnification 1500X)

Figures 1,2 Thalassiosira plicata n. sp. (type); DSDP 238-6-4, $75 \mathrm{~cm}$.

Figure 3 Actinocyclus cf. curvatulus Janisch, with plicate central area. DSDP 238-6-3, $75 \mathrm{~cm}$.

Figures 4-6 Thalassiosira plicata $\mathrm{n}$. sp. with slightly plicate central area; DSDP $238-3-2,75 \mathrm{~cm}$.

Figures 7-9 Thalassiosira plicata $\mathrm{n}$. $\mathrm{sp}$. with plicate and hyaline central area; DSDP $238-7-4,70 \mathrm{~cm}$.

Figures 10,11 Thalassiosira antarctica Comber; DSDP 238-10-1, $60 \mathrm{~cm}$.

Figures 12,13 Thalassiosira antarctica Comber; DSDP 238-11-6, $70 \mathrm{~cm}$. 
PLATE 3
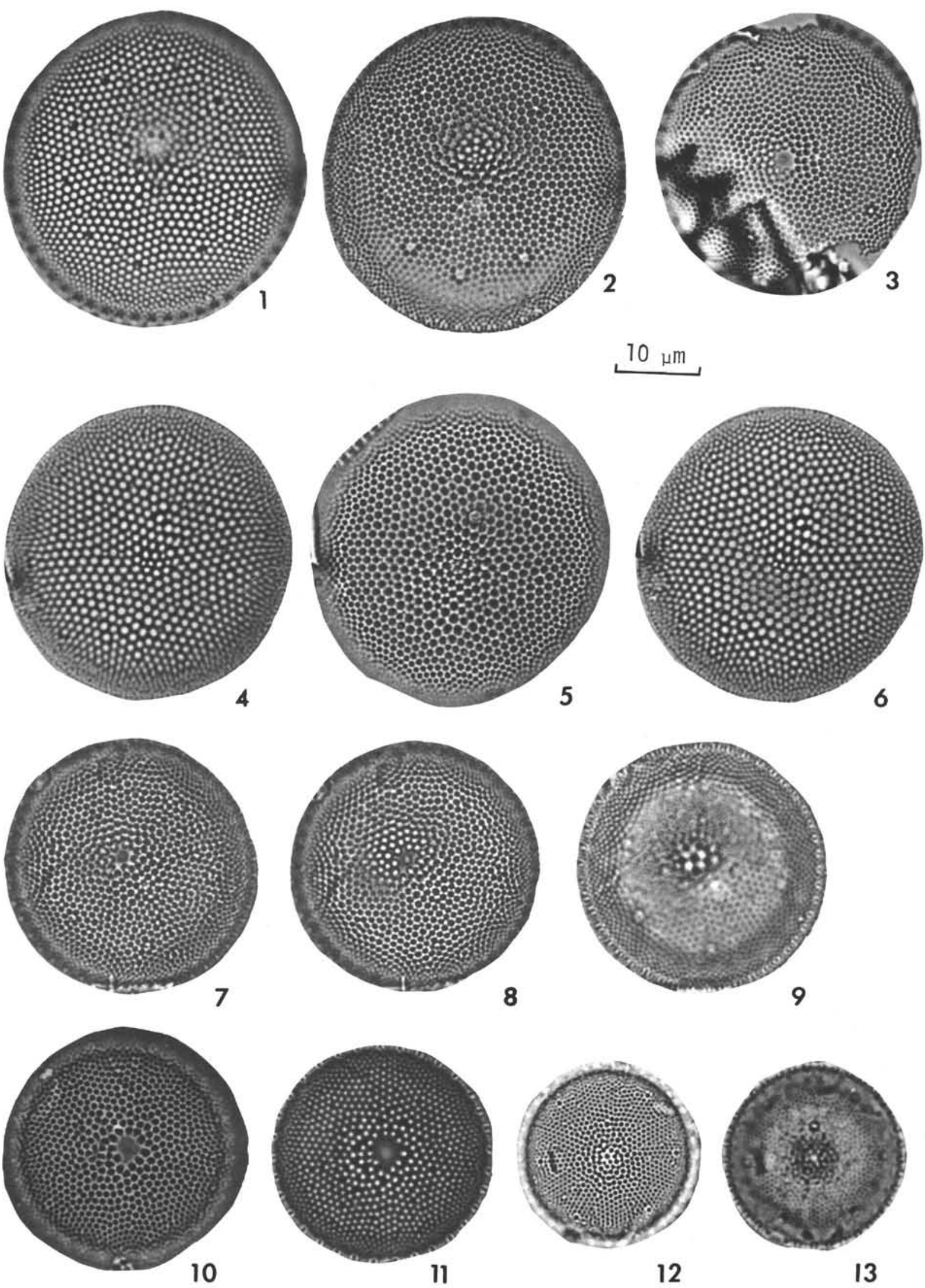

13 
PLATE 4

(Magnification 1500X)

Figures 1-8 Thalassiosira symbolophora $\mathrm{n}$. sp.

1-3. DSDP 238-2, CC (type)

4-6. DSDP 238-2, CC.

7,8 . DSDP $238-3-2,75 \mathrm{~cm}$.

Figures 9, 10 Thalassiosira sp. I Schrader; DSDP 238-19-2, $75 \mathrm{~cm}$.

Figures 11-13 Coscinodiscus cf. lineatus Ehr.; DSDP 238-16-1, $75 \mathrm{~cm}$.

Figures 14-16 Thalassiosira sp. II Schrader; DSDP 238-7-5, $40 \mathrm{~cm}$.

Figures 17-19 Thalassiosira sp. III Schrader; DSDP 238-15-4, $75 \mathrm{~cm}$. 
PLATE 4
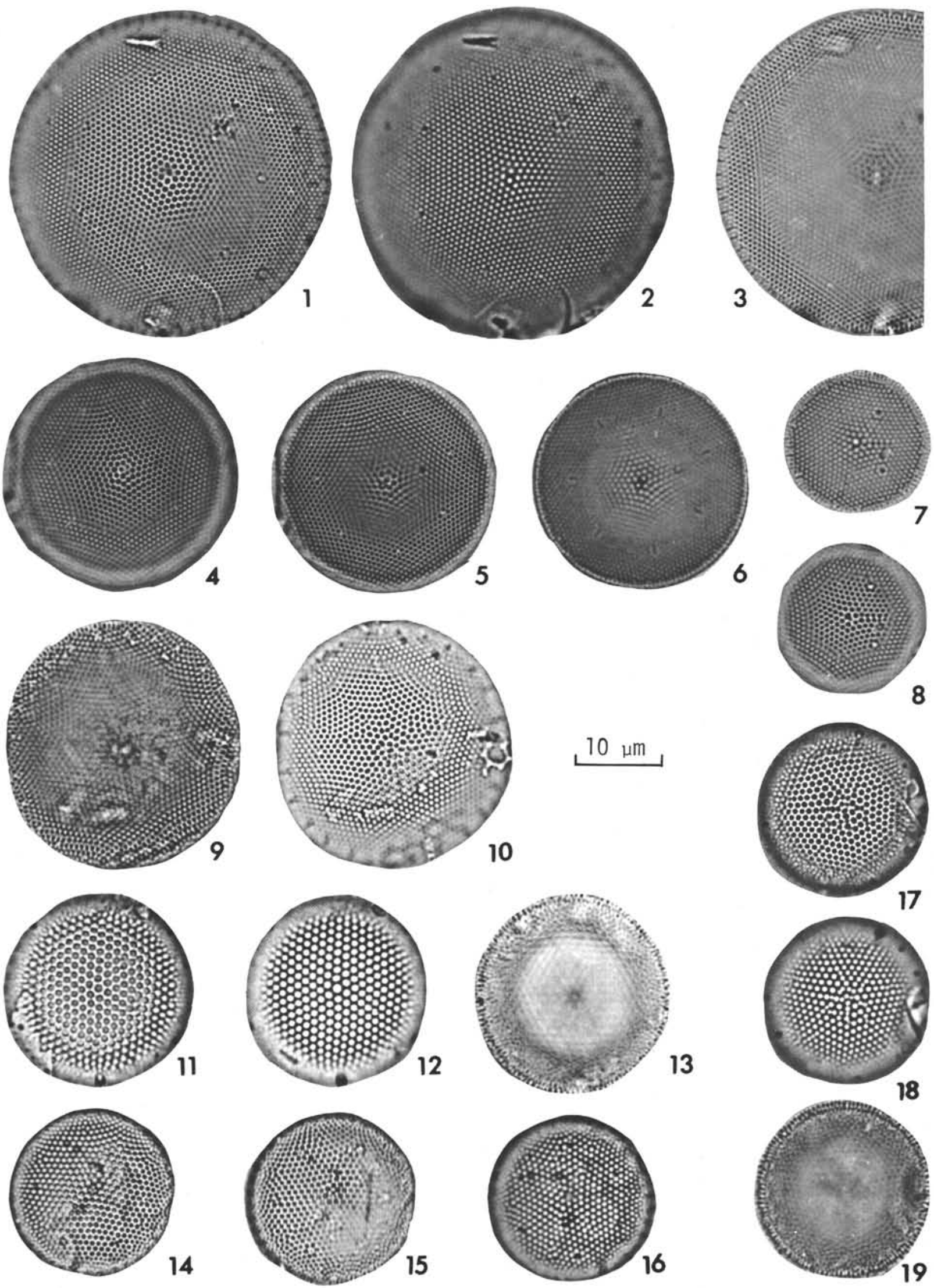
PLATE 5

(Magnification 1500X, unless differently listed)

Figures 1, 2 Nitzschia marina Grunow; DSDP 238-12-2, $70 \mathrm{~cm}$.

Figures 3,4 Nitzschia reinholdii Kanaya and Koizumi; DSDP 238-2-6, $65 \mathrm{~cm}$.

Figure 5 Nitzschia marina Grunow (600X), DSDP 238-12-2, $70 \mathrm{~cm}$.

Figures 6-9 Nitzschia reinholdii Kanaya and Koizumi 6, 7. DSDP 238-5, CC.

8,9 . DSDP $238-7-4,70 \mathrm{~cm}$.

Figures 10,11 Nitzschia miocenica Burckle; DSDP 238-19-2, $75 \mathrm{~cm}$.

Figures 12,13 Nitzschia reinholdii Kanaya and Koizumi; DSDP $238-14-1,75 \mathrm{~cm}$.

Figures 14, 15 Nitzschia cf. marina Grunow; DSDP 238-17-1, $75 \mathrm{~cm}$.

Figures 16,17 Nitzschia indica n. sp. (type); DSDP 238-23, CC.

Figures 18,19 Nitzschia reinholdii Kanaya and Koizumi; DSDP 238-7-5, $40 \mathrm{~cm}$. 
PLATE 5
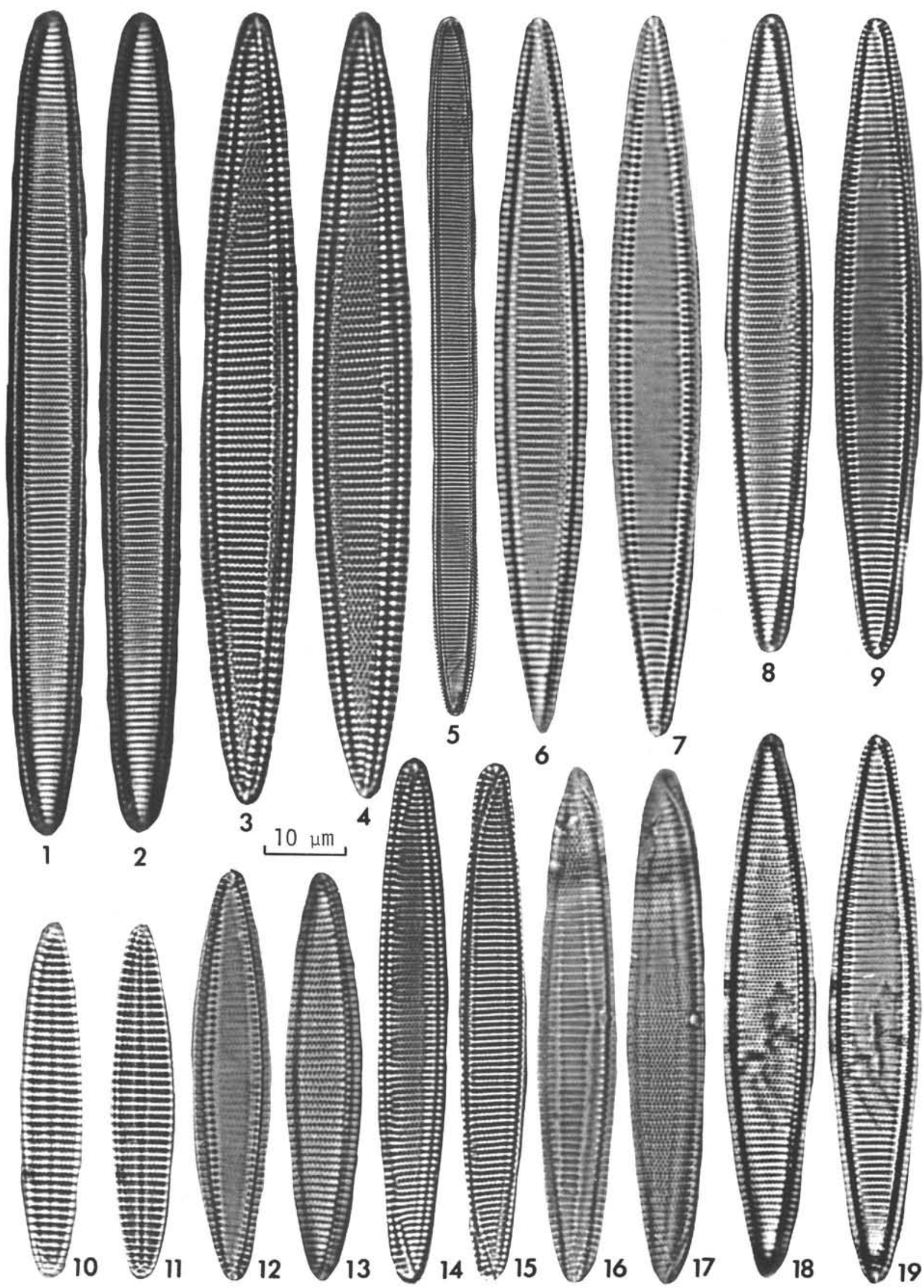


\section{PLATE 6}

(Magnification 1500X)

Figures 1-7 Pseudoeunotia doliolus Grunow

1. DSDP 238-1, CC.

2, 3. DSDP $238-3-1,75 \mathrm{~cm}$.

4. DSDP $238-1-2,75 \mathrm{~cm}$.

5. DSDP $238-6-1,11 \mathrm{~cm}$.

6,7 . DSDP $238-6-4,75 \mathrm{~cm}$.

Figures 8-18 Nitzschia fossilis (Freng.) emend. Kanaya

8,9 . DSDP $238-6-4,75 \mathrm{~cm}$.

10,11. DSDP 238-9-1, $75 \mathrm{~cm}$.

12, 13. DSDP 238-3-2, $75 \mathrm{~cm}$.

14,15 . DSDP $238-10-2,66 \mathrm{~cm}$.

16-18. DSDP $238-8-2,32 \mathrm{~cm}$.

Figures 19,20 Nitzschia cf. fossilis (Freng.) emend. Kanaya; DSDP $238-7-3,60 \mathrm{~cm}$.

Figures 21,22 Nitzschia fossilis (Freng.) emend. Kanaya; DSDP $238-3-6,75 \mathrm{~cm}$.

Figures 23, 24 Nitzschia sp. 1 Schrader; DSDP 238-22, CC.

Figure 25 Nitzschia cylindrica-fossilis (?) transitional form; DSDP 238-21-2, $100 \mathrm{~cm}$.

Figures 26-34 Nitzschia cylindrica Burckle 26. DSDP $238-16-1,75 \mathrm{~cm}$.

27. DSDP $238-21-2,100 \mathrm{~cm}$.

28. DSDP $238-16-1,75 \mathrm{~cm}$. 29, 30. DSDP $238-17-2,75 \mathrm{~cm}$.

31,32 . DSDP $238-17-2,75 \mathrm{~cm}$.

33. DSDP 238-17-1, $75 \mathrm{~cm}$.

34. DSDP $238-21-2,100 \mathrm{~cm}$.

Figure $35 \quad$ Nitzschia cylindrica-fossilis (?) transitional form; DSDP 238-21-2, $100 \mathrm{~cm}$.

Figures 36-38 Nitzschia cylindrica Burckle 36,37 . DSDP $238-28-5,75 \mathrm{~cm}$.

38. DSDP $238-28-5,75 \mathrm{~cm}$. 
PLATE 6

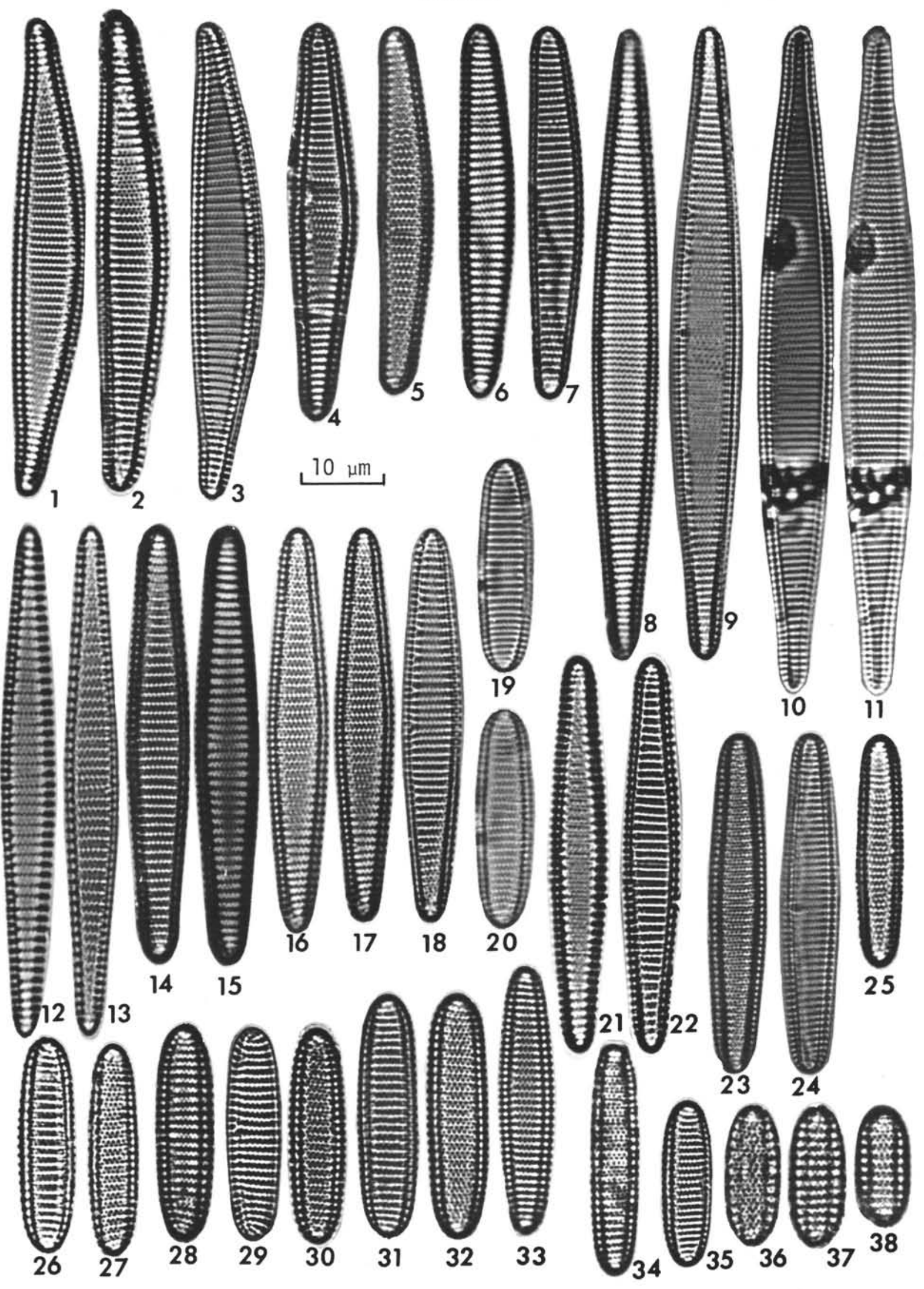


PLATE 7

(Magnification 1500X)

Figures 1-7 Nitzschia marina-miocenica Group, transitional forms.

1,2. DSDP 238-23, CC

3, 4. DSDP $238-22, \mathrm{CC}$.

5-7. DSDP 238-22, CC.

Figures 8,9 Nitzschia cf. marina Grunow; DSDP 238-19-2, $75 \mathrm{~cm}$.

Figures 10,11 Nitzschia reinholdii Kanaya and Koizumi; DSDP $238-12-1,75 \mathrm{~cm}$.

Figures 12, 13 Nitzschia $\cdot$ sp. 2 Schrader; DSDP 238-22-5, $75 \mathrm{~cm}$.

Figures 14-23 Nitzschia jouseae Burckle

14,15 . DSDP $238-4$, CC.

16. DSDP $238-12-2,75 \mathrm{~cm}$.

17, 18. DSDP $238-10$, CC.

19. DSDP $238-12-1,75 \mathrm{~cm}$.

20. DSDP $238-13-3,75 \mathrm{~cm}$.

21. DSDP $238-17-3,75 \mathrm{~cm}$.

22,23 . DSDP $238-15-5,100 \mathrm{~cm}$.

Figures 24-26 Nitzschia praereinholdii Schrader

24. DSDP $238-11-1,37 \mathrm{~cm}$.

25,26 . DSDP 238-11, CC.

Figures 27, 28 Nitzschia praereinholdii-fossilis Group; DSDP 238-7-2, $75 \mathrm{~cm}$.

Figures 29, 30 Nitzschia praereinholdii-jouseae Group;DSDP 238-11, CC. 
PLATE 7

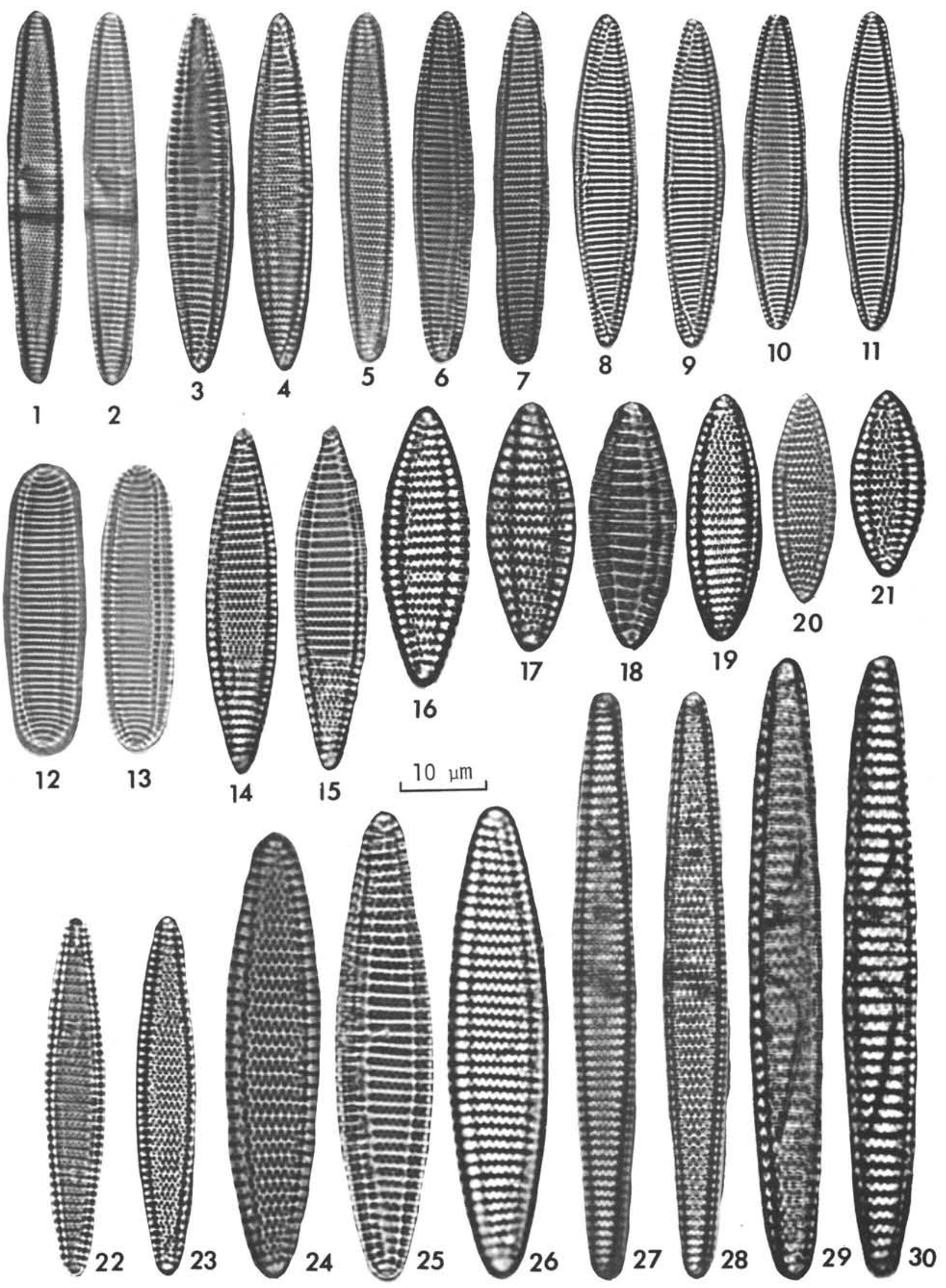


PLATE 8

(Magnification 1500X)

Figure 1

Figure 2

Figure 3

Figure 4

Figure 5

Figure 6

Figure 7
Asteromphalus heptactis (Breb.) Ralfs; DSDP 238. $11-5,90 \mathrm{~cm}$.

Asterolampra marylandica Ehr.; DSDP 238-7-2, $75 \mathrm{~cm}$.

Asteromphalus flabellatus (Breb.) Greville; DSDP $238-3-2,75 \mathrm{~cm}$.

Asteromphalus elegans Greville; DSDP 238-1-5, $65 \mathrm{~cm}$.

Asterolampra grevillei (Wall.) Greville; DSDP 238$11-5,90 \mathrm{~cm}$.

Asteromphalus robustus Castracane; DSDP 238-2-6, $65 \mathrm{~cm}$.

Asteromphalus hookerii Ehr. (?); DSDP 238-3-6, $75 \mathrm{~cm}$. 


\section{PLATE 8}




PLATE 9

(Magnification 1500X)

Figures 1-3 Rhizosolenia praebergonii Muchina

1. DSDP $238-7-4,70 \mathrm{~cm}$.

2. DSDP $238-7-4,70 \mathrm{~cm}$.

3. DSDP $238-7-4,70 \mathrm{~cm}$.

Figure 4 Rhizosolenia bergonii Peragallo;DSDP 238-1-5, $65 \mathrm{~cm}$.

Figure $5 \quad$ Rhizosolenia hebetata forma hiemalis Gran; DSDP $238-17-5,75 \mathrm{~cm}$.

Figure 6 Rhizosolenia firma Karsten; DSDP 238-1, CC.

Figures 7,8 Asterolampra acutiloba Frenguelli; DSDP 238-19-2, $75 \mathrm{~cm}$.

Figure 9 Asteromphalus heptactis (Breb.) Ralfs; DSDP 238$17-1,75 \mathrm{~cm}$.

Figure 10 Asterolampra affinis Greville; DSDP 238-12-2, $70 \mathrm{~cm}$.

Figure 11 Asteromphalus arachne (Breb.) Ralfs; DSDP 238-5-4, $90 \mathrm{~cm}$.

Figures 12, 13 Asteromphalus sp. 1 Schrader; DSDP 238-7-5, $40 \mathrm{~cm}$. 
PLATE 9
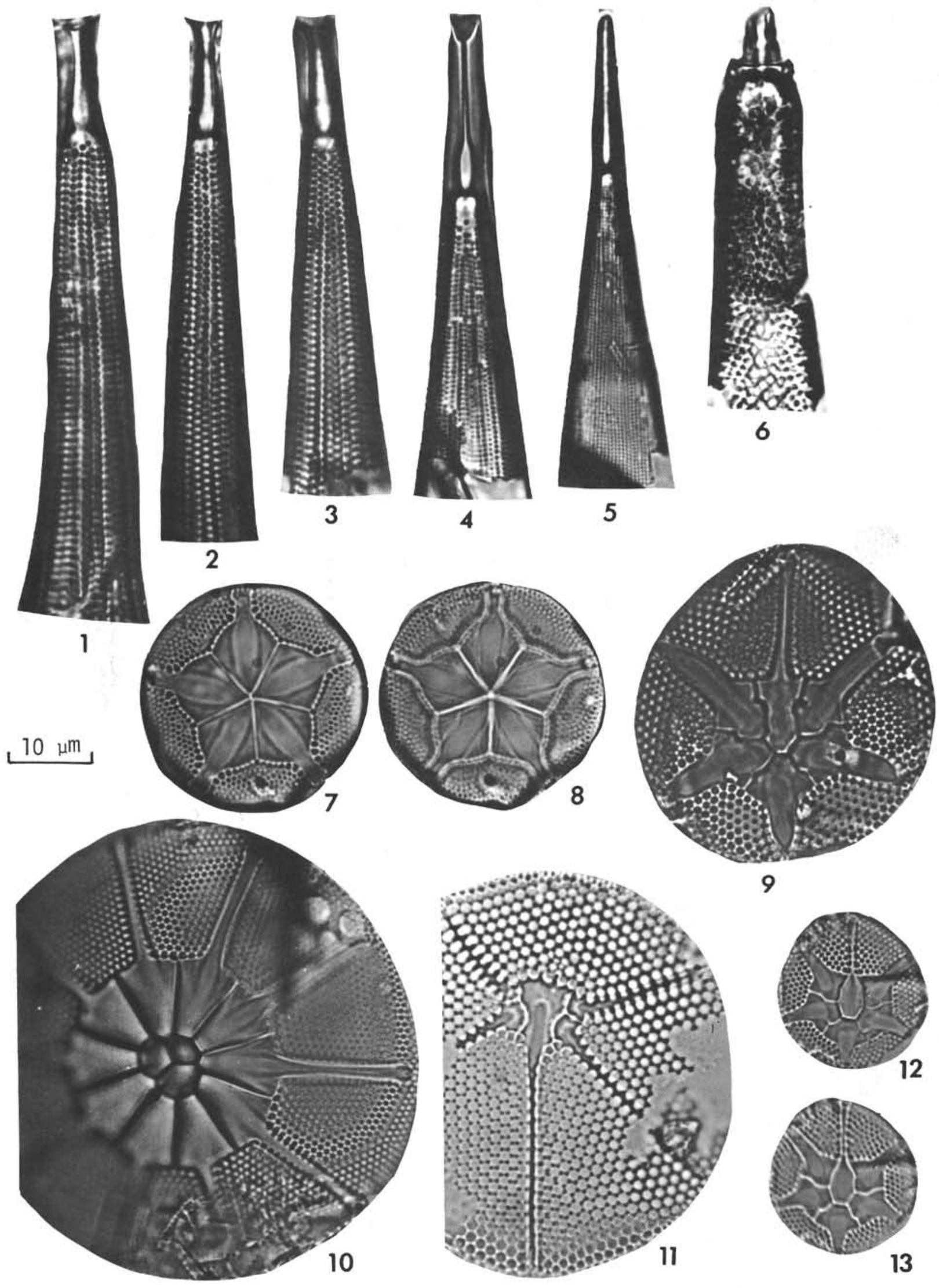
PLATE 10

(Magnification 1500X)

Figures 1-4 Thalassiosira sp. 7 Schrader (Thalassiosira lineata jouse)

1,2. DSDP 238-3-2, $75 \mathrm{~cm}$ (type).

3,4 . DSDP $238-7-2,75 \mathrm{~cm}$.

Figures 5-8 Coscinodiscus lineatus Ehr. var. ellipticus Kolbe 5, 6. DSDP 238-2, CC.

7, 8. DSDP $238-3-6,75 \mathrm{~cm}$.

Figure 9 Thalassiosira sp. Schrader; DSDP 238-1-4, $65 \mathrm{~cm}$.

Figures 10-11 Thalassiosira sp. 6 Schrader; DSDP 238-1-4, $65 \mathrm{~cm}$. 

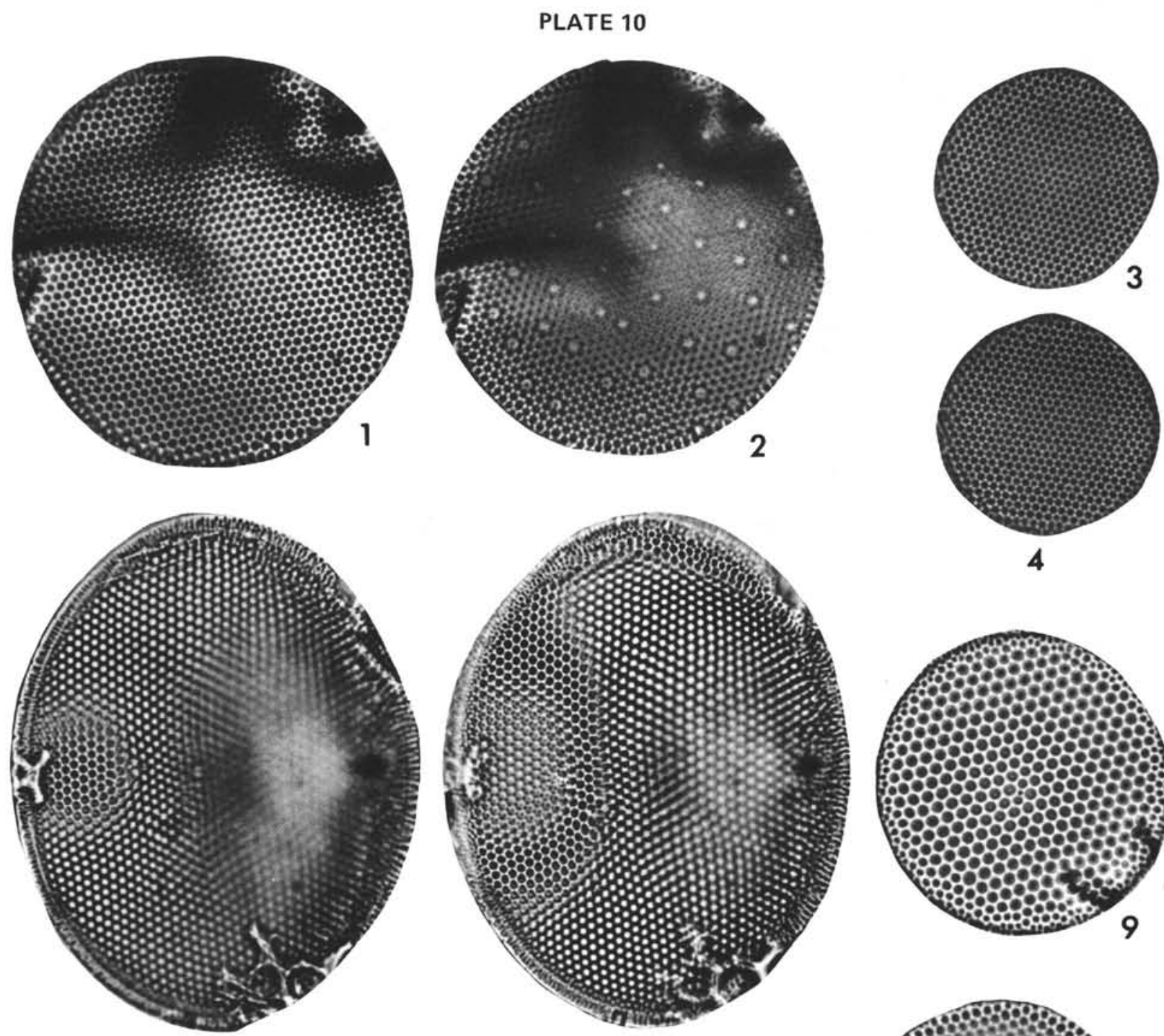

$10 \mu \mathrm{m}$
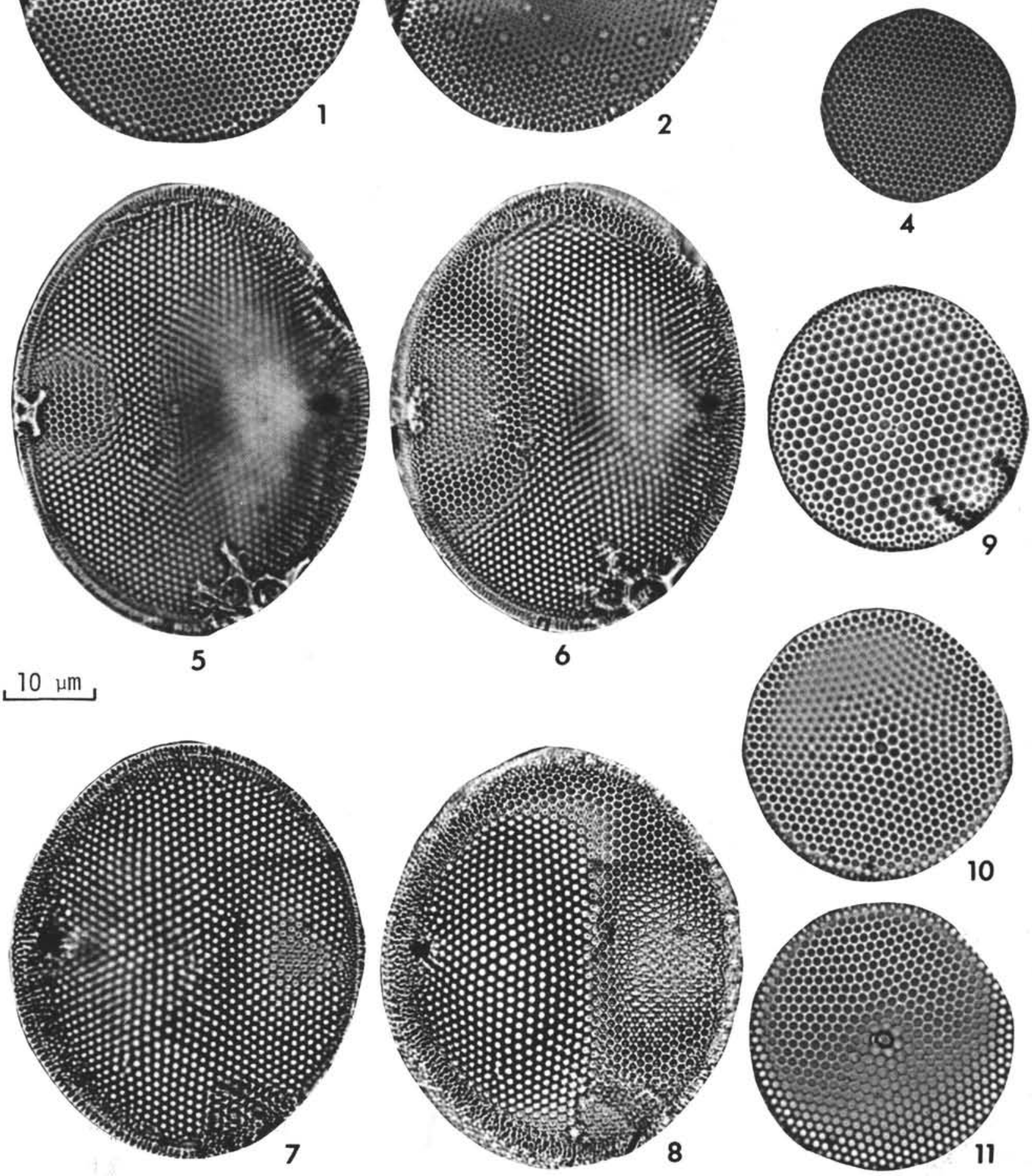
PLATE 11

(Magnification 1500X)

Figures 1,2 Actinocyclus curvatulus Janisch

1. DSDP $238-11-4,10 \mathrm{~cm}$.

2. DSDP $238-13-3,75 \mathrm{~cm}$.

Figures 3, 4 Coscinodiscus cf. lineatus Ehr.; DSDP 238-7-5, $40 \mathrm{~cm}$.

Figure $5 \quad$ Coscinodiscus excentricus Ehr.; DSDP 238-11-4, $10 \mathrm{~cm}$.

Figure 6 Coscinodiscus lineatus Ehr.; DSDP 238-4, CC.

Figures 7, 8 Thalassiosira excentrica (Ehr.) Cleve; DSDP 238-2, CC.

Figures 9-11 Coscinodiscus excentricus Ehr.; DSDP 238-5, CC. 
PLATE 11
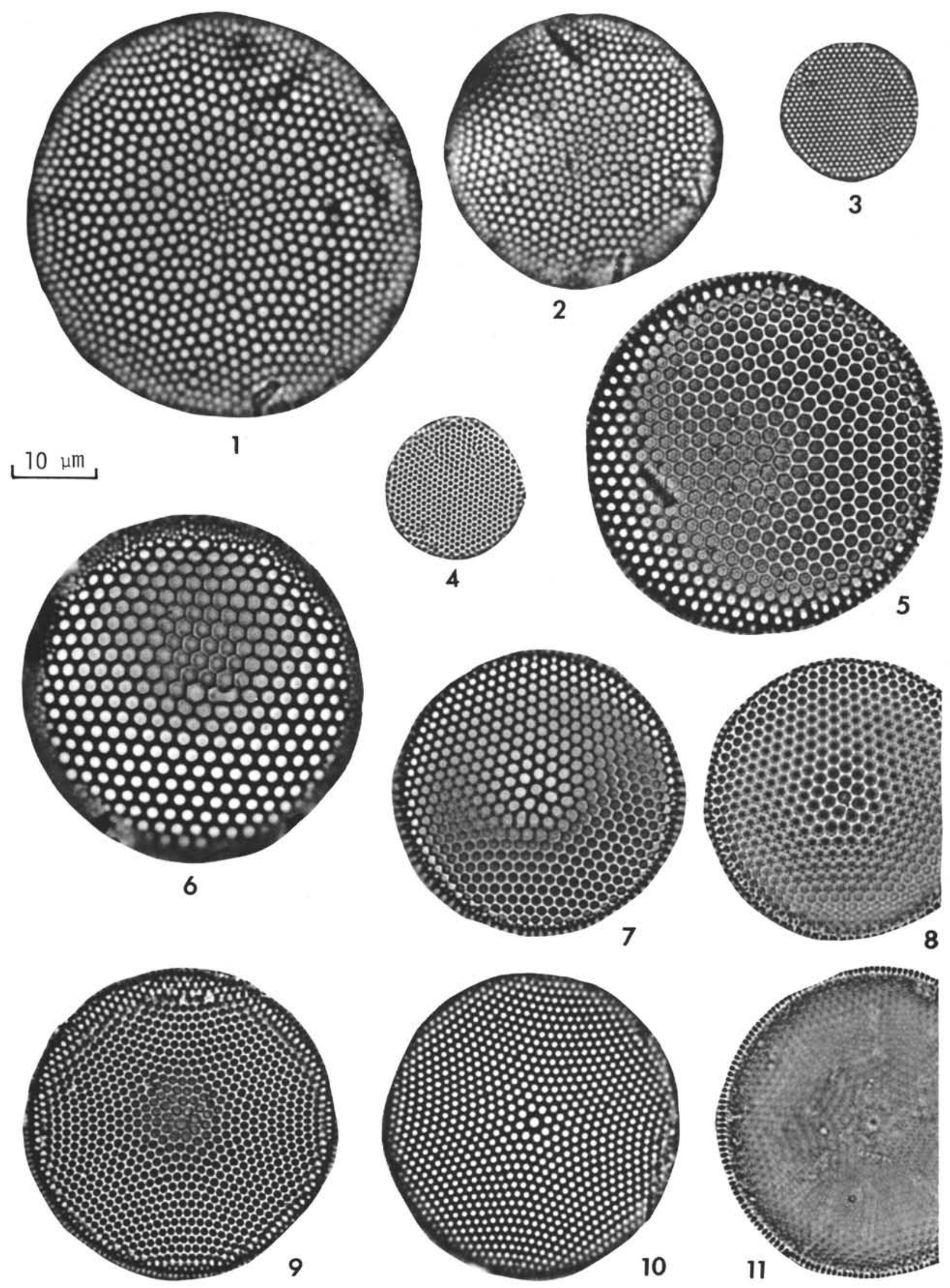


\section{PLATE 12}

Preservation of diatom valves in various Ethmodiscus rex oozes. (Magnification 1500X)

Figures 1-9 Coscinodiscus tabularis GRUNOW var. egregius (Rattray) Hustedt

1. Well-preserved DSDP 238-2, CC.

2. Moderately well preserved DSDP $238-5, \mathrm{CC}$.

3. Moderately preserved DSDP $238-11-6,70 \mathrm{~cm}$.

4. Badly corroded DSDP $238-2-2,75 \mathrm{~cm}$.

5. Badly corroded DSDP $238-7-5,40 \mathrm{~cm}$.

6. Badly corroded DSDP $238-2-2,75 \mathrm{~cm}$.

7. Moderately preserved DSDP $238-3-6,75 \mathrm{~cm}$.

8. Moderately well preserved DSDP $238-3-6,75 \mathrm{~cm}$.

9. Well-preserved DSDP 238-1, CC.

Figures 10-13 Asteromphalus peterssonii (Kolbe) n. comb.

10. Well-preserved DSDP $238-1-2,75 \mathrm{~cm}$.

11. Moderately well preserved DSDP $238-1$, CC.

12. Moderately preserved DSDP $238-2-2,75 \mathrm{~cm}$.

13. Badly corroded DSDP 238-3-1, $75 \mathrm{~cm}$ (Liostephania-stage).

Figures 14, 15 Asteromphalus sp. 1 Schrader

14. Well-preserved DSDP 238-3-1, $75 \mathrm{~cm}$.

15. Badly corroded DSDP 238-7-5, $40 \mathrm{~cm}$ (Liostephania-stage).

Figures 16-19 Asteromphalus various species

16. Moderately preserved DSDP 238-6-4, $75 \mathrm{~cm}$ (Liostephania-stage).

17. Badly corroded DSDP 238-5-4, $90 \mathrm{~cm}$ (Liostephania-stage).

18. Badly corroded DSDP 238-5, CC (Liostephaniastage).

19. Badly corroded DSDP 238-10-2, $66 \mathrm{~cm}$ (Liostephania-stage).

Figures 20,21 Thalassionema nitzschioides Grunow

20. Moderately well preserved DSDP $238-4-1,75 \mathrm{~cm}$. 21. Badly corroded DSDP $238-2-2,75 \mathrm{~cm}$.

Figures 22, 23 Asterolampra

22. Badly corroded DSDP 238-10-1, $60 \mathrm{~cm}$ (Liostephania-stage).

23. Badly corroded DSDP 238-10-6, $50 \mathrm{~cm}$ (Liostephania -stage).

Figure $24 \quad$ Asteromphalus sp. Badly corroded DSDP 238-5-4, 60 $\mathrm{cm}$ (Liostephania-stage). 
PLATE 12
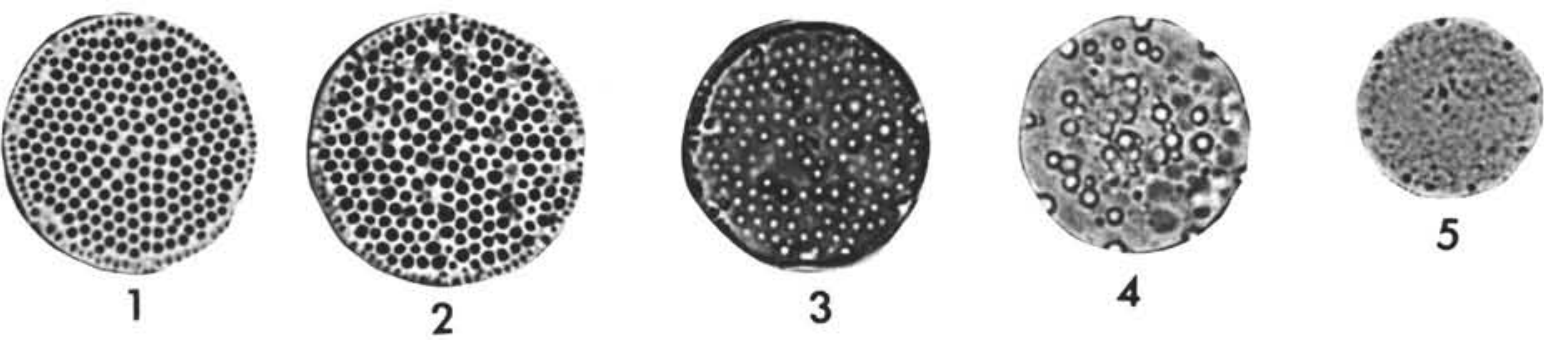

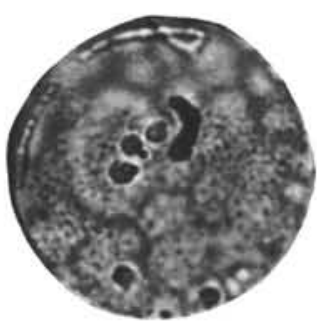

6

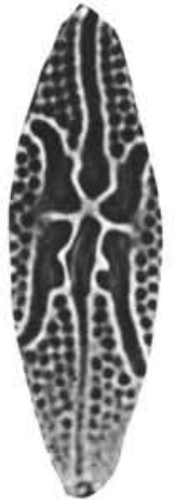

10

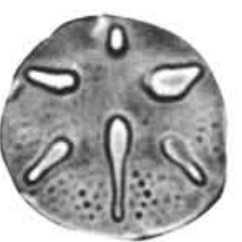

17

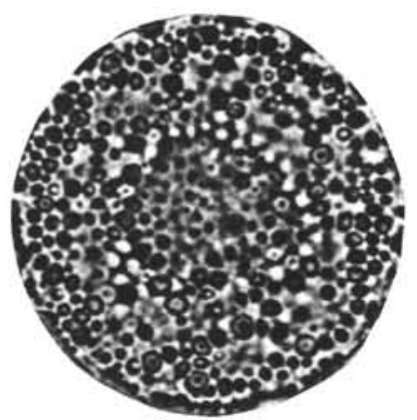

7

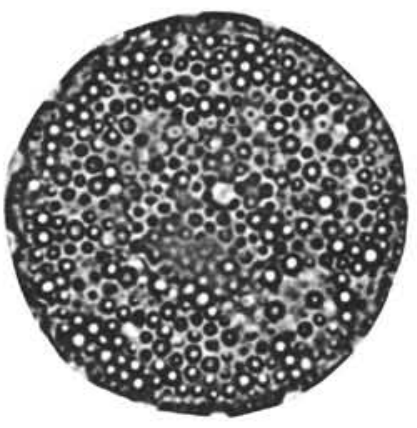

8

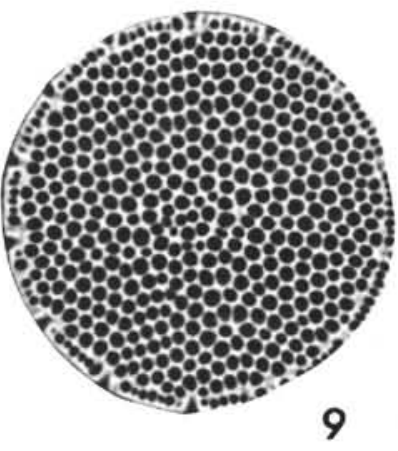

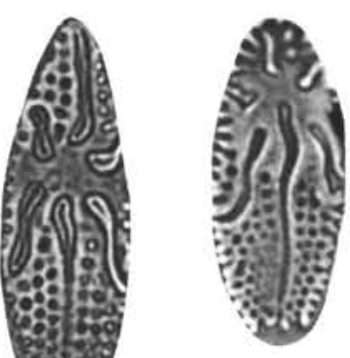

12

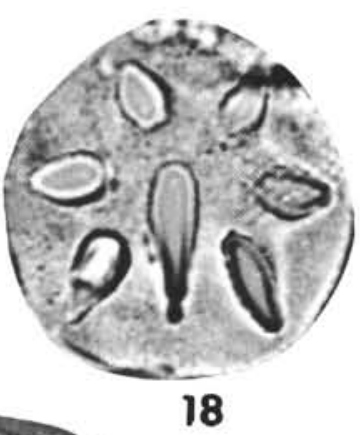

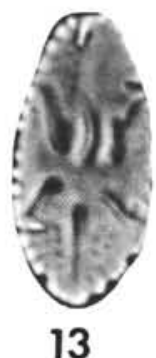

13

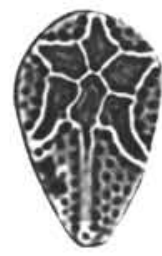

14
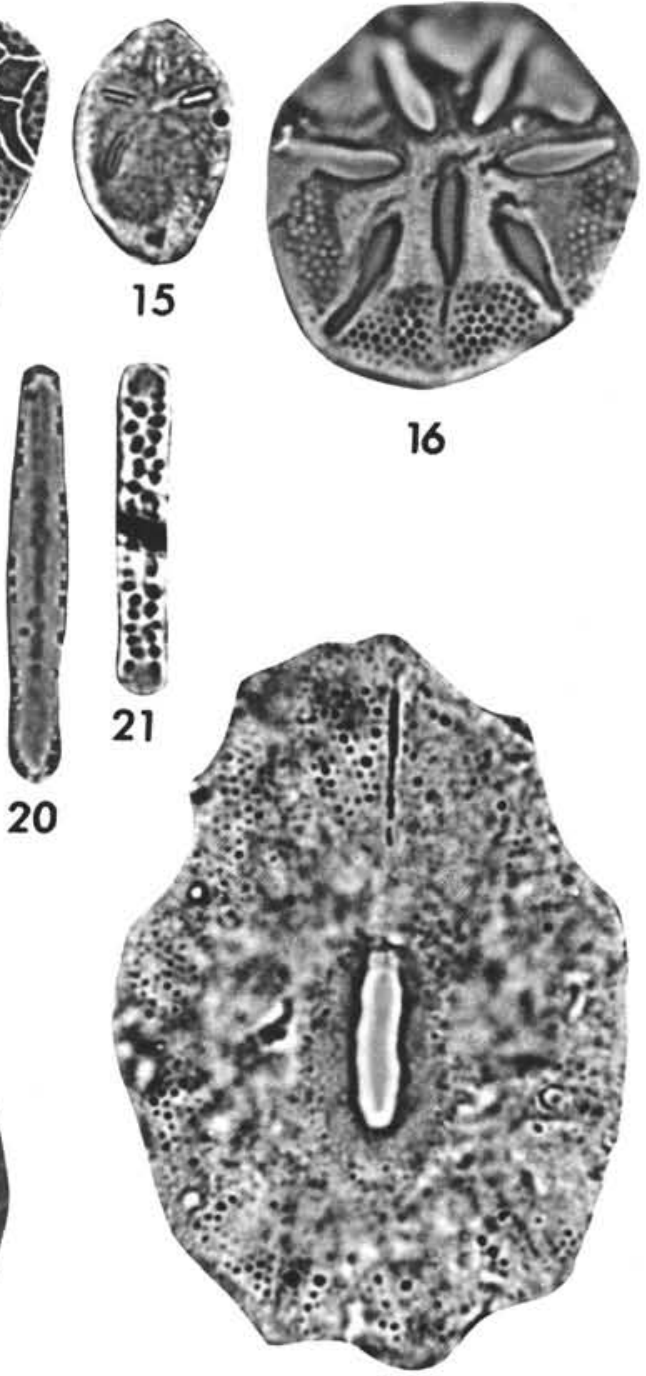

24
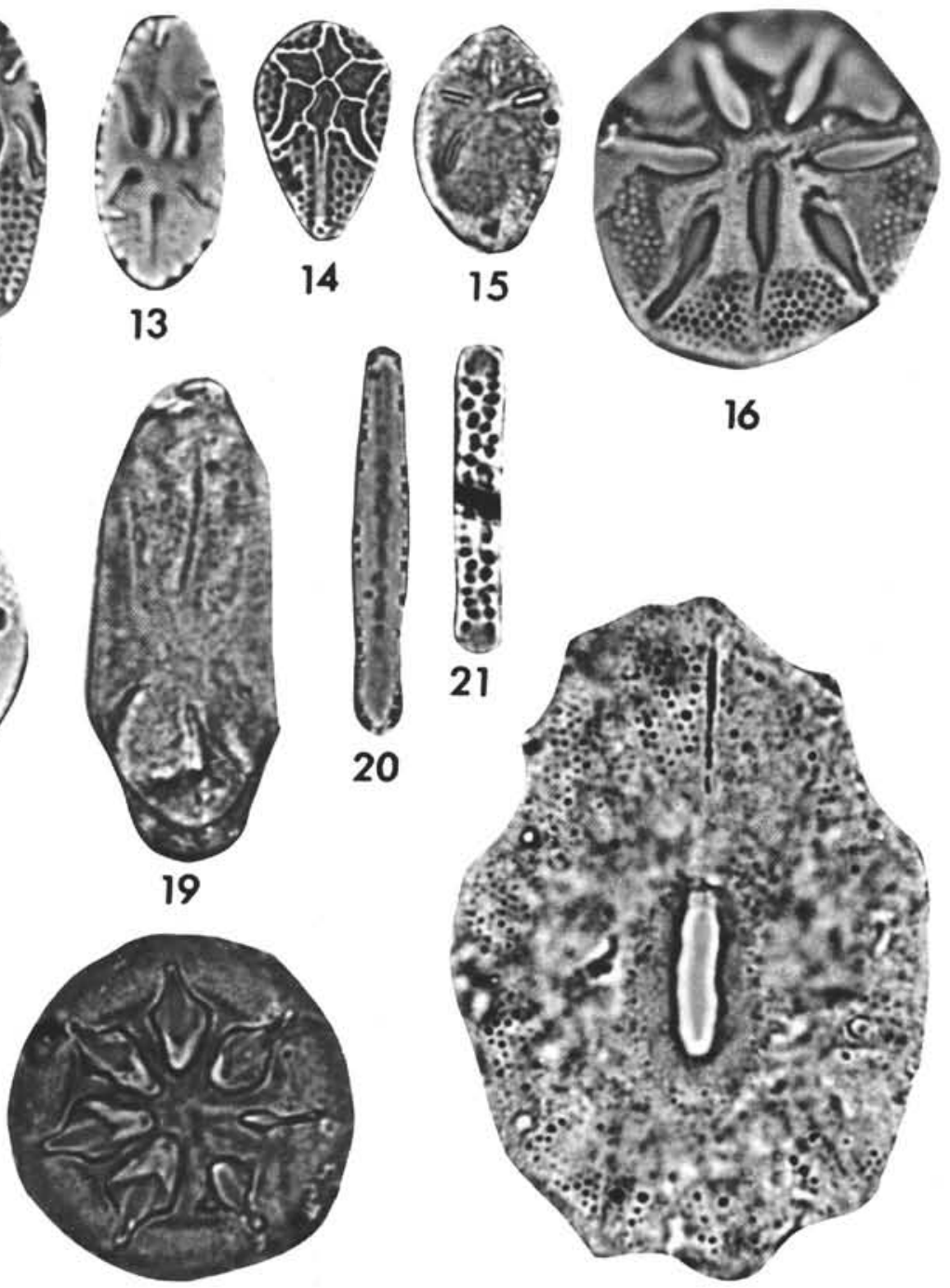

23 
PLATE 13

(Magnification 1500X)

Chert formation (?), piece of about $1 \mathrm{~mm}$ diameter flat chert from DSDP 238-4, CC showing preservation and mobilization of opaline silica. Upper part with well-preserved (partly broken: Ethmodiscus rex, Nitzschia reinholdii, Thalassionema nitzschioides, radiolarians and sponge spicules); middle part with compacted frustules (mostly broken: Thalassionema nitzschioides, Thalassiothrix longissima); lower part with few recognizable diatom fragments. Balsam mount; plain transmitted light. 
PLATE 13

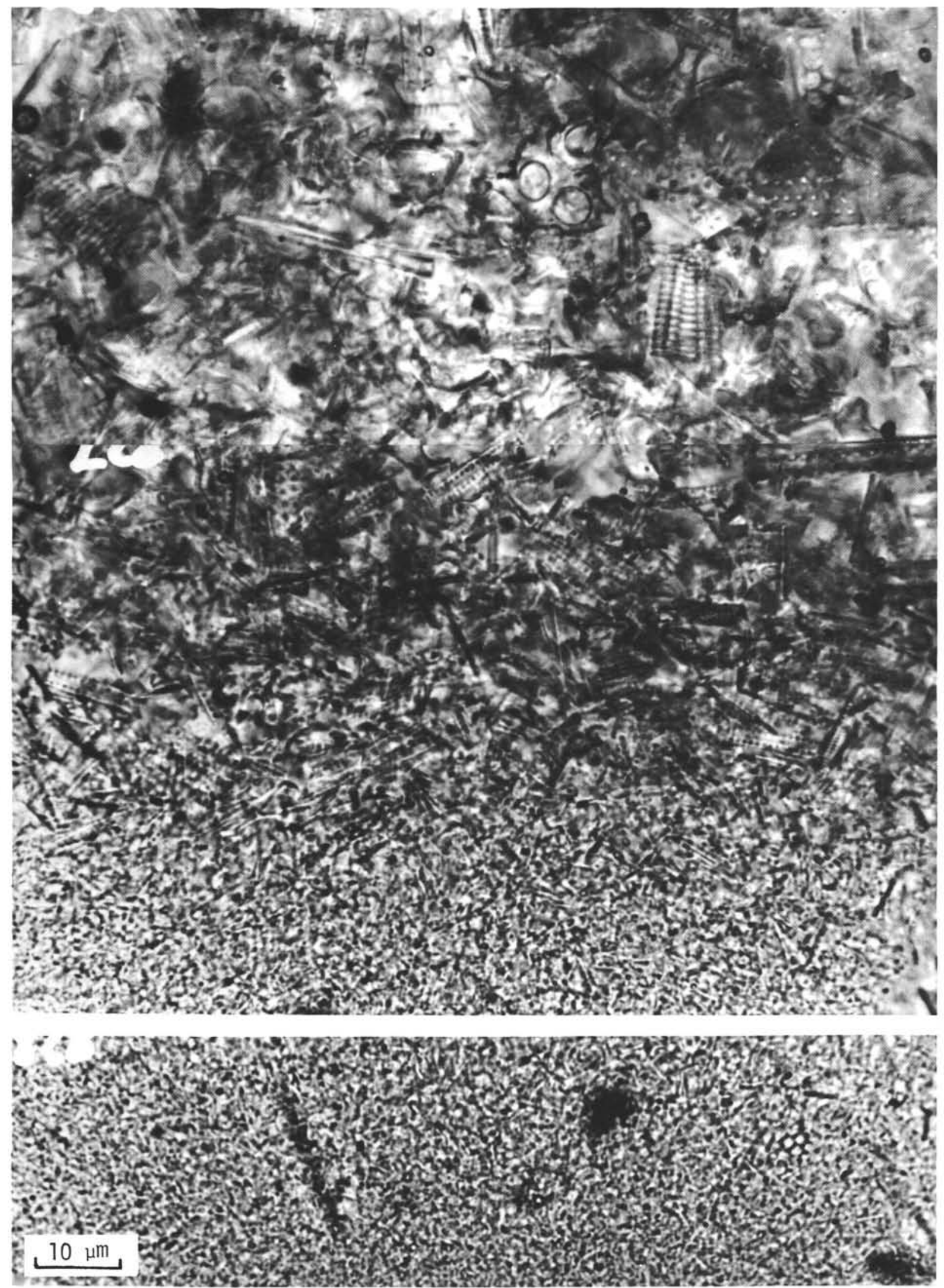


PLATE 14

(Magnification 1500X)

Figures 1, 2 Coscinodiscus excentricus Ehr.; DSDP 238-7-5, 40 $\mathrm{cm}$.

Figures 3, $4 \quad$ Roperia praetesselata $\mathrm{n}$. sp.; DSDP 238-12-1, $75 \mathrm{~cm}$.

Figure 5 Thalassiosira oestrupii (Ostenf.) Proskina-Lavrenko; DSDP 238-11-2, $12 \mathrm{~cm}$.

Figures 6,7 Thalassiosira cf. excentrica (Ehr.) Cleve; DSDP 238-12, CC.

Figure $8 \quad$ Coscinodiscus excentricus Ehr.; DSDP 238-1, CC (no central strutted tubulus).

Figures 9, 10 Thalassiosira excentrica (Ehr.) Cleve; DSDP 238-7-5, $40 \mathrm{~cm}$ (central strutted tubulus present). 
PLATE 14

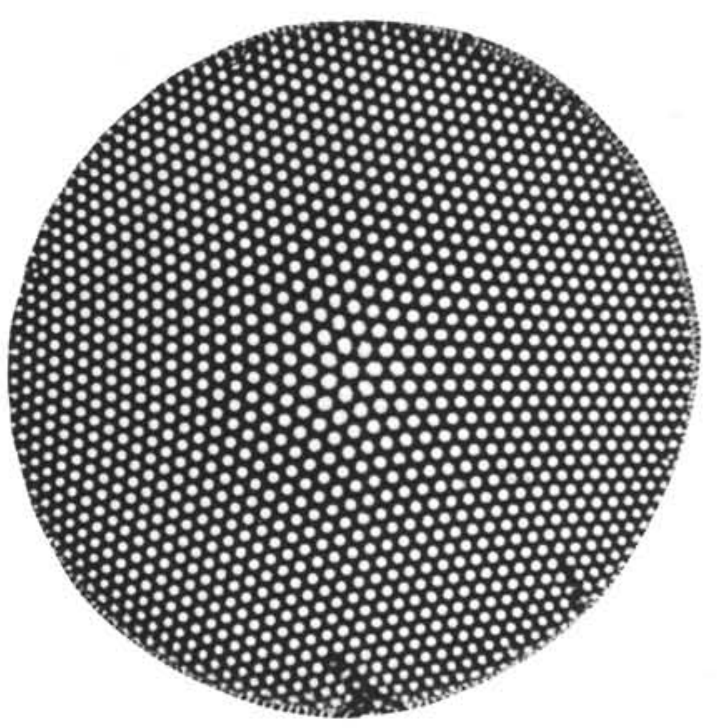

1

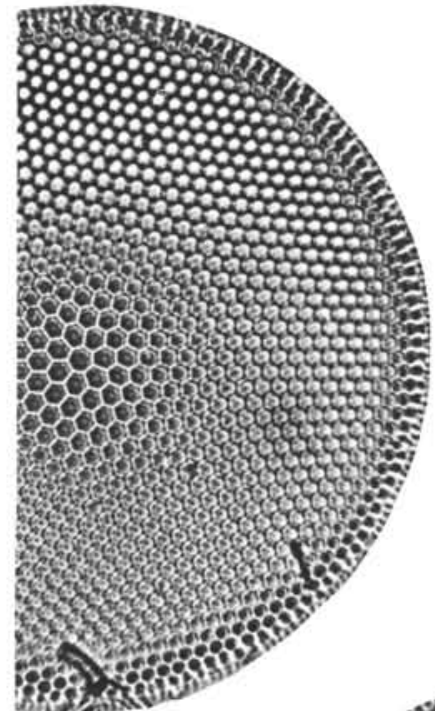

2

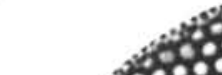

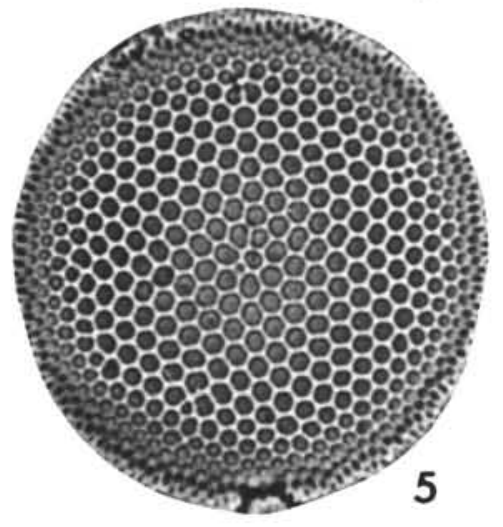

$10 \mu \mathrm{m}$

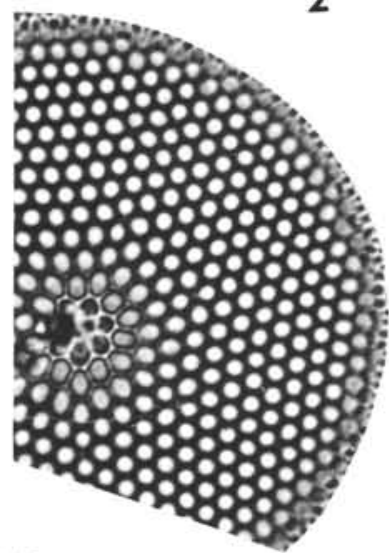

6

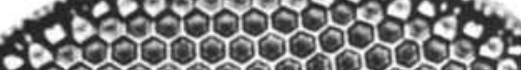
- 20000000001

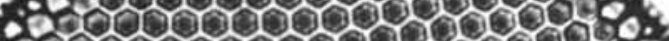

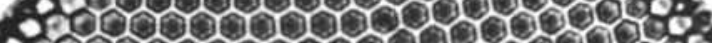
รOD

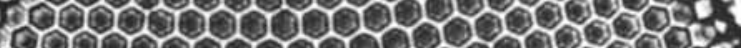
-

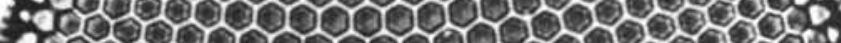
* -cos aco 0 O

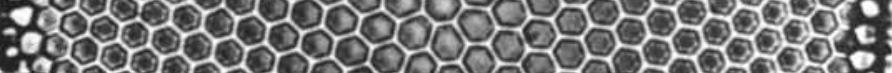
\% HO (8)

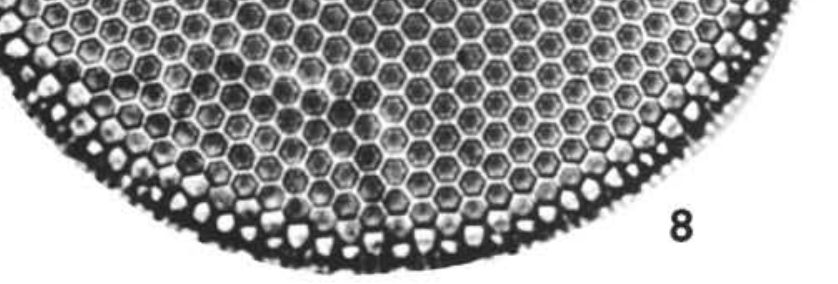
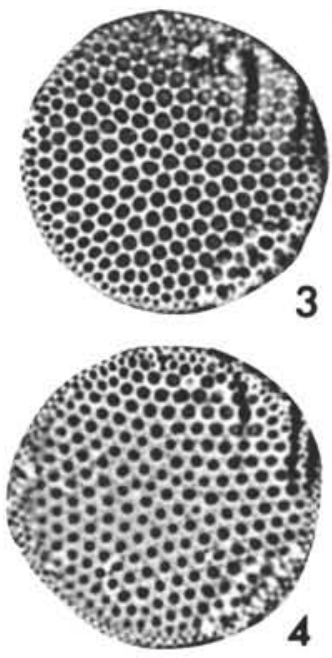

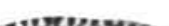
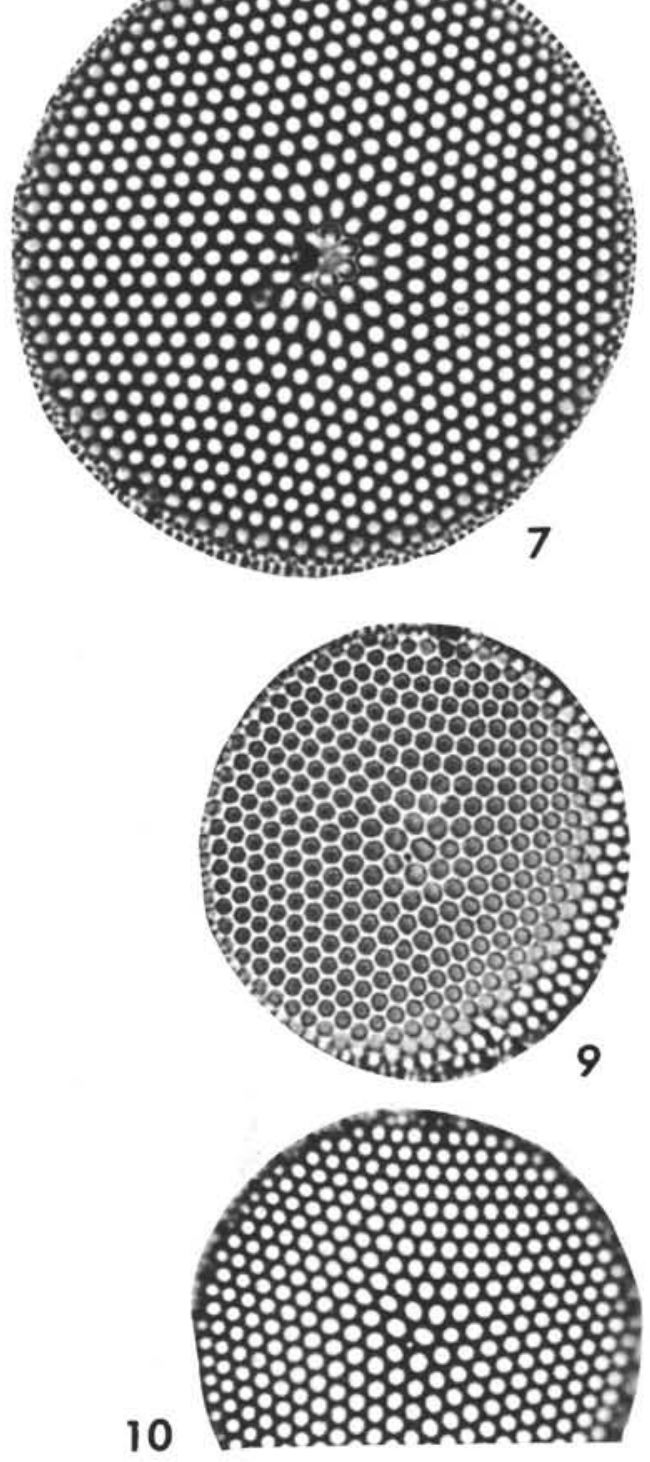


\section{PLATE 15 , (Magnification 1500X)}

Figures 1-7 Nitzschia interrupta Heiden

1,2. DSDP 238-5, CC.

3,4. DSDP $238-12, \mathrm{CC}$

5-7. DSDP $238-7-5,40 \mathrm{~cm}$.

Figures 8, $9 \quad$ Nitzschia cf. interrupta Heiden; DSDP 238-24, CC.

Figures 10, 11 Nitzschia interrupta Heiden; DSDP 238-11, CC.

Figures 12, 13 Nitzschia sp. 4 Schrader; DSDP 238-15-4, $75 \mathrm{~cm}$.

Figure $14 \quad$ Nitzschia porteri Frenguelli; DSDP 238-22-5, $75 \mathrm{~cm}$.

Figure $15 \quad$ Nitzschia sp. 13 Schrader; DSDP 238-13-3, $75 \mathrm{~cm}$.

Figures 16-20 Nitzschia sp. 8 Schrader 16,17 . DSDP $238-16-1,75 \mathrm{~cm}$. 18-20. DSDP 238-14-5, $75 \mathrm{~cm}$.

Figures 21, 22 Coscinodiscus plicatus Grunow; DSDP 238-17-2, 75 $\mathrm{cm}$.

Figures 23, 24 Coscinodiscus plicatus Group 1; DSDP 238-10-1, 60 $\mathrm{cm}$.

Figures 25, 26 Coscinodiscus plicatus Grunow 25. DSDP $238-15-5,75 \mathrm{~cm}$. 26. DSDP $238-15-5,100 \mathrm{~cm}$.

Figures 27, 28 Coscinodiscus plicatus Group 2; DSDP 238-17-2, 75 $\mathrm{cm}$.

Figures 29-32 Coscinodiscus plicatus Group 3 29,30 . DSDP $238-15-1,75 \mathrm{~cm}$. 31,32 . DSDP $238-11-6,70 \mathrm{~cm}$. 
PLATE 15
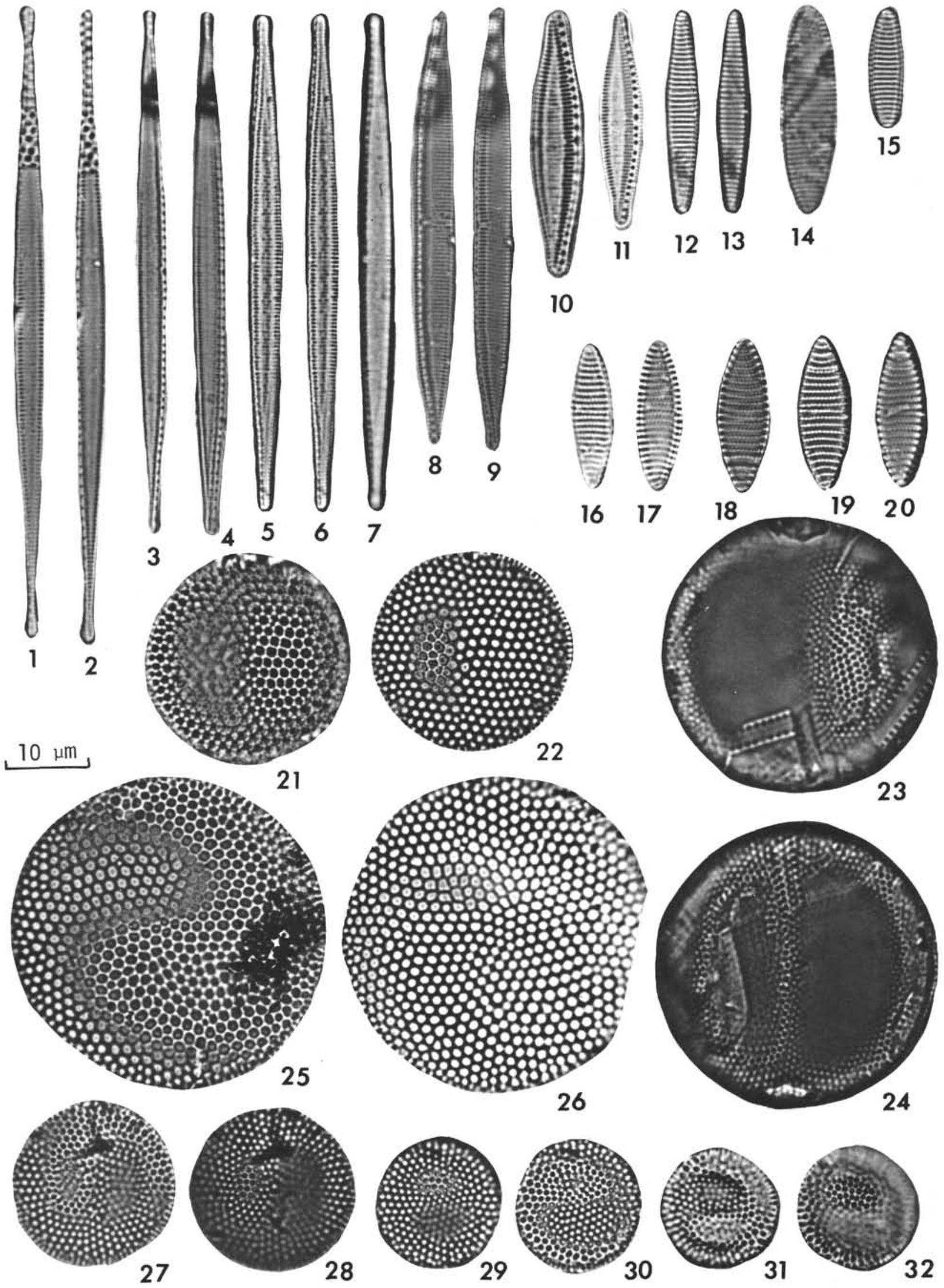
PLATE 16

(Magnification 1500X)

Figures 1-4 Coscinodiscus plicatus Group 4

1,2 . DSDP $238-3-1,75 \mathrm{~cm}$.

3,4 . DSDP $238-15-5,100 \mathrm{~cm}$.

Figures 5,6 Coscinodiscus plicatus Group 5; DSDP 238-5, CC.

Figures 7, 8 Coscinodiscus plicatus Group 6; DSDP 238-3-1, 75 $\mathrm{cm}$.

Figures 9-15 Coscinodiscus plicatus Grunow 9, 10. DSDP 238-17-5, $75 \mathrm{~cm}$. 11, 12. DSDP 238-27-2, $125 \mathrm{~cm}$. 13-15. DSDP $238-12-4,70 \mathrm{~cm}$. 
PLATE 16
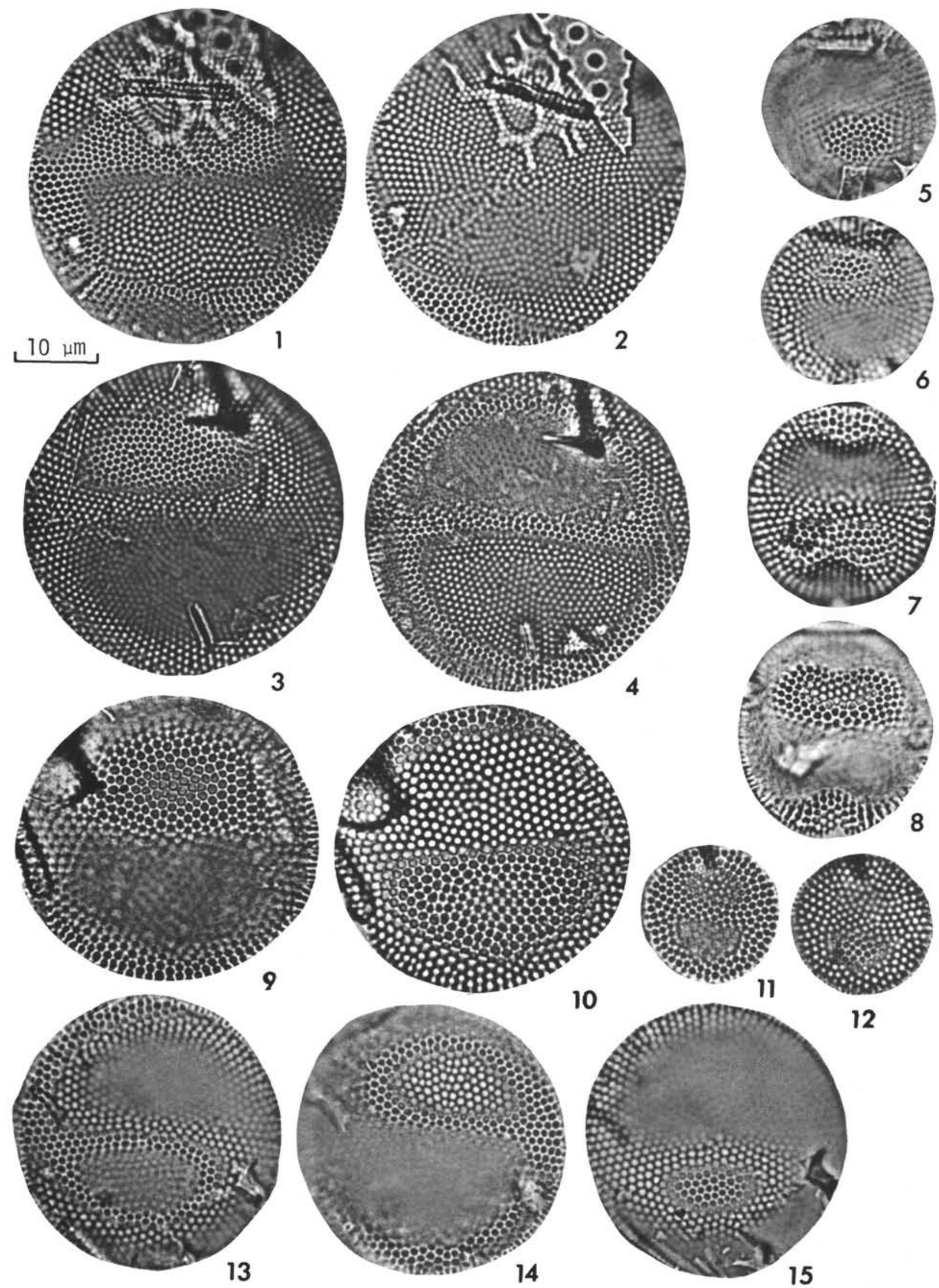
PLATE 17

(Magnification 1500X, unless differently listed)

Figure 1 Astinocyclus ellipticus Grunow var. elongatus (Grun.) Kolbe; DSDP 238-3-2, $75 \mathrm{~cm}$.

Figure 2 Actinocyclus ellipticus Grunow forma lanceolata Kolbe; DSDP 238-21-2, $100 \mathrm{~cm}$.

Figure 3 Actinocyclus ellipticus Grunow var. elongatus (Grun.) Kolbe; DSDP 238-14-1, $75 \mathrm{~cm}$; magnification 600X.

Figure 4 Actinocyclus ellipticus Grunow; DSDP 238-1, CC.

Figure $5 \quad$ Actinocyclus ellipticus Grunow; DSDP 238-28-5, 75 $\mathrm{cm}$.

Figures 6-8 Actinocyclus ellipticus Grunow forma

6. DSDP $238-11-6,70 \mathrm{~cm}$.

7. DSDP $238-17-3,75 \mathrm{~cm}$.

8. DSDP 238-5, CC.

Figures 9-12 Actinocyclus moronensis Deby

9. DSDP $238-11-6,70 \mathrm{~cm}$.

10. DSDP $238-3-6,75 \mathrm{~cm}$.

11. DSDP 238-3-1, $75 \mathrm{~cm}$.

12. DSDP $238-16-5,10 \mathrm{~cm}$.

Figure 13 Actinocyclus ellipticus Grunow var. javanicus Reinhold; DSDP 238-23, CC.

Figures 14,15 Actinocyclus ellipticus spec. 1 Schrader; DSDP 238-23, CC.

Figure 16 Actinocyclus ellipticus Grunow; DSDP 238-27-2, 125 $\mathrm{cm}$. 
PLATE 17
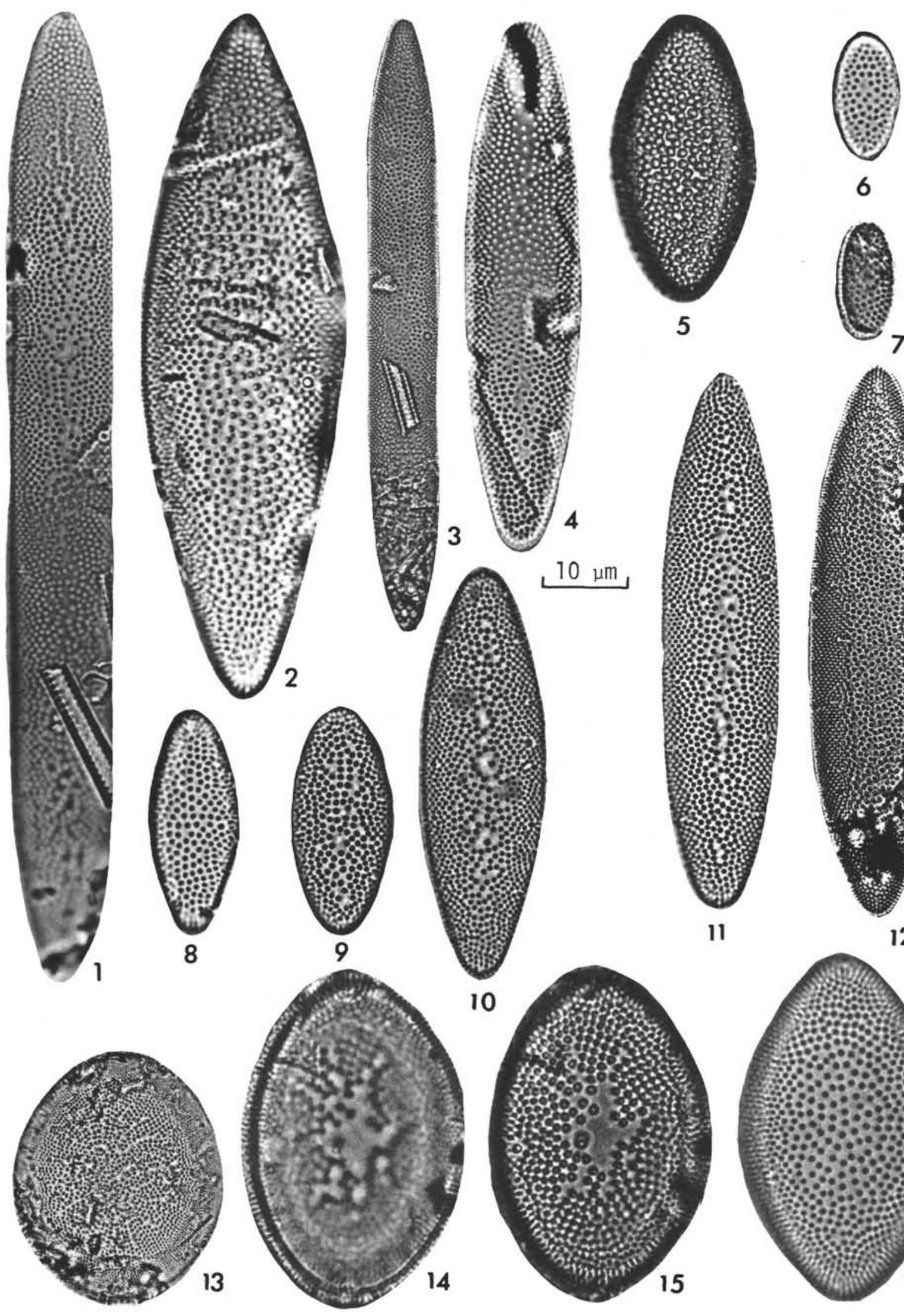

11

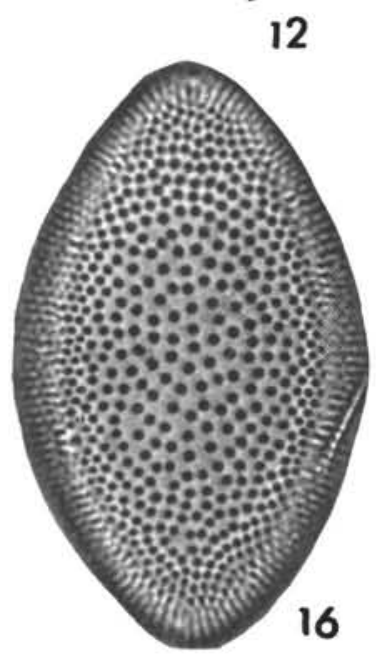


PLATE 18

(Magnification 1500X)

Figures 1, 2 Coscinodiscus africanus Janisch

1. DSDP 238-11, CC.

2. DSDP $238-3-1,75 \mathrm{~cm}$.

Figures 3,4 Coscinodiscus tabularis Grunow var. egregius Rattray; DSDP 238-8-2, $32 \mathrm{~cm}$.

Figures 5-7 Coscinodiscus endoi Kanaya

5. DSDP 238-17-2, $75 \mathrm{~cm}$.

6. DSDP $238-16-3,110 \mathrm{~cm}$.

7. DSDP $238-21-4,100 \mathrm{~cm}$.

Figure 8 Coscinodiscus cf. gigas var. diorama (Schmidt) Grunow; DSDP 238-2, CC.

Figure 9 Coscinodiscus tabularis Grunow var. egregius (Rattray) Hustedt; DSDP 238-17-3, $75 \mathrm{~cm}$.

Figures 10,11 Denticula hustedtii Simonsen and Kanaya; DSDP $238-30$, CC.

Figure 12 Cussia sp. 1 Schrader; DSDP 238-6-4, $75 \mathrm{~cm}$. 


\section{PLATE 18}

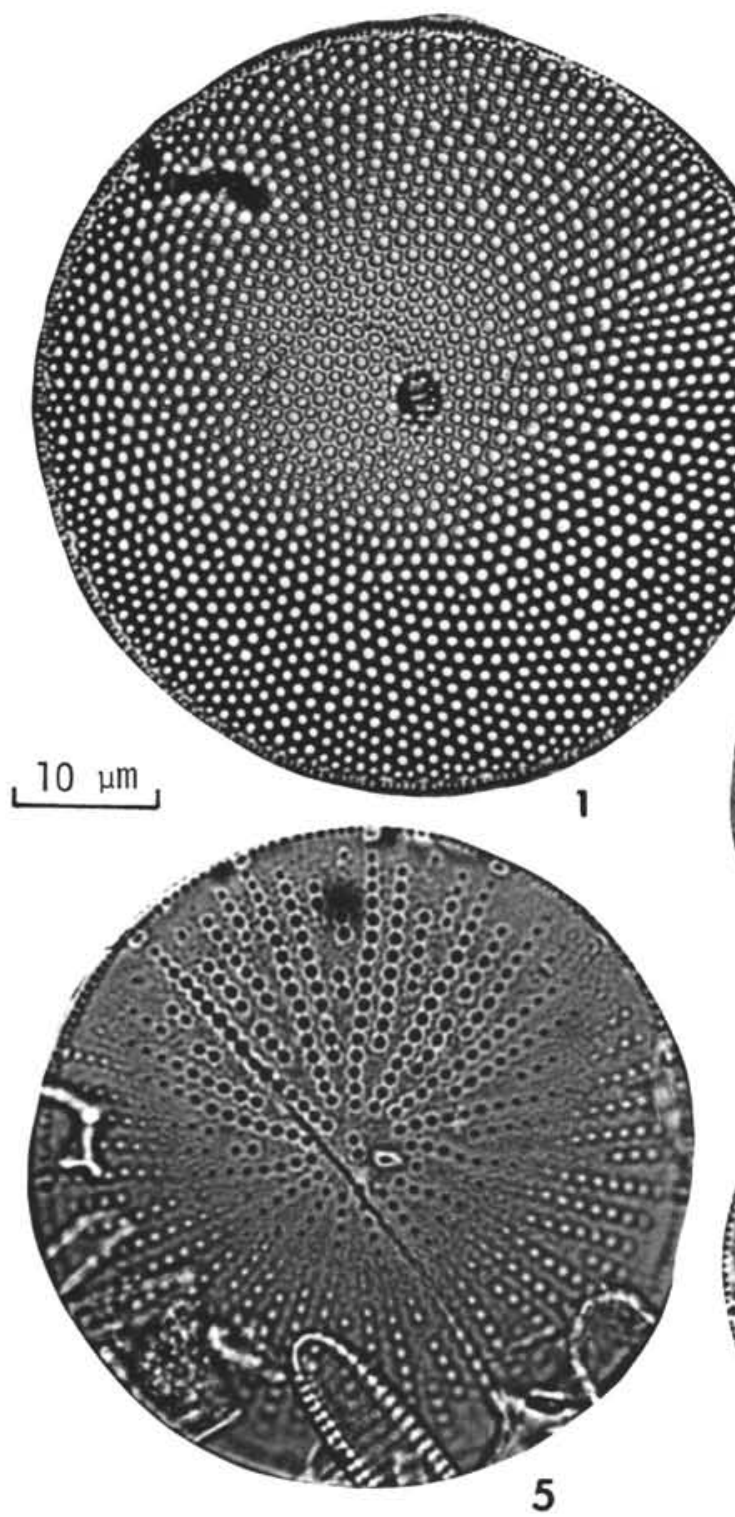

5

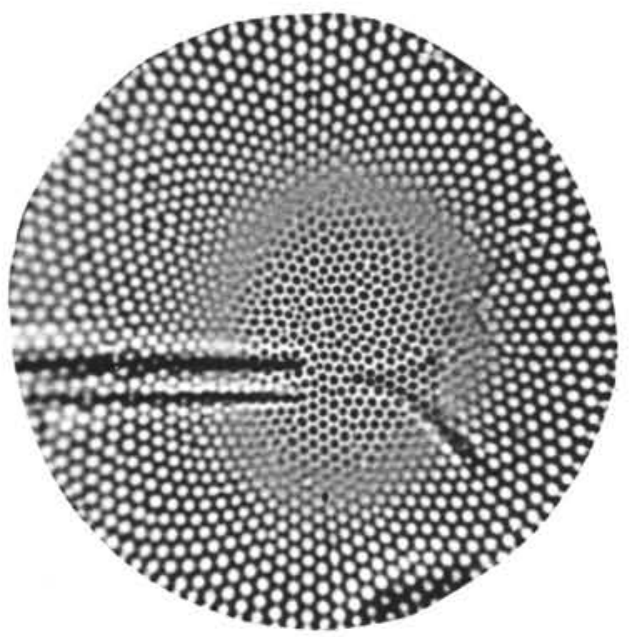

8
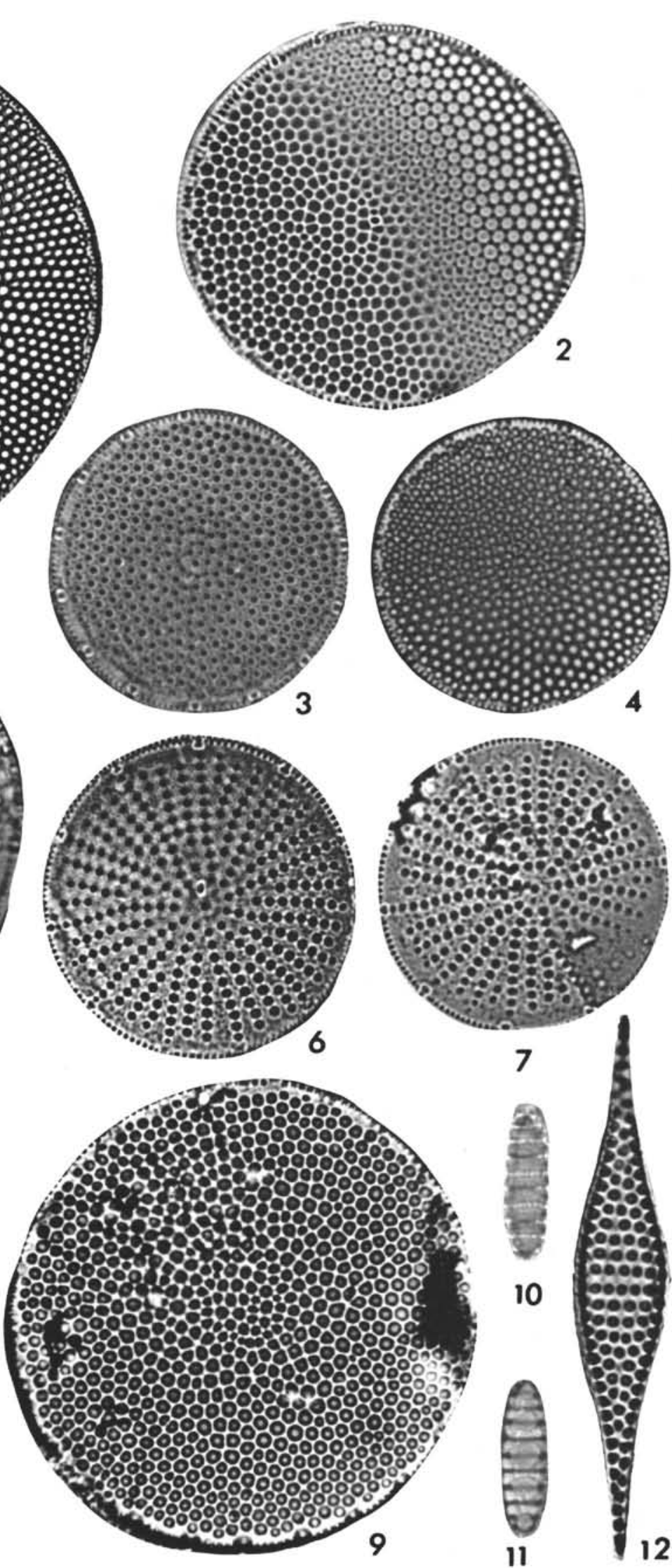
PLATE 19

(Magnification 1500X)

Figure 1 Anaulus sp. 1 Schrader; DSDP 238-23-2, $75 \mathrm{~cm}$.

Figures 2, 3 Biddulphia moholensis Schrader

2. DSDP 238-24, CC.

3. DSDP $238-7-5,40 \mathrm{~cm}$.

Figures 4, $5 \quad$ Thalassionema lineata Jouse

4. DSDP $238-21-2,100 \mathrm{~cm}$.

5. DSDP $238-27-2,125 \mathrm{~cm}$.

Figure 6 Thalassionema nitzschioides Grunow; DSDP 238-23, CC.

Figures 6a, 7 Thalassiothrix longissima Cleve and Grunow; DSDP $238-13-3,75 \mathrm{~cm}$.

Figures 8-10 Thalassiothrix monospina $\mathrm{n}$. sp.

8. DSDP 238-13-3, $75 \mathrm{~cm}$.

9. DSDP 238-22, CC.

10. DSDP $238-19-2,75 \mathrm{~cm}$.

Figure 10a Coscinodiscus tabularis Grunow var. egregius (Rattray) Hustedt; DSDP 238-27-2, $125 \mathrm{~cm}$.

Figures 11-13 Triceratium cinnamomeum Grev. var. minor Grunow 11. DSDP 238-3-1, $75 \mathrm{~cm}$.

12, 13. DSDP $238-3-1,75 \mathrm{~cm}$

Figures 14-16 Cussia lancettula Schrader

14,15 . DSDP 238-12, CC.

16. DSDP $238-23-2,75 \mathrm{~cm}$.

Figure 17 Gen. indet. species indet.; DSDP $238-7-5,40 \mathrm{~cm}$.

Figures 18, 19 Actinocyclus ehrenbergii Ralfs

18. DSDP 238-28-5, $75 \mathrm{~cm}$.

19. DSDP $238-23, \mathrm{CC}$.

Figures 20-25 Hemidiscus cuneiformis Wallich

20. DSDP $238-8-2,32 \mathrm{~cm}$.

21. DSDP $238-8-2,32 \mathrm{~cm}$.

22. DSDP $238-7-5,40 \mathrm{~cm}$.

23. DSDP 238-13-4, $75 \mathrm{~cm}$.

24. DSDP $238-7-5,40 \mathrm{~cm}$.

25. DSDP 238-4, CC. 
PLATE 19
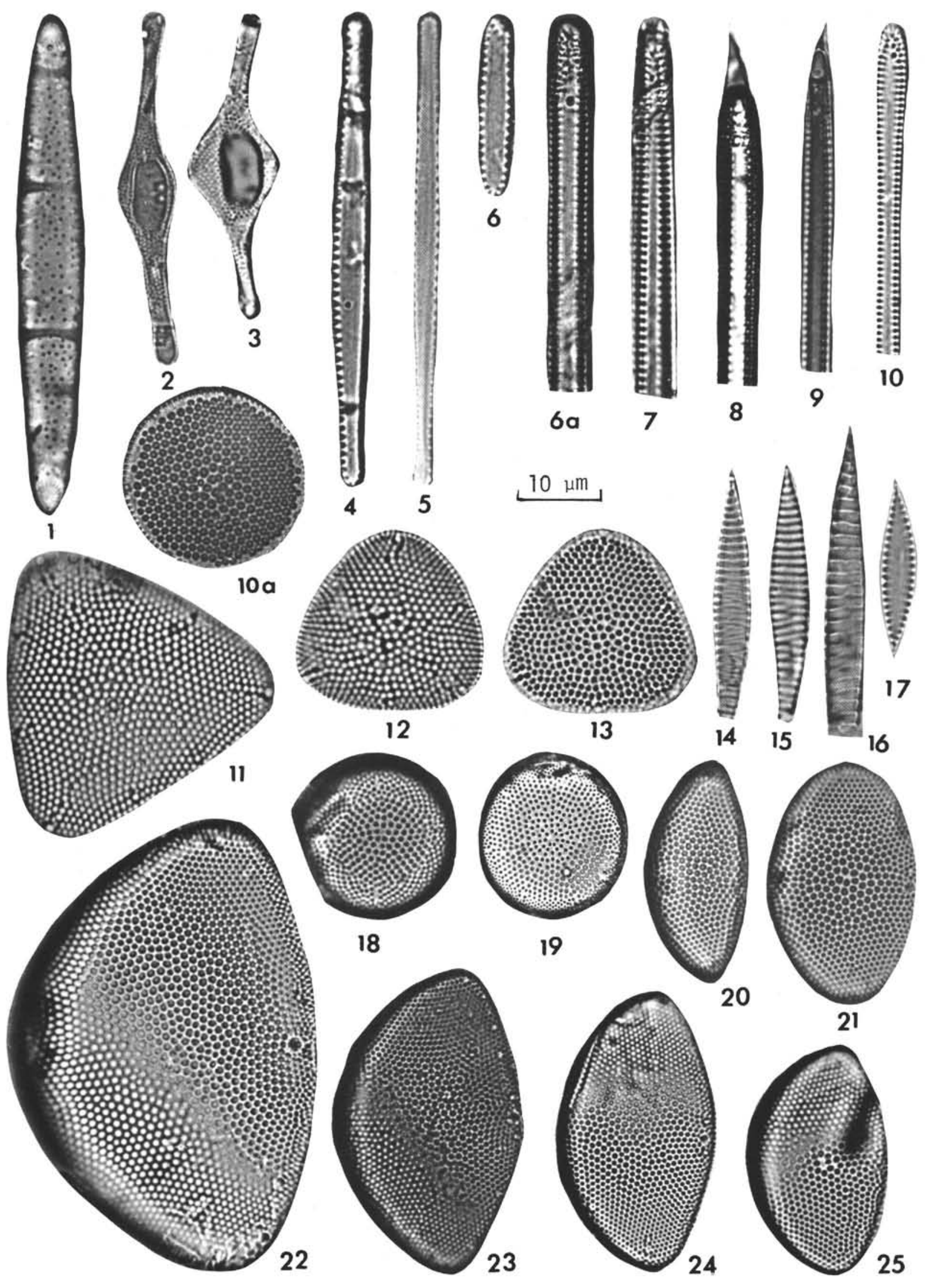
PLATE 20

(Magnification 1500X)

Figure 1 Actinocyclus ehrenbergii Ralfs var. tenella (Breb.) Hustedt; DSDP 238-1, CC.

Figure 2 Actinocyclus ehrenbergii Ralfs; DSDP 238-2-2, 75 $\mathrm{cm}$.

Figure 3 Actinocyclus ehrenbergii Ralfs var. tenella (Breb.) Hustedt; DSDP 238-1-4, $65 \mathrm{~cm}$.

Figure 4 Actinocyclus spec. 1 Schrader; DSDP 238-22, CC.

Figures 5-7 Triceratium cinnamomeum Grev. var. minor Grunow 5, 6. DSDP 238-3-2, $75 \mathrm{~cm}$.

7. DSDP $238-6-4,75 \mathrm{~cm}$.

Figure $8 \quad$ Triceratium cinnamomeum Grev.; DSDP 238-19-2, 75 $\mathrm{cm}$.

Figure 9 Triceratium cinnamomeum Grev. forma quadrangulata Grun.; DSDP 238-13-4, $75 \mathrm{~cm}$.

Figure 10 Triceratium cinnamomeum Grev. forma; DSDP $238-17-5,75 \mathrm{~cm}$.

Figure 11 Triceratium cinnamomeum Grev.; DSDP 238-1-4, 65 $\mathrm{cm}$.

Figures 12-15 Rouxia moholensis Schrader 12,13 . DSDP $238-29-5,75 \mathrm{~cm}$

14. DSDP $238-17-5,75 \mathrm{~cm}$. 15. DSDP $238-17-5,75 \mathrm{~cm}$.

Figure 16 Rouxia californica M. Peragallo; DSDP 238-23-2, 75 $\mathrm{cm}$. 
PLATE 20
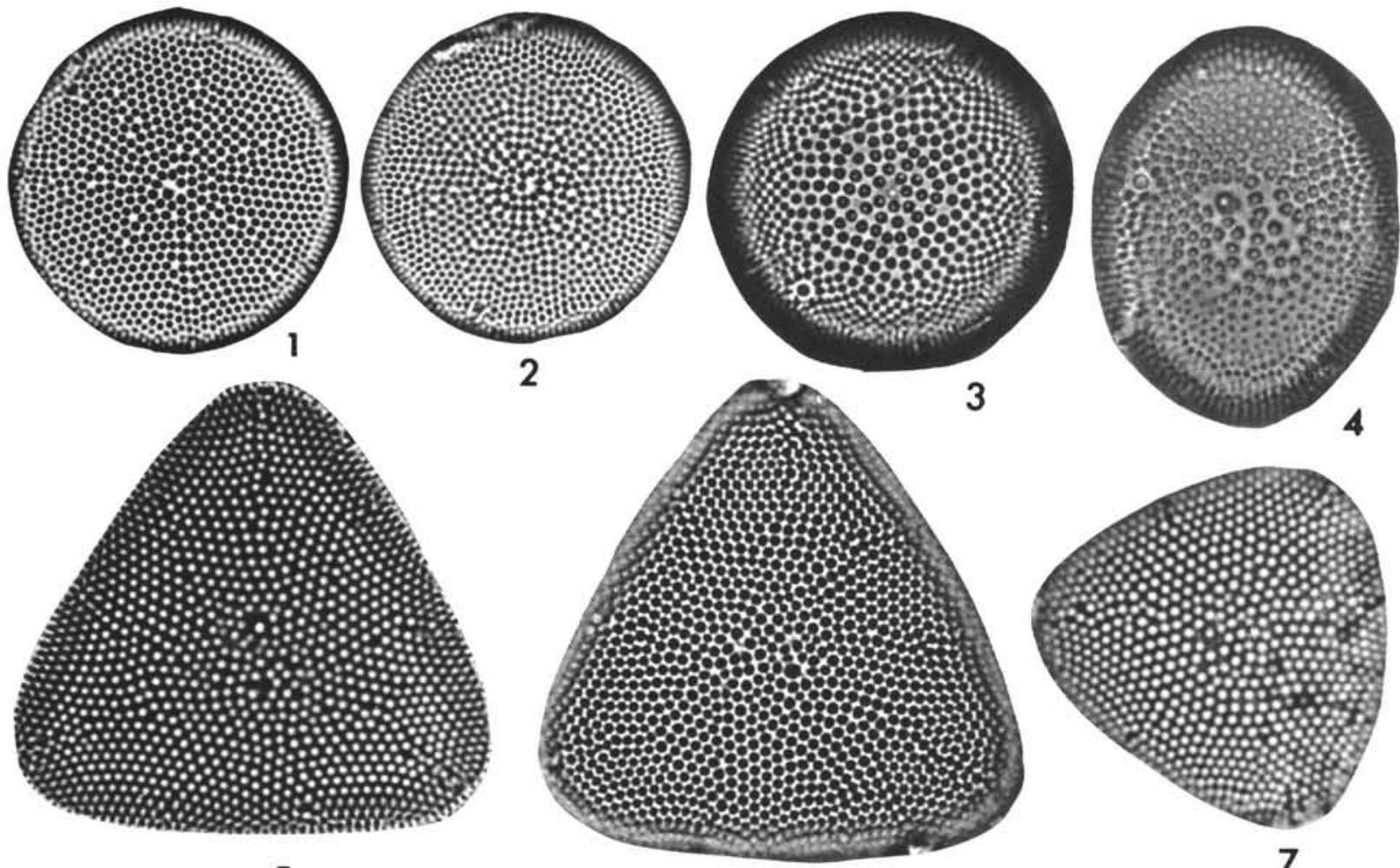

5

6
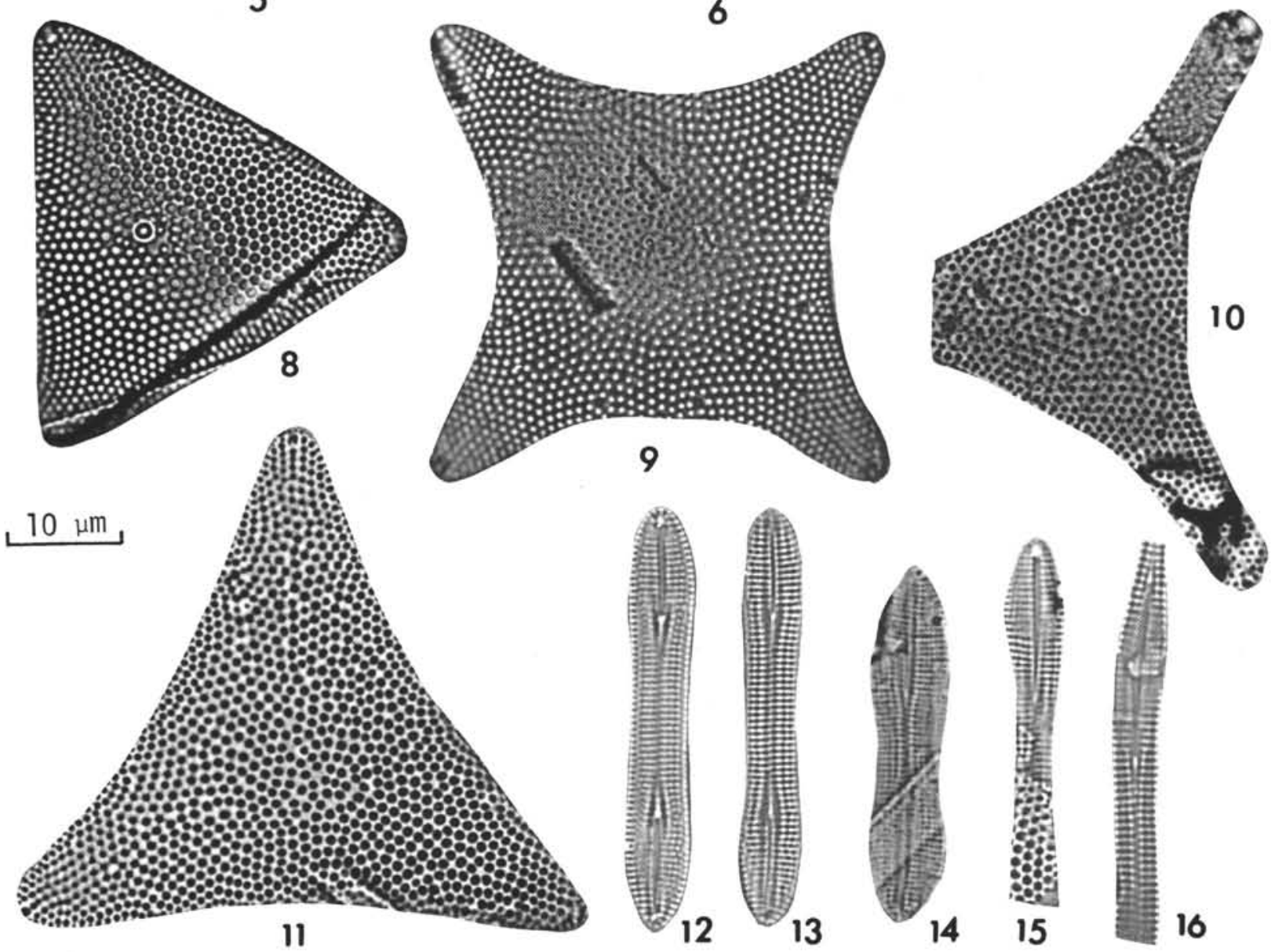
PLATE 21

(Magnification 1500X)

Figures 1, 2 Coscinodiscus plicatus Grunow; DSDP 238-6-1, 11 $\mathrm{cm}$.

Figures 3, 4 Coscinodiscus plicatus Group 4; DSDP 238-17-5, 75 $\mathrm{cm}$.

Figures 5-7 Coscinodiscus plicatus Grunow; DSDP 238-17-5, 75 $\mathrm{cm}$.

Figure 8 Coscinodiscus yabei Kanaya; DSDP 238-27-2, 125 $\mathrm{cm}$.

Figures 9-12 Roperia tesselata (Roper) Grunow

9. DSDP 238-3-1, $75 \mathrm{~cm}$.

10, 11. DSDP 238-1, CC.

12. DSDP $238-3-6,75 \mathrm{~cm}$.

Figures 13, 14 Roperia praetesselata $\mathrm{n}$. sp.; DSDP 238-13-3, $75 \mathrm{~cm}$.

Figure $15 \quad$ Roperia tesselata (Roper) Grunow; DSDP 238-4-5, 97 $\mathrm{cm}$.

Figures 16, 17 Actinocyclus ehrenbergii Ralfs 16. DSDP 238-13-3, $75 \mathrm{~cm}$. 17. DSDP $238-17-3,75 \mathrm{~cm}$.

Figure 18 Actinocyclus sp. 1 Schrader; DSDP 238-5-4, $90 \mathrm{~cm}$. 
PLATE 21
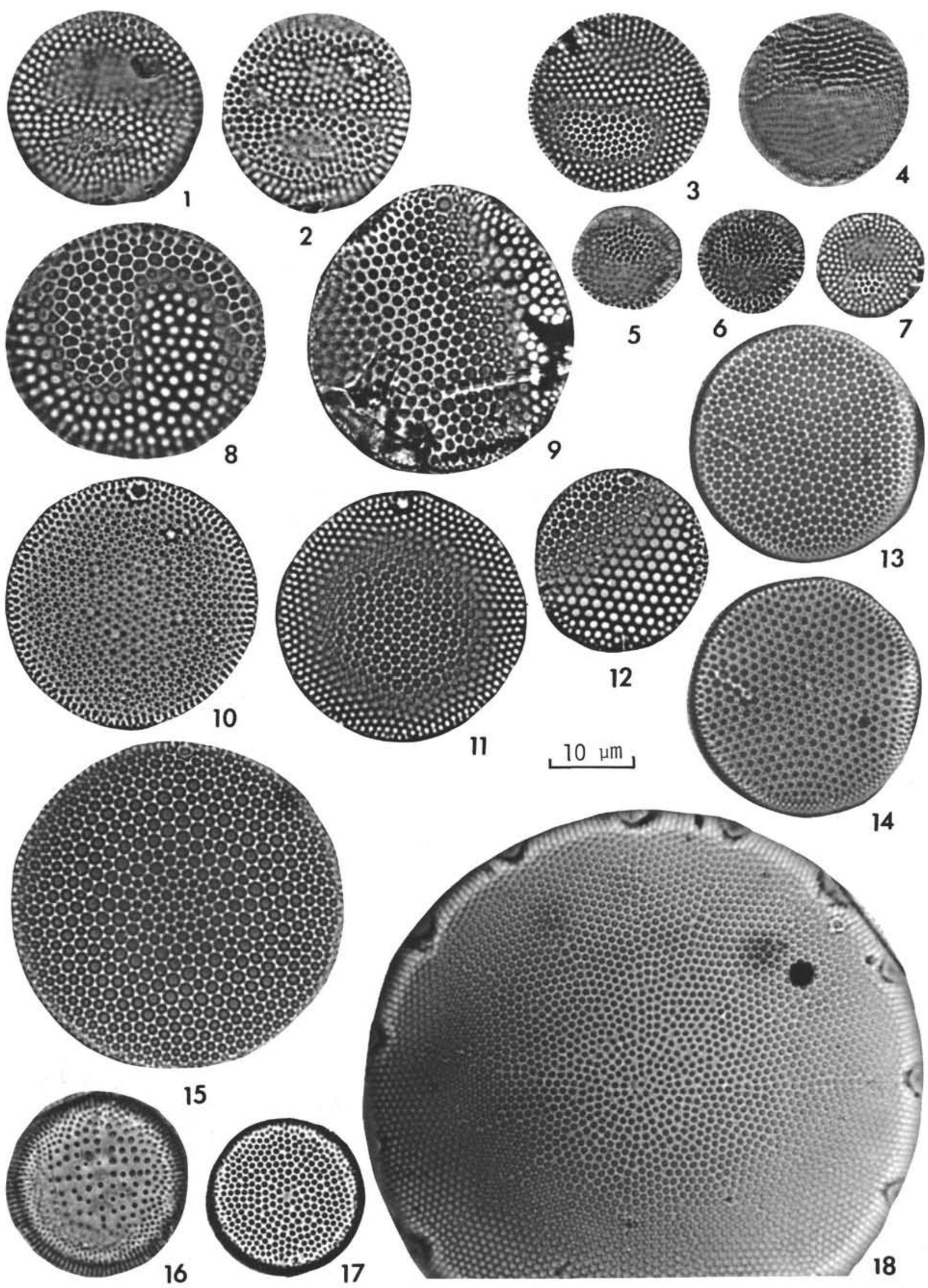

15
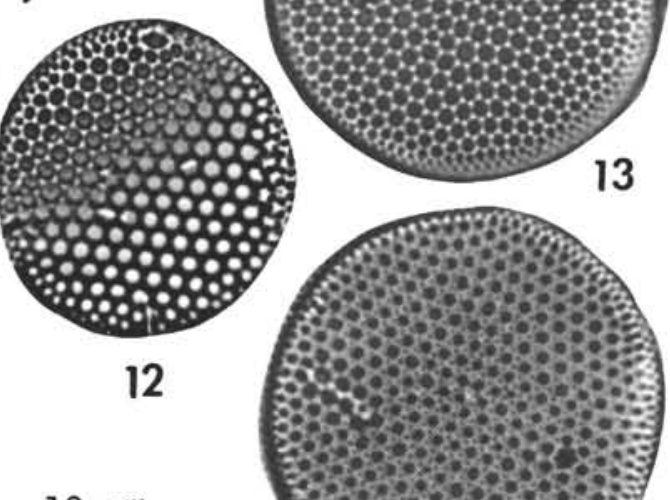

$10 \mu \mathrm{m}$
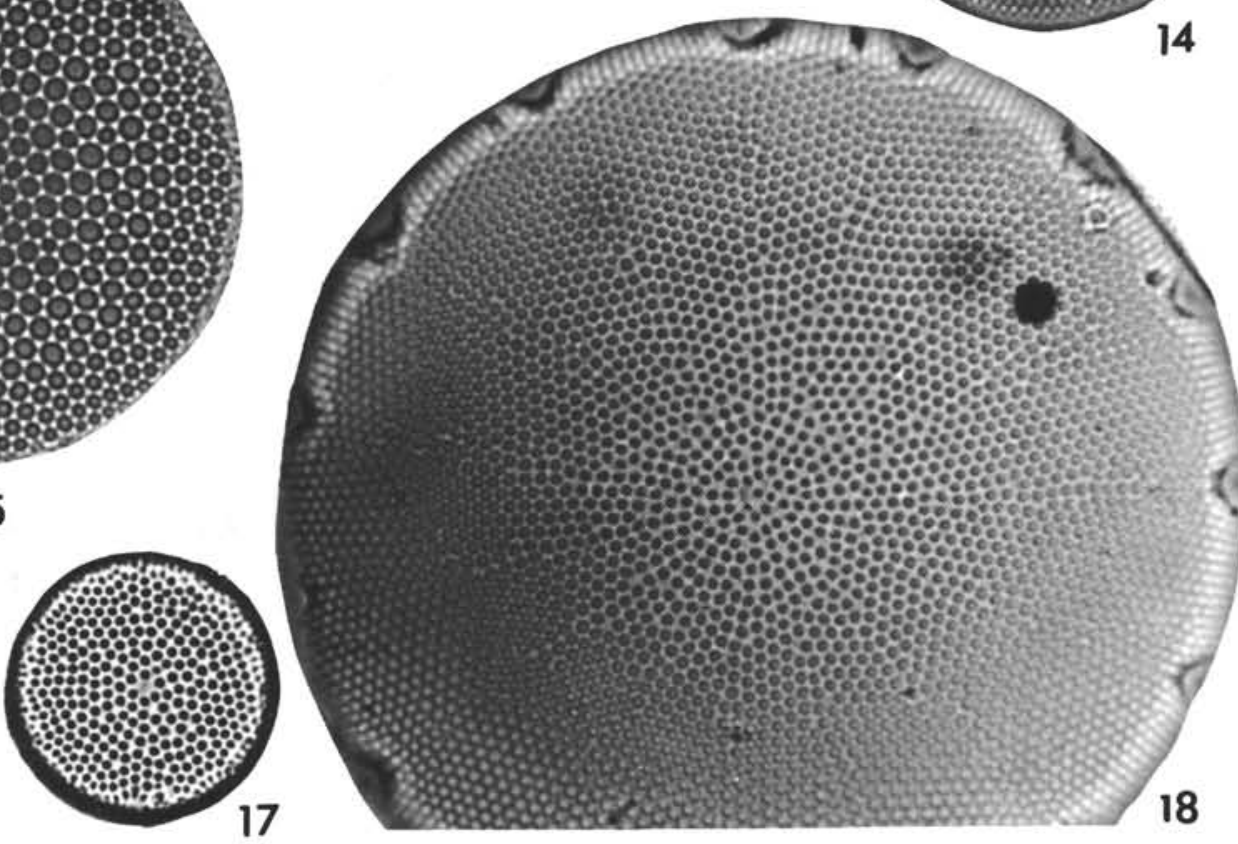
PLATE 22

(Magnification 1500X)

Figures 1-5 Thalassiosira miocenica n. $\mathrm{sp}$.

1-3. DSDP 238-19-2, $75 \mathrm{~cm}$.

4. DSDP 213-8-3, 50-51 cm (type).

5. DSDP 213-8-3, 50-51 cm (girdle).

Figures 6,7 Nitzschia miocenica Burckle; DSDP 213-8-3, 50-51 $\mathrm{cm}$.

Figures 8-10 Nitzschia porteri Frenguelli; DSDP 213-8-3, 50-51 $\mathrm{cm}$.

Figures 11-13 Thalassiosira miocenica $\mathrm{n}$. sp.; DSDP 213-8-3, 50-51 $\mathrm{cm}$.

Figure $14 \quad$ Pleurosigma spec.; DSDP 238-23-4, $75 \mathrm{~cm}$.

Figures 15, 16 Coscinodiscus nodulifer; DSDP 213-8-3, 50-51 cm.

Figure 17 Asteromphalus arachne; DSDP 213-8-3, 50-51 cm.

Figure 18 Trinacria regina Heib.; DSDP 238-34-4, $70 \mathrm{~cm}$.

Figure 19 Trinacria excavata Heib.; DSDP 238-34-4, $70 \mathrm{~cm}$.

Figure 20 Stephanopyxis turris (Grev. and Arn.) Ralfs.; DSDP $238-32-5,70 \mathrm{~cm}$. 
PLATE 22
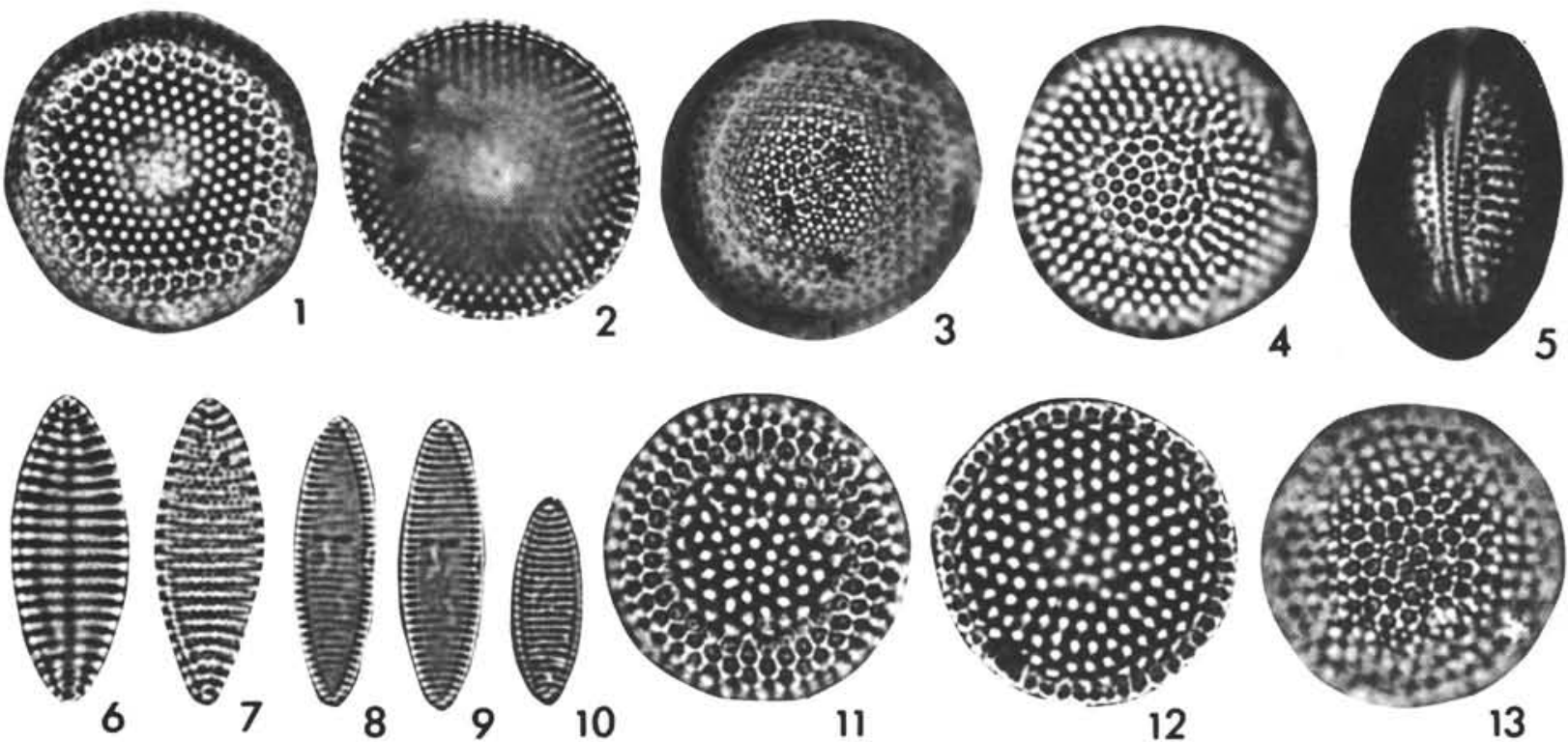

10
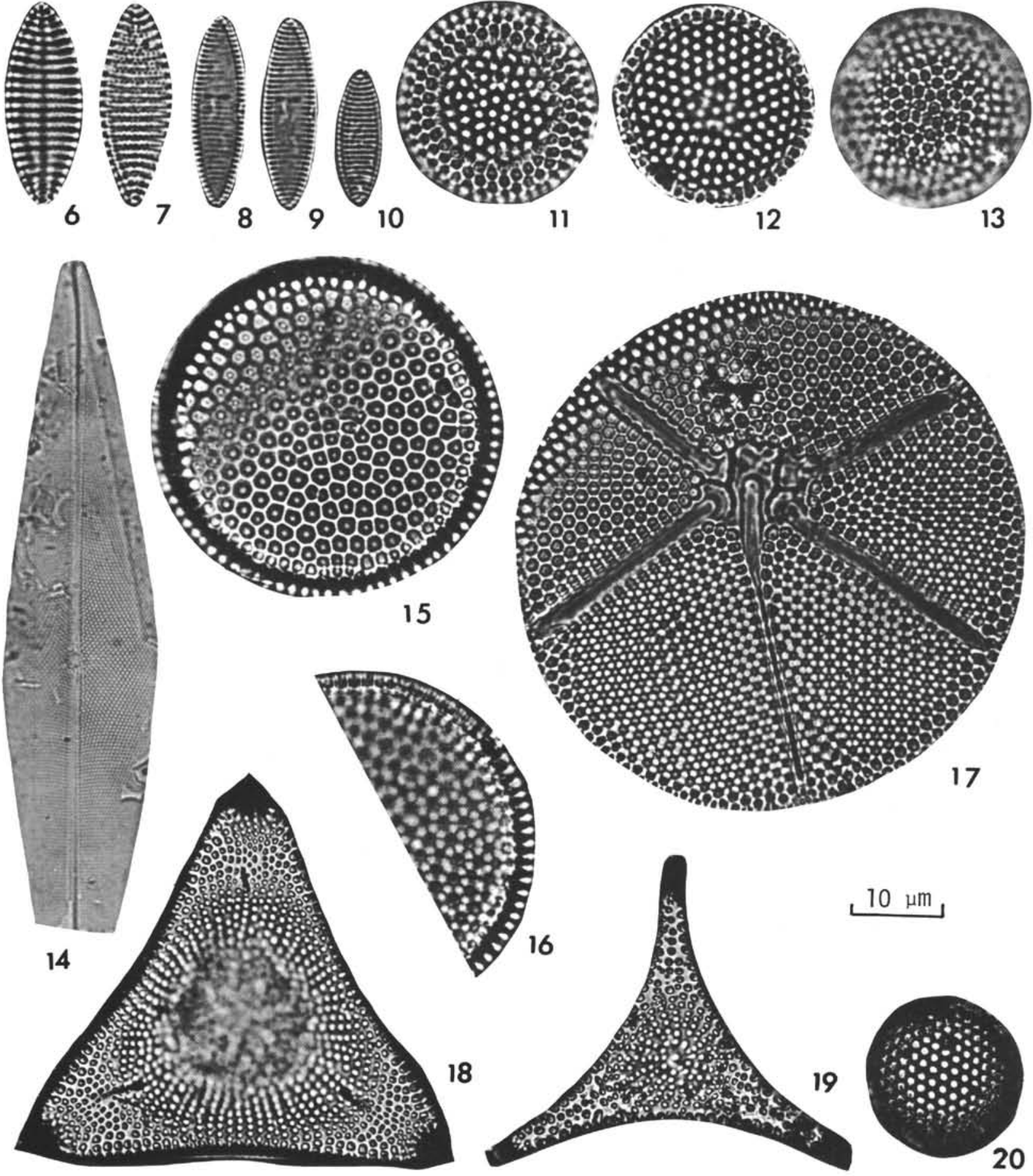